JOSÉ ROMEU GARCIA DO AMARAL

\title{
ENSAIO SOBRE O REGIME JURÍDICO DAS DEBÊNTURES
}

\author{
DISSERTAÇÃO DE MESTRADO \\ ORIENTADOR: PROF. DR. ERASMO VALLADÃO AZEVEDO E NOVAES \\ FRANÇA
}

FACULDADE DE DIREITO DA UNIVERSIDADE DE SÃO PAULO

SÃO PAULO 2014 


\section{ENSAIO SOBRE O REGIME JURÍDICO DAS DEBÊNTURES}

Dissertação apresentada como exigência parcial à obtenção do título de Mestre em Direito Comercial, no âmbito do Programa de Pós Graduação stricto sensu da Faculdade de Direito da Universidade de São Paulo, sob orientação do Prof. Dr. Erasmo Valladão Azevedo e Novaes França. 


\section{BANCA EXAMINADORA:}

Orientador:

Professor Dr. Erasmo Valladão Azevedo e Novaes França

Professor Arguidor:

Professor Arguidor: 
À Livia, com o meu eterno amor e carinho.

Aos meus queridos pais, Edmundo e Cláudia, por tudo, sempre, com muito amor.

Ao Professor Erasmo Valladão Azevedo e Novaes França, com a minha profunda gratidão, por tudo que aprendi e continuo a aprender. 


\section{AGRADECIMENTOS}

Agradeço aos Professores José Alexandre Tavares Guerreiro e Francisco Satiro de Souza Jr., que integraram a banca de qualificação, pelas valiosas observações e sugestões, bem como pelo incentivo à redação deste trabalho, o qual foi idealizado a partir das aulas do curso de Valores Mobiliários, ministrado na Pós-Graduação da Faculdade de Direito da Universidade de São Paulo, que tivemos a honra de participar como aluno de sua primeira turma.

Agradeço, também, aos Professores Nelson Eizirik e Flávia Parente pelas palavras de incentivo, quando esse projeto ainda era um sonho, bem como ao querido Edmur de Andrade Nunes Pereira Neto, cujo tema de sua dissertação de mestrado inspirou-me a escrever sobre a matéria aqui versada.

A todos os Colegas do IDSA, pela amizade, convívio e aprendizado contínuo, com a honra e o orgulho de participar desse think tank do direito societário brasileiro. Devo agradecer, especialmente, aos queridos amigos Rodrigo R. Monteiro de Castro, Luis André Negrelli de Moura Azevedo, Marcelo Guedes Nunes, Eduardo Caminati Anders, Plínio José Lopes Shiguematsu, Paulo Mattar Filho, Maristela Sabbag Abla Rossetti, Alex Prandini Júnior, Caesar Augustus Ferreira de Souza Rocha da Silva e Danilo Borges dos Santos Gomes de Araújo. Agradeço, ainda, ao André Grünspun Pitta pela amizade e valiosa contribuição à reflexão sobre a emissão de debêntures por sociedades limitadas.

Meus agradecimentos aos queridos amigos Walfrido Jorge Warde Júnior e Marcelo Godke Veiga, que me convidaram a participar da coordenação do curso de M\&A do Instituto Internacional de Ciências Sociais, bem como por tudo o mais que fizeram, sem medir esforços, e que não conseguiria listar nestas poucas linhas.

Agradeço, ainda, a todos os amigos e colegas da pós-graduação da USP, com quem tive a oportunidade de conviver durante as aulas, e muitas vezes além delas, em especial ao Luis Felipe Spinelli, João Pedro Scalzilli, Rodrigo Tellechea e Bruno di Dotto, os quais sempre foram companheiros e parceiros dessa empreitada. 
Meu carinho e gratidão ao Dr. Alfredo Felipe da Luz Sobrinho, que acreditou no meu desenvolvimento profissional, quando ainda era um recém advogado, incentivando os meus estudos e buscando sempre transmitir a sua vasta e rica experiência.

Por fim, agradeço eternamente a meu avô, José Garcia da Silva, in memorian, a quem devo as primeiras lições e ensinamentos sobre a vida e a prática do direito, sendo ele, também, responsável por apresentar-me às Arcadas. 


\section{RESUMO}

Este trabalho propõe-se a estudar, mediante abordagem teórica e prática, o regime jurídico das debêntures, tendo em vista as recentes alterações introduzidas pela Lei ${ }^{\circ} 12.431$, de 24 de junho de 2011, que promoveu mudanças significativas em sua disciplina, bem como examinar os problemas e questões atuais das debêntures em um contexto evolutivo da doutrina e dos casos práticos que lhe são submetidos à análise, tendo em vista o uso cada vez mais frequente desse mecanismo de financiamento das sociedades. Busca-se, também, examinar o funcionamento do mercado de debêntures e as novas propostas para incentivar a circulação dos títulos de dívida. Dentre as questões mais controvertidas a serem estudadas neste trabalho, destacam-se as seguintes: (i) evolução da natureza jurídica do instituto, em que as debêntures são vistas como títulos de dívida pertencentes à categoria dos valores mobiliários; (ii) criação do novo mercado de debêntures, como avanço à proposta do Novo Mercado de Renda Fixa; (iii) possibilidade de emissão de debêntures por sociedades limitadas e cooperativas, em razão da ausência de vedação legal e da existência de normas que lhe dão suporte jurídico; (iv) realização de negócios jurídicos com debêntures que vão além da sua função econômica de financiamento da empresa; (v) existência da organização dos debenturistas, em complemento à ideia de comunhão de interesses, tendo em vista o seu caráter orgânico; e, por fim, (vi) se os deveres fiduciários dos administradores se voltariam também aos interesses dos debenturistas, como credores especiais da sociedade emitente.

Palavras-chaves: debêntures - tutela dos debenturistas - negócios estruturados com debêntures - mercado de debêntures - novo mercado de renda fixa - novo mercado de dívida - emissão de debêntures por sociedades limitadas ou cooperativas - empréstimo de debêntures - recolocação de debêntures conversíveis - organização dos debenturistas - posição de debenturista - deveres fiduciários em face dos debenturistas - agente fiduciário - assembleia de debenturistas. 


\begin{abstract}
This work aims to study, through a theoretical and practical approach, the legal system of debentures in view of the recent changes introduced by Law No. 1431, of June 24, 2011, affecting significantly their discipline, and also to examine their current problems and issues within the evolutionary context of the doctrine and the case studies that are submitted to analysis, since the use of this financing mechanism by companies has been increasingly frequent. It also seeks to examine the functioning of the debenture market and the new proposals to stimulate the circulation of debt bonds. Amongst the most controversial issues to be studied in this work, the following are highlighted: (i) the evolution of the legal nature of this institute, in which debentures are seen as debt notes pertaining to the category of securities; (ii) the creation of a new debenture market as an advancement to the proposal of the New Fixed Income Market; (iii) the possibility of limited partnerships and cooperatives issuing debentures in view of the absence of a legal prohibition and the existence of norms that give legal support to it; (iv) the consummation of legal transactions with debentures that go beyond their economic function of business financing; (v) the existence of a debenture holder organization as a complement to the idea of pooling of interests, in view of its organic character; and, finally, (vi) whether the fiduciary duties of the administrators would also accommodate the interests of the debenture holders, while in their position of special creditors to the issuing business.
\end{abstract}

Key-words: debentures - protection of debenture holders - structured transactions with debentures - debenture market - new fixed income market - new debt market - issuance of debentures by limited liability companies or cooperatives - debenture loans - replacement of convertible debentures - organization of debenture holders - debenture holder position fiduciary duties in relation to debenture holders - fiduciary agent - general meeting of debenture holders. 


\section{SUMÁRIO}

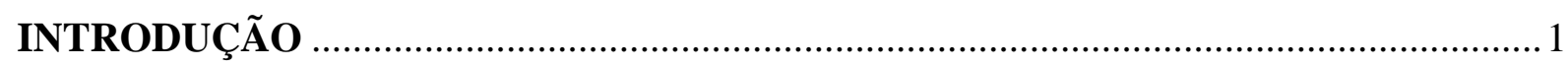

CAPÍTULO I - NOÇÕES INTRODUTÓRIAS SOBRE O REGIME JURÍDICO .............6

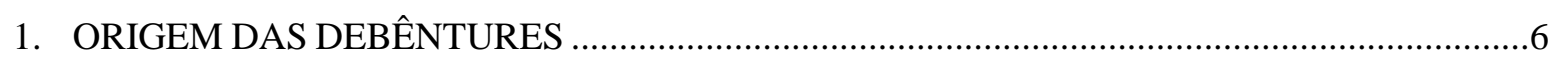

2. EVOLUÇÃO HISTÓRICO-NORMATIVA NO DIREITO BRASILEIRO ................................10

3. NOTAS SOBRE DEBÊNTURES NO DIREITO COMPARADO …..........................................18

3.1. As debêntures no direito anglo-saxão (debentures ou bonds) ...........................................18

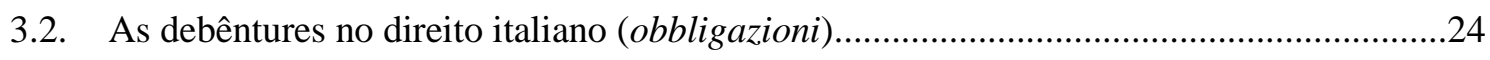

3.3. As debêntures no direito francês (obligations) ……….....................................................29

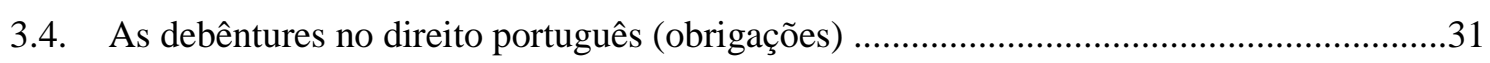

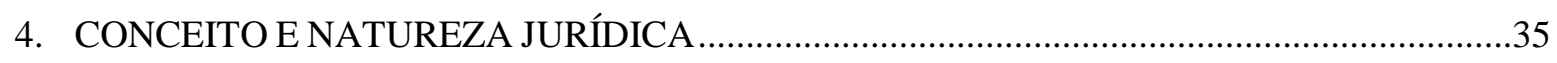

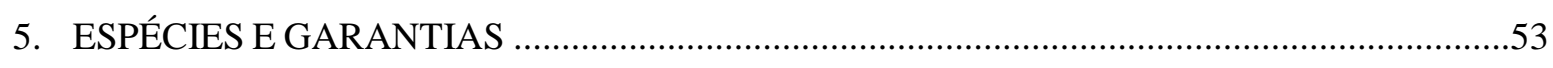

6. COMPARAÇÃO ENTRE AS DEBÊNTURES E OUTROS VALORES MOBILIÁRIOS DE

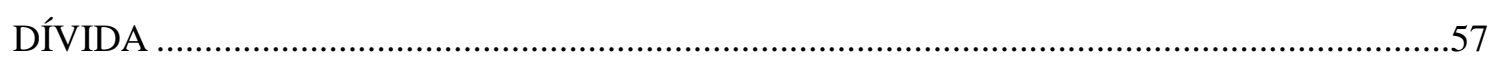

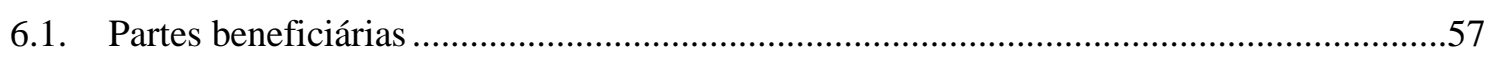

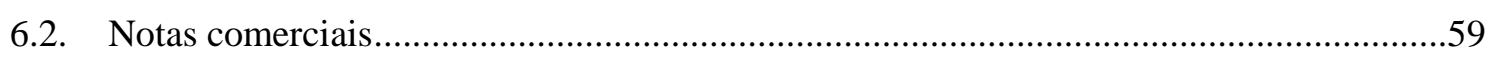

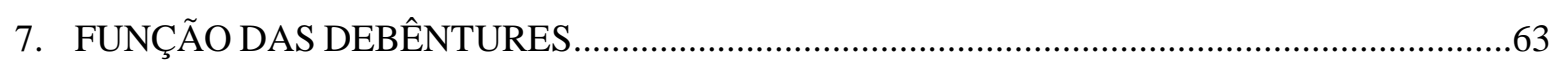

8. CRIAÇÃO, EMISSÃO, COLOCAÇÃO E CIRCULAÇÃO: CONCEITOS E IMPLICAÇÕES

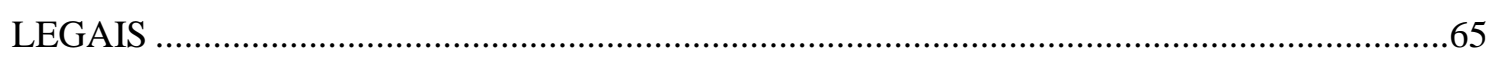

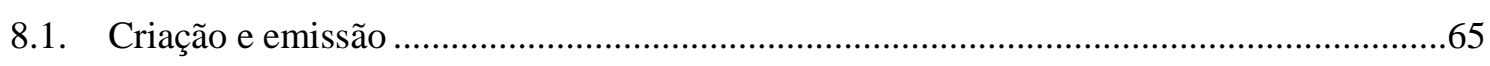

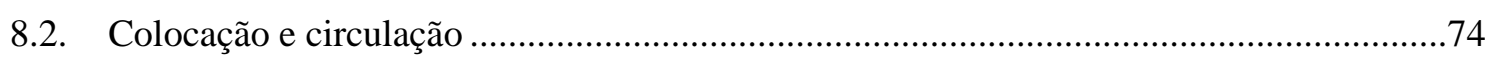

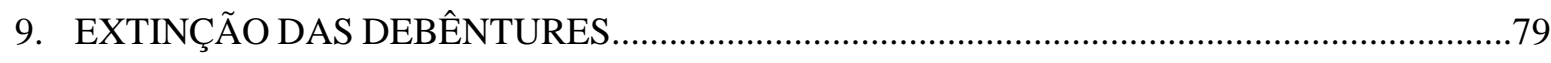

CAPÍTULO II - ALTERAÇÕES DO REGIME PELA LEI No 12.431/2011 ................... 87

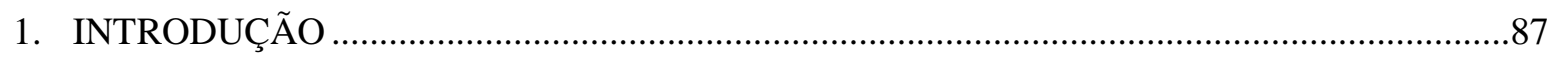

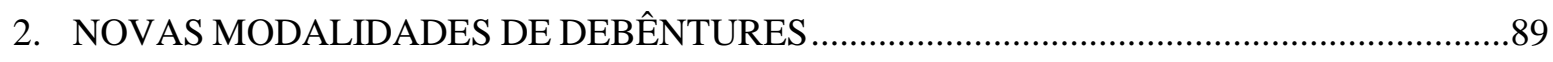

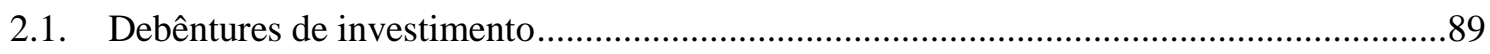

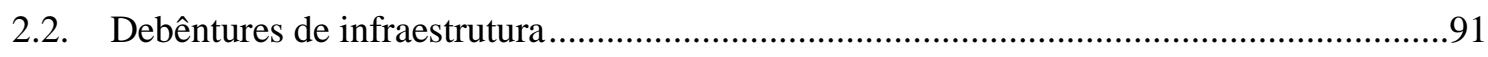

3. APERFEIÇOAMENTO DAS REGRAS DE AMORTIZAÇÃO E RESGATE PARCIAL ..........94

4. NOVAS REGRAS SOBRE AQUISIÇÃO PELA COMPANHIA DE DEBÊNTURES DE SUA PRÓPRIA EMISSÃO

5. A EMISSÃO DE DEBÊNTURES POR DELIBERAÇÃO DO CONSELHO DE ADMINISTRAÇÃO

6. PARTICIPAÇÃO DO AGENTE FIDUCIÁRIO EM MAIS DE UMA EMISSÃO DA MESMA COMPANHIA 


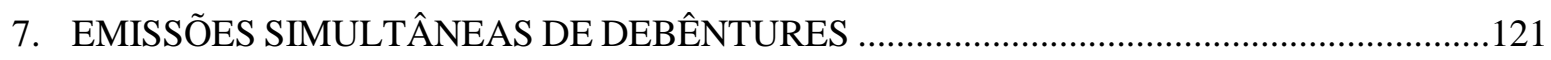

8. REVOGAÇÃO DOS LIMITES LEGAIS DE EMISSÃO .........................................................124

CAPÍTULO III - MERCADO DE DEBÊNTURES................................................... 129

1. FUNCIONAMENTO DO MERCADO DE DEBÊNTURES NO BRASIL ................................129

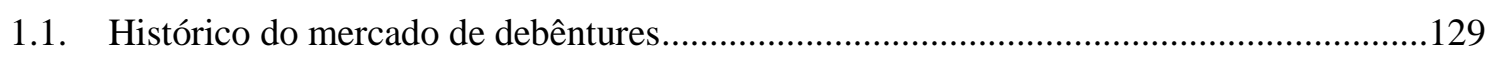

1.2. Sistemas de registro, custódia, compensação e liquidação de debêntures .........................132

1.3. Proposta do Novo Mercado de Renda Fixa ..................................................................137

\section{CAPÍTULO IV - PROBLEMAS E QUESTÕES ATUAIS DAS DEBÊNTURES ......... 142}

1. EMISSÃO DE DEBÊNTURES POR SOCIEDADES LIMITADAS E COOPERATIVAS .......142

1.1. Emissão de debêntures por sociedades empresárias limitadas ......................................149

1.2. Emissão de debêntures por sociedades cooperativas ........................................................167

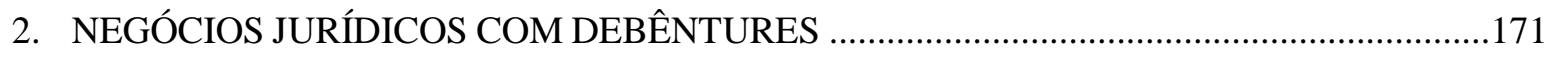

2.1. Empréstimo de debêntures e sua natureza de negócio fiduciário .....................................171

2.2. Recolocação de debêntures conversíveis e o direito de preferência ..................................180

2.3. Debêntures como medida defensiva à tentativa de oferta hostil .......................................182

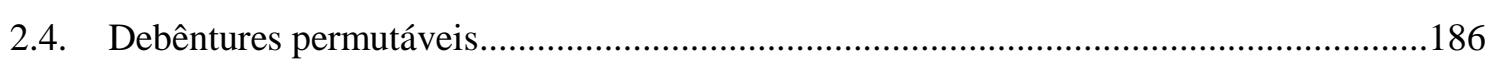

2.5. Uso das debêntures para dação em pagamento de nova emissão ....................................189

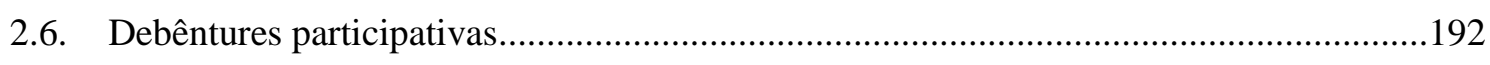

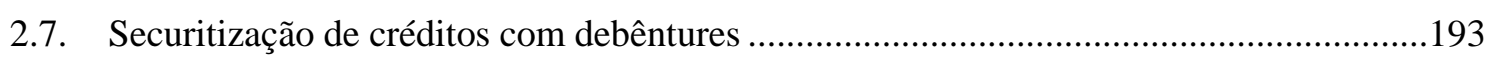

2.8. Outros negócios estruturados com debêntures..................................................................194

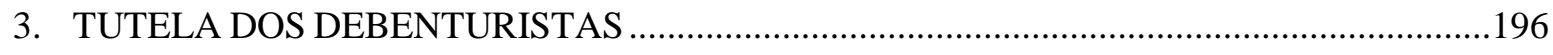

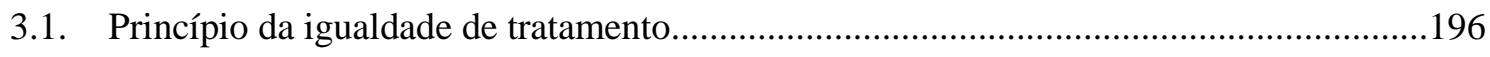

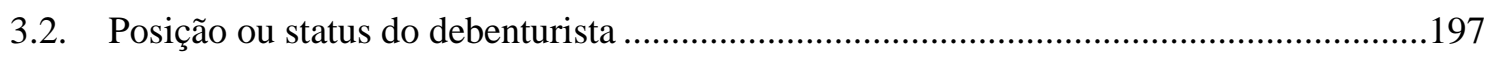

3.3. Organização ou comunhão dos debenturistas e sua estrutura orgânica .............................200

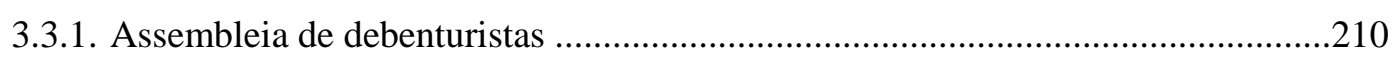

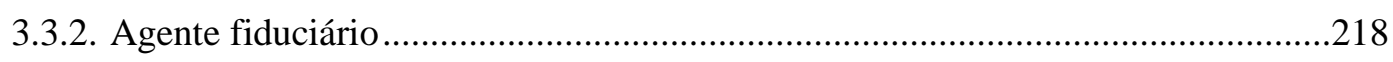

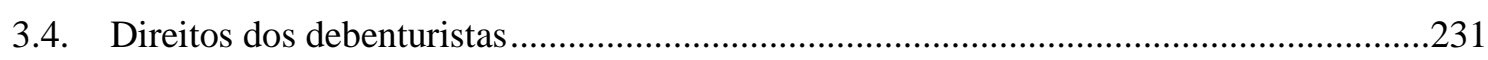

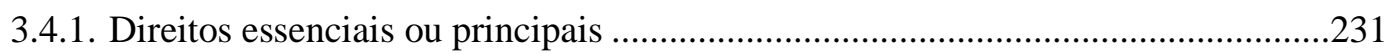

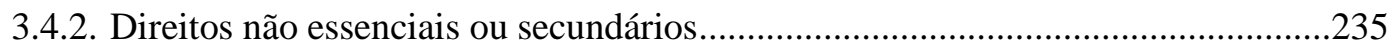

3.5. Deveres dos administradores em face dos debenturistas .................................................236

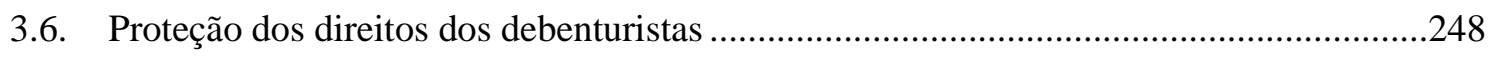

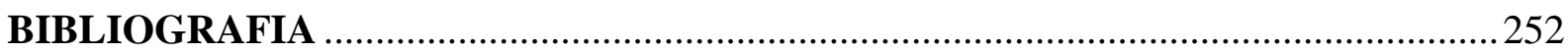




\title{
INTRODUÇÃO
}

\begin{abstract}
"The 'law merchant', as Chief Justice Cockburn pointed out in his instructive judgment in Goodwin v. Robarts, is not fixed and stereotyped, but a living law, capable of expansion and enlargement to meet the requirements of trade in the varying circumstances of commerce; and no more striking object-lesson in ilustration of this truth could be found than debentures and debenture stock."
\end{abstract}

As sociedades dependem de recursos para o desenvolvimento de suas atividades, tendo os acionistas e os credores como fontes de captação externas, por meio de capitalização ou securitização, respectivamente. $^{2}$

A capitalização ocorre por meio de realização das entradas, com a integralização do capital inicial no ato de constituição da sociedade (originária), ou nos casos de aumento de capital, em que há nova integralização (secundária), atribuindo-se, nestes casos, a posição de sócio, mediante subscrição de um título patrimonial.

Têm-se duas espécies de capitalização secundária na sociedade anônima: (i) capitalização com o ingresso de novos recursos (art. 170, LSA), provenientes dos atuais sócios ou de novos subscritores que participam de aumento de capital; (ii) autocapitalização, mediante aumento de capital com o aproveitamento de lucros e reservas (art. 169, LSA).

Os credores, por sua vez, participam do financiamento de uma determinada sociedade por meio de securitização, isto é, a contratação de instrumentos financeiros de diferentes modalidades (empréstimos, notas promissórias, debêntures, etc.) e características (curto, médio ou longo prazo; com ou sem garantia; etc.), que podem ou não ser reconhecidos em lei como valores mobiliários.

\footnotetext{
${ }^{1}$ MANSON, Edward. The Debentures and Debenture Stock of Trading and Other Companies. $2^{\mathrm{a}}$ ed. Londres: Butterworth \& Co., 1910, prefácio, p. iii.

${ }^{2}$ Edmur de Andrade Nunes Pereira Neto define como "meios internos ou próprios" a obtenção de recursos junto aos sócios e como "meios externos" o financiamento da sociedade por meio de créditos contraídos junto a terceiros, que, em tese, não participariam do capital da sociedade. Edmur anota, ainda, que as operações de financiamento poderiam ser divididas em duas categorias: "operações que apontam fundos com vínculo de capital; e operações que apontam fundos com vínculo de crédito." (Aspectos Jurídicos da Emissão de Debêntures Conversíveis em Ações. Dissertação de Mestrado apresentada à Faculdade de Direito da Universidade de São Paulo. 1986, pp. 8-9).
} 
Tais instrumentos financeiros, reveladores de um título de dívida, são inscritos no passivo e atribuem ao credor posição distinta daquela conferida ao sócio, com algumas exceções (p. ex.: direito de participar dos $\operatorname{lucros}^{3}$ nas partes beneficiárias ou nas debêntures participativas). ${ }^{4}$

“O financiamento da empresa é, portanto, a colocação à sua disposição, da totalidade do capital de que necessita e pode ser concebido, em abstrato, como o resultado do encontro das exigências da empresa com as do capital". 5 A sociedade busca as condições mais vantajosas para financiar a sua atividade, compatibilizando-as com as "tendências" ou expectativas do mercado financeiro, que as analisa e pondera sobre a aplicação do investimento a crédito em um determinado valor mobiliário ou título de dívida.

A doutrina estrangeira reconhece que o "empréstimo obrigacionista [ou debenturístico] é um financiamento, em regra de montante substancial, que a sociedade contrai junto de diversas entidades" ${ }^{\prime 6}$, sendo que o rendimento e os direitos conferidos pelo valor mobiliário devem estar claramente definidos em lei ou na escritura de emissão.

A posição de credor, como dito acima, difere daquela atribuída ao sócio, pois, via de regra, particularmente nos instrumentos de dívida contratados junto a instituições financeiras, o credor não tem direito de participar ou votar nas assembleias ou reuniões de sócios, não indica ou elege membros do conselho de administração ou do conselho fiscal, por conseguinte, em tese, tem pouca influência ${ }^{7}$ direta sobre os negócios sociais.

\footnotetext{
${ }^{3} \mathrm{O}$ art. 56 da LSA estabelece que "a debênture poderá assegurar ao seu titular juros, fixos ou variáveis, participação no lucro da companhia e prêmio de reembolso."

4 "As obrigações [ou debêntures] são geralmente contrapostas às acções, na medida em que, na perspectiva da sociedade emitente, representam dívida, a qual, em princípio, vencerá juros e deve ser reembolsada. O direito ao pagamento do juro e ao reembolso são, assim, os dois direitos principais que definem a situação jurídica do obrigacionista." (Código das Sociedades Comerciais Anotado. Coord.: CORDEIRO, António Menezes. $2^{\mathrm{a}}$ ed. Coimbra: Almedina, 2012, p. 931).

${ }^{5}$ Edmur de Andrade Nunes Pereira Neto, ob. cit., p. 9.

${ }^{6}$ CUNHA, Paulo Olavo. Direito das Sociedades Comerciais. $5^{\mathrm{a}}$ ed. Coimbra: Almedina, 2012, p. 825.

${ }^{7}$ Ressalva-se aqui a possibilidade de controle externo ou exercício de influência dominante pelos credores, certamente de maneira indireta. Fábio Konder Comparato (em co-autoria com Calixo Salomão Filho) afirma o seguinte: "Uma situação clássica de controle externo, oriunda do endividamento social, é a que deriva da emissão de debêntures. Tratando-se de crédito privilegiado e geralmente de montante elevado, a operação debenturística pode tornar a companhia emitente subordinada à influência dominante da massa de debenturistas, notadamente quando precária a situação financeira da devedora" (Poder de Controle na Sociedade Anônima. $5^{\mathrm{a}}$ ed. Rio de Janeiro: Forense, 2008, p. 92).
} 
Por outro lado, alguns títulos de dívida, como as debêntures, atribuem certos direitos aos credores, por exemplo, o direito de conversão em ações (naquelas conversíveis) e o direito de participar de assembleia de debenturistas, que os colocam em destaque frente a um contrato de empréstimo firmado com uma instituição financeira. ${ }^{8}$

Isto ocorre, pois, em se tratando de títulos de dívida emitidos em série, ou massificados, como já os classificou a doutrina comercialista, a relação jurídica é formada entre uma sociedade emissora e diversos credores que subscrevem o título e passam a compor a comunhão de debenturistas. Nítida é a distinção entre o negócio realizado por uma sociedade que necessita de crédito e vai buscá-lo junto a uma determinada instituição financeira, formando uma relação jurídica bilateral, e o negócio jurídico de emissão em série de um título de dívida, subscrito e integralizado por uma massa até então desconhecida de credores, que passam a formar a relação jurídica protegida pelas normas de direito societário, de mercado de capitais e de valores mobiliários e, também, pelas regras contidas na escritura de emissão.

Ainda, o instrumento de empréstimo firmado com instituição financeira não admite livre circulação ou transferência, sem anuência do credor $^{9}$, diferentemente dos títulos de dívida como as debêntures, partes beneficiárias e notas comerciais, que a admitem, posto que se sujeitam ao princípio da livre circulação.

Como títulos de dívidas emitidos em série, as debêntures têm sido utilizadas, com frequência, para a captação de recursos pelas sociedades anônimas, superando em alguns

\footnotetext{
${ }^{8}$ Em matéria de direitos emanados dos títulos de dívida, a doutrina portuguesa explica que "a título secundário, são conferidos aos obrigacionistas [debenturistas] outros direitos, quer por imperativo legal, quer por iniciativa da entidade emitente. No primeiro caso está o direito à informação, através do representante comum" (que no Brasil recai sobre a figura do agente fiduciário). "No segundo caso estarão a concessão de garantias especiais ou a atribuição dos direitos de subscrever acções ou de converter as obrigações em acções, como sucede com a criação dos títulos mistos" (Menezes Cordeiro, ob. cit., p. 931). A exemplo disso, também, tem-se no direito brasileiro a possibilidade de se atribuir bônus de subscrição, como vantagem adicional, aos titulares de debêntures (art. 77 da LSA).

9 "O direito romano considerava o crédito intimamente ligado à pessoa do credor. Os jurisconsultos não admitiam que o direito creditório pudesse transferir-se diretamente da pessoa que o constituía em seu favor para um terceiro, porque a obbligatio importava em uma relação de direito entre pessoas determinadas. Para que se desse a mudança na pessoa do credor, ou na do devedor, era forçoso que uma nova estipulação interviesse entre as partes primitivamente contratantes." (SOUZA, H. Inglez. Titulos ao Portador no Direito Brazileiro. Rio de Janeiro: Livraria de Francisco Alves, 1898, p. 5/6)
} 
anos até mesmo a emissão de ações ${ }^{10}$. Recentemente, com a queda das taxas de juros, a necessidade de financiamento para projetos de infraestrutura, os incentivos de natureza fiscal e a busca de investimentos rentáveis, as debêntures surgem como importante instrumento de consolidação do mercado financeiro e de capitais, deslocando parcela relevante dos recursos para o mercado de dívida e fomentando a economia nacional.

A correlação entre o aumento da emissão de debêntures e o desenvolvimento econômico foi objeto de estudo elaborado por Renê Coppe Pimentel, Edna Ferreira Peres e Gerlando Augusto Sampaio Franco de Lima ${ }^{11}$, em que se verificou aumento das colocações do título no mercado durante o período de estabilização da economia brasileira (chamado Plano Real) e crescimento econômico atrelado à ampliação da oferta do referido valor mobiliário.

Mais recentemente, a Lei $\mathrm{n}^{\circ} 12.431$, de 24 de junho de 2011, alterou o regime jurídico das debêntures, introduzindo mudanças significativas na disciplina prevista na Lei ${ }^{\circ}$ 6.404/76, o que levou à desatualização de alguns estudos específicos sobre a matéria, exigindo o esforço de atualização de tais estudos.

Diante de tal cenário evolutivo e da necessidade de sua atualização, bem como considerando a nova realidade do mercado de dívida brasileiro, apresentamos o presente ensaio sobre o regime jurídico das debêntures, com o objetivo de lançar luz sobre o tema e trazer à tona as questões controvertidas a ele inerentes.

Pretende-se discorrer brevemente sobre noções introdutórias e gerais, que servirão para os estudos posteriores que se seguirão. Trataremos, também, das recentes alterações introduzidas no regime das debêntures, abordando todos os itens objeto de atualização, bem como enfrentaremos os problemas e questões atuais das debêntures. Entre os temas atuais, abordaremos a emissão de debêntures por sociedades limitadas e outros tipos

\footnotetext{
${ }^{10}$ Em 2006, 2011 e 2012, o volume de emissões primárias e secundárias de debêntures superou o volume de ações emitidas, segundo dados da ANBIMA, conforme tabela comparativa disponível no site: http://www.debentures.com.br/dadosconsolidados/comparativovaloresmobiliarios.asp. Acesso em: 30/09/2013. ${ }^{11} O$ mercado de Debêntures e o Financiamento Produtivo no Brasil: uma Análise de Cointegração e Causalidade. Revista de Contabilidade e Organizações, da Faculdade de Economia, Administração e Contabilidade da Universidade de São Paulo. Vol. 5. N. 11, Ano 2011, p. 4-22. Disponível em: www.rco.usp.br/index.php/rco/article/download/155/190. Acesso em: 21/08/2013.
} 
societários, bem como as medidas já adotadas para o desenvolvimento de um novo mercado de dívida, visando estimular a liquidez das debêntures.

Ainda, o presente ensaio tem por objetivo discorrer sobre os negócios jurídicos realizados com debêntures, como a aquisição pela própria companhia emissora para mantença em tesouraria, a negociação com debêntures, operações societárias que utilizam as debêntures como veículo para a aquisição de controle, as debêntures como poison pill, etc. Por fim, cuidaremos da tutela dos debenturistas e das questões relacionadas à atuação do agente fiduciário.

Espera-se, com isso, oferecer uma pequena contribuição ao estudo das debêntures, que possa ser útil como instrumento consolidador dos trabalhos já elaborados sobre o tema, servindo, ainda, como fonte de consulta àqueles que atuam no mercado de dívida e enfrentam os desafios diuturnos de consolidação do instituto como ferramenta de financiamento da empresa. 


\section{CAPÍTULO I - NOÇÕES INTRODUTÓRIAS SOBRE O REGIME JURÍDICO}

\section{ORIGEM DAS DEBÊNTURES}

As primeiras características do empréstimo debenturístico surgiram na Idade Média. Criava-se, desde então, uma obrigação do Estado em favor daqueles indivíduos que contribuíssem para o financiamento de empreendimentos públicos, evitando o aumento de impostos e buscando recursos junto ao público para as mais diversas finalidades ${ }^{12}$. A doutrina ${ }^{13}$ cita a emissão de empréstimos pela República de Gênova, já a partir do Século XII, bem como o seu fracionamento e a formação da primeira organização de obrigacionistas, com a criação da Casa delle compere e dei banchi di San Giorgio ${ }^{14}$.

A Casa de San Giorgio administrava a dívida pública da república genovesa, cuja atividade deu origem à própria instituição e era gerida pelo núcleo chamado "le compere" - o termo "compera" tem suas raízes no mercado financeiro genovês do Século XII. Para que a receita dos impostos fosse menos incerta, realizava-se uma operação em que o Estado vendia ao particular, por meio de contrato direto ou leilão público, o direito de cobrar um determinado imposto especial, por um determinado período, ajustando-se o pagamento, pelo particular ao Estado, em prestações periódicas, com garantias adequadas, tornando o fluxo de receitas do Estado regular e previsível e transferindo o risco para o particular, que ficava responsável pela cobrança dos impostos. ${ }^{15}$

\footnotetext{
12 “'Anche in passato, nella vita degli stati il debito pubblico costituiva la via di uscita preferita da un'emergenza dispendiosa, fosse costituita da guerre, carestie, epidemie, cataclismi naturali. Se voleva evitare una gravosa ed impopolare imposta patrimoniale, solo con un prestito lo stato poteva superare i limiti del bilancio ordinario e procurarsi una massa supplementare di denaro adeguata alle necessità. La gamma tipologica dei prestiti pubblici era molto estesa e variava a seconda degli accordi raggiunti dallo stato debitore e dai privati creditori per conciliare le rispettive esigenze. Le variabili che sottostavano (allora come oggi) alle diverse forme del debito pubblico erano essenzialmente tre: il termine del rimborso, la rimunerazione del capitale o interesse e le garanzie offerte dallo stato per il pagamento degli interessi e l'eventuale rimborso del capitale" (FELLONI, Giuseppe. La Casa delle Compere e dei Banchi di San Giorgio. Debito Pubblico. Disponível em: http://www.lacasadisangiorgio.it/main.php?do=node\&tag=4. Acesso em: 28/08/2013).

${ }^{13}$ Cf. BORBA, José Edwaldo Tavares. Das Debêntures. Rio de Janeiro: Renovar, 2005, p. 2.

${ }^{14} \mathrm{Cf}$. a história da Casa delle compere e dei banchi di San Giorgio, cujo funcionamento operou-se entre 1407 e 1805. Disponível em: http://www.lacasadisangiorgio.it. Acesso em: 28/08/2013.

15 Giuseppe Felloni explica: "Tra $i$ debiti pubblici amministrati dalla Casa di San Giorgio, le 'compere' costituivano il nucleo più antico ed importante, quello che diede origine alla Casa e ne condizionò gran parte
} 
O endividamento acentuado do Estado, e a dificuldade de instituição de novos impostos para venda do direito de cobrança aos particulares, resultou na formação de um débito consolidado e permanente, originando, já no Século XIII, a primeira comunhão de credores, formada por meio de um consórcio com personalidade jurídica e cujo capital era dividido em frações ideais com valor nominal de 100 libras. $^{16}$

Já a palavra debênture é de origem latina e deriva da palavra debentur, que tem sua raiz no verbo debeo, ou precisamente na voz passiva do verbo debeor (derivações: deberis, deberi, debitus sum), cujo significado é o mesmo do verbo dever, ou em sua derivação "são-me devidos, devem-me" ${ }^{\text {"17 }}$, como apontam os autores ${ }^{18}$ que já discorreram

della gestione per quasi quattro secoli. L'impiego del termine 'compera' nel senso specifico ed in apparenza astruso di debito pubblico affonda le radici nel mercato finanziario genovese del sec. XII, dove sottintendeva due operazioni diverse, seppure simili in apparenza. Con la prima lo Stato, per rendere meno incerto il gettito delle entrate ordinarie e più regolare il suo flusso, vendeva a privati il diritto di riscuotere una determinata imposta per un periodo di tempo prestabilito; il prezzo pattuito era pagato normalmente a rate ed in tale modo il Comune poteva contare su un'entrata regolare, conosciuta in anticipo e coperta da adeguate garanzie, lasciando agli acquirenti i rischi (o i benefici) dell'esazione. La vendita, che avveniva con trattativa privata od in pubblica asta, era chiamata "compera" (del gettito dell'imposta), ma tra gli storici è ormai invalso l'uso di rendere operazioni di tale genere con la parola 'appalto'. Poiché le risorse correnti non erano sufficienti a sostenere le ambizioni espansive dello Stato, ben presto la voragine delle spese, ed in particolare di quelle straordinarie, aprì la strada ad una serie di crescenti disavanzi. Per colmare il deficit si ricorse a prestiti, anche molto onerosi, concessi sovente da mercanti locali o forestieri; ma per lo più i mezzi finanziari vennero raccolti mediante mutui stipulati con gruppi di sovventori e garantiti da redditi demaniali od entrate fiscali. A fronte del capitale ricevuto a prestito, il Comune cedeva al consorzio dei mutuanti il prodotto di una particolare entrata (ossia il suo gettito se era riscossa in economia od il prezzo di aggiudicazione se era stata venduta) e tale prodotto fungeva insieme da pegno per il rimborso, da pagamento degli interessi passivi (che perciò variavano di anno in anno in relazione all'introito della rendita assegnata) ed eventualmente da fondo d'ammortamento. Aggirando il divieto canonico dell'usura, il contratto era assimilato alla costituzione di una rendita (ossia, nella prospettiva dell'acquirente, alla sua 'compera') e, in quanto tale, ritenuto del tutto lecito: giudizio conforme a quello che sarà formulato dal diritto canonico nei secc. XV-XVI con l'approvazione e la regolamentazione del censo consignativo. In questa seconda accezione il termine 'compera', integrato ufficialmente da una locuzione che faceva riferimento al nome dei principali capitalisti, all'importo del prestito o ad altri connotati, designava insieme il mutuo ed il consorzio dei creditori, che era dotato di personalità giuridica, era gestito da uno o più partecipanti e sovente amministrava le entrate comunali ricevute in garanzia." (Disponível em: http://www.lacasadisangiorgio.it/main.php?do=node\&tag=4_4. Acesso em: 28/08/2013).

16 Cf. FELLONI, Giuseppe. Compere di San Giorgio. Disponível em: http://www.lacasadisangiorgio.it/main.php?do=node\&tag=4_4. Acesso em: 28/08/2013.

${ }^{17}$ PEREIRA NETO, Edmur de Andrade Nunes. Aspectos Jurídicos da Emissão de Debêntures Conversíveis em Açães. Dissertação de Mestrado apresentada à Faculdade de Direito da Universidade de São Paulo. 1986, p. 1.

${ }^{18}$ Sobre a origem etimológica da palavra debênture, Waldemar Ferreira (Tratado das Debênturas. $1^{\circ}$ Vol. Rio de Janeiro: Ed. Freitas Bastos, 1944, p. 23), explica que ela "tem suas raízes no verbo latino debeo, es, ui, itum, ere, dever, to owe". Os ingleses lecionam que o termo debenture era aplicado aos recibos - que começavam com as palavras debentur mihi -, e deriva do Latin debentur. Registram que o termo é encontrado em Acts of Parliament ingleses, com o significado de certificado entregue a oficias e soldados para pagamento de soldos atrasados, mas não era usado em relação às companhias: "The term debenture (sometimes spelt debentur or debenter) is found in many old Acts of Parliament, meaning a certificate given to officers or soldiers, which certified that certain arrears were due to them, $(b)$ such arrears were in some cases charged on specified property (such as rebel land in Ireland and land at the disposal of the Commonwealth), (c) in other cases on specified rates and duties (such as the General Fund) (d) But the term is not used in the early Acts of Parliament in relation to Companies, (e) thus the Companies Clauses Act of 1845 speaks of 'bonds and mortgages', and not of 'debentures'. In the same way the instruments, of which a company incorporated under the Companies Act, 1862, is directed to keep a 
sobre o tema. Verifica-se o seu uso desde os tempos da Inglaterra medieval. Anthony Steel ${ }^{19}$ revela que as debentures de Wardrobe foram proibidas no ano de 1304 por Edward $\mathrm{I}^{20}$, da Inglaterra, sinalizando que já àquela época elas eram negociadas com a finalidade lucrativa e apresentavam a característica de instrumento de crédito negociável, muito provavelmente ao portador. Steel ${ }^{21}$ também expõe, referindo-se aos escritos de Mr. J. H. Johnson, que as debentures de Wardrobe foram negociadas, após a proibição do Rei, por dois royal clerks em julho de $1316 .^{22}$

Waldemar Ferreira explica, ao citar Jean Leblond, que os registros das reuniões do Parlamento Inglês, em 1415, revelam o uso da palavra debentur em reclamação de um cidadão londrino a respeito do pagamento de mercadorias fornecidas a Henrique IV, então Rei da Inglaterra. ${ }^{23}$ Herbert W. Jordan recorda que os primeiros certificados de dívida, emitidos pela Coroa Britânica aos soldados por serviços prestados ao governo, recebiam o nome de debentur. $^{24}$

Com o advento das companhias colonizadoras e a necessidade de capitalização para as aventuras mercantes, o termo debenture passou a ser aplicado também para o financiamento do setor privado. Como demonstram os registros, no período de 1671 a 1674 , das reuniões de uma das mais antigas companhias ainda em funcionamento, a Hudson’s Bay

register (section 43), are called 'mortgages' and 'charges', 'debentures' are not specifically mentioned". (SIMONSON, Paul Frederick. A treatise on the law relating to debentures and debentures stock: issued by trading and public companies and by local authorities: with forms and precedents. Londres: E. Wilson, 1899, p. 2. Reprodução do original da Biblioteca da Harvard Law School).

${ }^{19}$ The Negotiation of Wardrobe Debentures in the Fourteenth Century. In: The English Historical Review. Vol. 44. No 175. Oxford University Press, 1929, p. 439-443. Disponível em: http://www.jstor.org/stable/553042. Acesso em 25/01/2013.

${ }^{20}$ Edward I (17 Junho 1239 - 7 Julho 1307) foi Rei da Inglaterra de 1272 a 1307.

${ }^{21}$ Ob. cit., p. 439.

${ }^{22}$ Os precursores, não apenas em emissões por instituições públicas, mas também em emissões por companhias, são os ingleses. Paul Frederick Simonson (Ob. cit., p. vii) registra que, em 1897, as emissões de debentures e debentures stock chegaram a $£ 400,000,000$, representando um quarto do capital social das sociedades inglesas inscritas no Registrar of Joint Stock Companies. (Em 1844, o Parlamento Inglês promulgou o Joint Stock Companies Act para facilitar a constituição e o registro de sociedades mercantis que, àquela época, antes da promulgação dessa lei, somente podiam ser criadas por um ato do governo, de duas formas: (i) Royal Charter emitido pelo Monarca, a exemplo das cartas patentes, que conferiam direitos ou poderes a um indivíduo ou a um grupo de pessoas; ou (ii) Private Act emitido pelo Parlamento, em favor de um indivíduo ou grupo de pessoas, conferindo benefícios, direitos ou a limitação de responsabilidade por certos atos praticados.)

${ }^{23}$ Ob.cit., p. 23. "Em 1415, conta o tratadista, pelo que se referem os Parliamentary Rolls de Henrique IV, certo cidadão de Londres reclamou o pagamento de mercadorias fornecidas a Henrique IV, que os membros da comissão encarregada de examinar as reclamações, 'ne voillent paier la somme suitdit suppliant due, à cause qu'il demonstre pas biles de Debentur desouth le seal du clerk du spicere du dit nadgair Roy, temoignauntz la dette suitdit'. Outros documentos antigos referem-se ao uso do vocábulo há mais de quinhentos anos, até a propósito de soldos de oficiais, soldados ou servidores do rei." (Ob. cit., p. 24).

${ }^{24}$ JORDAN, Herbert W. Debentures and other charges. Legal Treatises, 1800-1926. Reimpressão. Reprodução da Harvard Law School Library. Londres: Jordan \& Sons, 1914, p. 1 e 2. 
Company, a emissão de debêntures era realizada para fomentar a exploração comercial de outros territórios. Os acionistas da Hudson's Bay, por exemplo, subscreveram debêntures que se tornariam, por meio do recebimento de juros, uma das poucas formas de remuneração do capital investido na companhia, tendo em vista que a distribuição de dividendos fora interrompida por um período de 14 anos - a política da companhia era a de evitar a distribuição de dividendos enquanto não houvesse retorno do investimento. ${ }^{25}$

Edmur de Andrade Nunes Pereira Neto aponta, ao citar o jurista italiano Dario Velo, que as debêntures conversíveis em ações foram utilizadas pelas primeiras vezes no século XVII, com amplo uso no início do século XVIII.

Em linha com a origem latina da palavra, o juiz Malms, ao julgar o caso In re Imperial Land Co. of Marseilles, ex pte Colborne and Strawbridge ${ }^{26}$, em 1872, conceituou a debênture como um instrumento revelador de uma situação jurídica em que a parte devedora era obrigada a pagar a dívida contraída junto ao credor. Esse título de dívida, portanto, em razão dos dizeres nele contidos, passou a se chamar debenture. O significado de debênture, assim, está associado ao seu próprio conteúdo revelador de uma dívida, desde os tempos em que se tem notícia de seu uso pela armada britânica.

O uso da palavra debêntures, a partir do Mortgage Debentures Act, de 1865, disseminou-se para outros países "com o significado de 'obrigação' - título de emissão das sociedades anônimas ou em comandita por ações". ${ }^{27}$ Inglez de Souza ensina que o termo obrigação, "representa o crédito resultante da emissão de um empréstimo, ou objetivamente o título negociável que o mutuário entrega ao mutuante como documento e prova do seu direito." 28

O termo obrigação ainda é muito utilizado para se referir à dívida contraída pelas companhias por meio da emissão de títulos em série (Obbligazioni, na Itália, obligation, na França, e obligación, na Espanha). Já o direito alemão denomina o título obrigacionista de Schuldverschreibung. ${ }^{29}$

\footnotetext{
${ }^{25}$ RICH, E.E. Minutes of Hudson Bay Company. Vol. V. Londres: Hudson's Bay Record Society, 1942.

${ }^{26}$ Ob. cit., p. 2.

${ }^{27}$ Edmur de Andrade Nunes Pereira Neto, ob. cit., p. 2.

${ }^{28}$ Apud Waldemar Martins Ferreira, ob. cit., p. 25.

${ }^{29}$ Tavares Borba, ob. cit., p. 3.
} 


\section{EVOLUÇÃO HISTÓRICO-NORMATIVA NO DIREITO BRASILEIRO}

O surgimento das debêntures no Brasil está visceralmente ligado à vinda da família Real portuguesa, em especial ao estabelecimento da indústria e comércio, à história do crédito e à criação das primeiras instituições financeiras brasileiras ${ }^{30}$.

$\mathrm{Na}$ esteira do desenvolvimento econômico e industrial, oriundos da vinda da Corte e dos ingleses $^{31}$ que a acompanharam, um Decreto de 1808 aboliu a proibição de fábricas no Brasil, concedeu isenção a uma série de matérias primas e ainda encerrou o monopólio português sobre exportações. Era o início do período industrial no Brasil, com algumas décadas de atraso (a Revolução Industrial se iniciou na Inglaterra em meados do Século XVIII). ${ }^{32}$

A partir de 1808, portanto, é que o crédito, o giro do dinheiro, o capital privado, passa a ter condições de circular na Colônia portuguesa, tendo em vista a proximidade com o centro de poder - a distância tornava precária a circulação de riquezas em nosso país.

Até a vinda da Coroa portuguesa, conhecia-se apenas o empréstimo público ${ }^{33} \mathrm{e}$ não se tinha notícia de empréstimo em série com captação de recursos privados. Os

\footnotetext{
${ }^{30}$ Carvalho de Mendonça retrata a importância da fundação do Banco do Brasil para o fomento da indústria nacional infante à época: "Oito anos depois de fundado o Banco de França, o Alvará de 12 de outubro daquele ano de 1808 criava no Rio de Janeiro um banco nacional, banco público, que primeiro tomou o nome de Banco do Brasil, tendo por objetivo, além da faculdade de emissão de bilhetes pagáveis ao portador, operações de desconto, comissões, depósitos pecuniários, saques de fundos por contados particulares e do Real Erário, tudo isso dizia o Alvará do Príncipe Regente, afora outros fins, 'para promover a indústria nacional pelo giro e combinação dos capitais isolados"”. (Tratado de Direito Comercial Brasileiro. Vol. IV. Livro II. $4^{\mathrm{a}}$ ed. Rio de Janeiro: Ed. Freitas Bastos, 1946, p. 77).

${ }^{31}$ Um estudioso recorda-nos a influência inglesa no Brasil, quando da abertura dos portos, com a vinda de uma "avalanche de comerciantes ingleses que desembarcou na esteira dos navios da Corte portuguesa que incluía toda espécie de negociante", ressaltando que, em agosto de 1808, "duas centenas de empresas de variado porte possuíam representantes ou agentes no Brasil” (CALDEIRA, Jorge. A Nação Mercantilista. São Paulo: Ed. 34, 1999, p. 326)

32 “A Carta Régia de 28 de janeiro de 1808 abrira os portos do Brasil ao comércio direto estrangeiro.” [...] "Em seguida, o Alvará de $1^{\circ}$ de abril do mesmo ano permitiu o livre estabelecimento de fábricas e manufaturas. Nesse referido ano (1808), como consequência da liberdade de comércio e indústria, o Alvará de 23 de agosto fundara, no Rio de Janeiro, a Real Junta de Comércio, Agricultura, Fábrica e Navegação [...]”. (Ob. cit., p. 76-77)

33 Inglez de Souza (Ob. cit., pp. 15-16) registra que "no Brazil, antes da independência, já se conhecia o empréstimo público, ou cousa parecida. [...] O alvará de 9 de Maio de 1810 mandou considerar antigas todas as
} 
historiadores relatam que os particulares faziam uso da confissão de dívida para formalizar um empréstimo e assegurar que o patrimônio do devedor, ainda que por meio de garantia pessoal, pudesse servir de proteção ao credor. $^{34}$

Com o fim do período colonial, inicia-se a fase de expansão da atividade econômica, com boa parte dos recursos fluindo para o entorno da Corte portuguesa no Rio de Janeiro. ${ }^{35}$ A revogação da política de restrições, até então imposta à Colônia, na esteira da abertura comercial, também favoreceu a transformação econômica. Além disso, "a existência de um instrumento jurídico eficiente de reconhecimento das dívidas e a certeza da cobrança",36 - um título de cobrança reconhecido pelas autoridades -, poderiam tornar a circulação de capitais mais segura e, de certa forma, protegida pelo aparato estatal, facilitando a emissão de títulos, obrigações ou debêntures. ${ }^{37}$

A necessidade de proteção ao crédito levou o Ministro da Justiça, Aureliano Coutinho, em 1834, a defender a elaboração de um Código Comercial. Naquela época o país vivia um período de insegurança, “o comércio do Brasil tomava incremento e não havia

dívidas contraídas até 1797, e marcou prazo aos interessados para apresentarem suas letras ou documentos, sob pena de prescrição. Confirmando a medida, que tinha por fim a liquidação das dívidas da Capitania do Rio de Janeiro, o decreto de 12 de Outubro de 1811 mandou processar no Erário Régio do Rio uma folha da dívida antiga e que segundo apurado se dessem cédulas aos credores, vencendo 6\% ao ano." (Titulos ao Portador no Direito Brazileiro. Rio de Janeiro: Livraria de Francisco Alves, 1898, p. 15/16).

${ }^{34}$ Os historiadores revelaram, em seus estudos sobre o período Colonial, a precariedade da circulação de riquezas em nosso país, como demonstram as linhas a seguir: "Quando se começou a permitir o comércio livre na capital, verificamos que seus comerciantes ignoravam quase por completo o que fosse o crédito; jamais se colocava dinheiro a juros, salvo com o Governo e mesmo então somente em somas que os homens de posse achavam prudente adiantar, e frequentemente com a suspeita de que nunca as haviam de ter de volta. Tinham, como agora, pouca ideia do valor e da influência do capital, como também não possuíam bastante confiança uns nos outros para emprestá-lo sob a forma de cauções ou descontar letras. Havia, na verdade, uma espécie de título a que chamavam um 'crédito', mas que não desempenhava nenhuma das funções de papel-moeda. Pouco mais representava que o reconhecimento de uma dívida e uma declaração de que o credor havia de ser pago mais cedo ou mais tarde com as propriedades e bens do devedor, se acaso falhassem todos os demais meios de solvência." [...] "os comerciantes não tinham confiança para emprestar dinheiro uns aos outros, por um motivo bastante razoável: a suspeita de que não o veriam de volta. Não havia títulos com liquidez, descontáveis no mercado, porque o máximo que se conseguia extrair era uma confissão de dívida - jamais com prazo de liquidação e muito menos com garantia judicial." (Jorge Caldeira, ob. cit., p. 336-337)

${ }^{35}$ PRADO JÚNIOR, Caio. História Econômica do Brasil. $7^{\mathrm{a}}$ edição. São Paulo: Brasiliense, 1962.

${ }^{36}$ Jorge Caldeira, ob. cit., p. 337.

${ }^{37}$ É, porém, com o fim do tráfico de escravos e a necessidade de se buscar novas atividades para o emprego dos recursos, que o Brasil vive um período de grande movimento dos negócios. A repressão brasileira ao tráfico de escravos, iniciada curiosamente em 1850, ano de promulgação do Código Comercial, teve forte influência inglesa a partir da aprovação da Bill Aberdeen (o ato foi aprovado pelo Parlamento inglês, em 08 de agosto de 1845 , influenciando sobremaneira o fim do comércio de escravos), tornando lícita a apreensão de qualquer navio que transportasse escravos da África para o Brasil. 
legislação segura e protetora do crédito. As facilidades e as imoralidades das quebras constituíam meio de vida para muita gente."38

Daí que, em 1850, promulga-se o Código Comercial brasileiro ${ }^{39}$ e se estabelecem as primeiras normas jurídicas codificadas relacionadas à prática comercial. $\mathrm{O}$ referido Código, apesar de tratar das sociedades anônimas ou companhias, e também das sociedades comerciais, não trouxe disposição relativa à emissão de obrigações ou debêntures. ${ }^{40}$

Vivia-se um vácuo legislativo a respeito da emissão de títulos pelas sociedades comerciais, até que, dez anos após a promulgação do Código Comercial, entrou em vigor a Lei $\mathrm{n}^{\mathrm{o}} 1.083$, de 22 de agosto de $1.860^{41}$ - a primeira a usar a expressão "título ao portador" -, proibindo expressamente as companhias de emitir notas, bilhetes, papéis ou títulos ao portador, sem autorização do Poder Legislativo, exceto as instituições financeiras criadas por decreto do Poder Executivo. ${ }^{42}$

A restrição imposta pelo Império, por meio da Lei $\mathrm{n}^{\circ} 1.083$, tinha como pano de fundo a divergência sobre a condução da política econômica e cambial do país, publicamente difundida entre o presidente do Banco do Brasil, Visconde de Itaboraí (defensor do padrão ouro), e o Ministro da Fazenda, Souza Franco (adepto da liberação do crédito e da livre iniciativa), com a participação do Barão de Mauá que, após perder o Banco do Brasil para o governo, decidiu fundar uma sociedade em comandita com a emissão de ações ao portador. $^{43}$

\footnotetext{
${ }^{38}$ Jorge Caldeira, ob. cit, p. 94.

${ }^{39}$ Lei $\mathrm{n}^{\mathrm{o}} 556$, de 25 de junho de 1850.

${ }^{40}$ Waldemar Ferreira (Ob. cit., p. 37) recorda que: "tendo consagrado apenas meia duzia de artigos à sociedade anônima, não aludiu o código do comércio aos títulos, que ela pudesse emitir, ademais das ações representativas de seu capital."

41 “Art. $1^{\circ}[\ldots]$ §10. Nenhum Banco, que não fôr dos actualmente estabelecidos por Decretos do Poder Executivo, Companhia ou Sociedade de qualquer natureza, commerciante ou individuo de qualquer condição, poderá emittir, sem autorisação do poder Legislativo, notas, bilhetes, vales, papel ou titulo algum ao portador, ou com o nome deste em branco, sob pena de multa do quadruplo do seu valor, a qual recahirá integralmente tanto sobre o que emittir como sobre o portador."

${ }^{42}$ CARVALHOSA, Modesto. Comentários à Lei de Sociedades Anônimas. $1^{\circ}$ Vol. $6^{\mathrm{a}}$ ed. São Paulo: Saraiva, 2011, p. 655.

${ }^{43}$ Cf. IUDÍCIBUS, Sergio; RICARDINO FILHO, Álvaro Augusto. A Primeira Lei das Sociedades Anônimas no Brasil. Lei $n^{\circ} 1.083$ - 22 de agosto de 1860. Revista de Contabilidade e Finanças. ${ }^{\circ}{ }^{29}$. Universidade de São Paulo, 2002, pp. 7-25. O artigo é uma verdadeira releitura histórica dos fatos que marcaram a edição da lei 1.083/1860 e demonstra o contexto social que culminou na proibição de emissão de notas e títulos ao portador pelo Império, que temia o chamado "perigo da anarquia monetária".
} 
Diante da crise bancária que eclodiu em 1857 nos Estados Unidos, com efeitos sobre o câmbio no Brasil, o Ministro da Fazenda solicitou ao Banco do Brasil empréstimo para fazer frente às obrigações assumidas pelo governo. Para surpresa do Ministro, o Banco do Brasil se recusou a realizar nova emissão de moeda. A única saída foi buscar recursos junto à sociedade do Barão de Mauá, que acreditava na valorização do Real (moeda da época) sobre a Libra Esterlina, bem como autorizar a emissão de títulos pelos bancos das províncias, como nos recordam Sergio Iudícibus e Álvaro Augusto Ricardino Filho ${ }^{44}$.

Com o fim da crise financeira, já em 1858, preocupado com o funcionamento de novos bancos, a diretoria do Banco do Brasil alertou o Imperador sobre a "anarquia monetária", mediante a restrição ao funcionamento de novas instituições financeiras e, também, à emissão de notas, bilhetes ou títulos ao portador.

Tais restrições, além de outras detalhadas na lei ${ }^{45}$, decorreram de medidas radicais adotadas pelo novo Ministro da Fazenda, Ângelo Muniz da Silva Ferraz, que propôs o texto da Lei $\mathrm{n}^{\circ} 1.083$, com o aparente objetivo de corrigir algumas falhas do Código Comercial em vigor à época.

Foi somente a partir da Lei $\mathrm{n}^{\circ} 3.150$, de 4 de novembro de 1.882 , decretada por Dom Pedro II, que instaurou o regime das disposições normativas, ou da liberdade, na constituição das companhias, que a emissão de obrigações ao portador passou a ser autorizada como meio de contrair empréstimos junto ao público investidor ${ }^{46}$ (“Art. 32. $E^{\prime}$ permittido ás sociedades anonymas contrahir emprestimo de dinheiro por meio de emissão de obrigações ao portador."), introduzindo-se, ainda, no direito brasileiro a expressão obrigações ao portador, herdada do direito continental europeu. $\mathrm{O}$ vocábulo debêntures, por sua vez, foi introduzido em nosso ordenamento pelo artigo $21^{47}$, do Decreto 8.821 , de 30 de dezembro de 1.882, que regulamentou a Lei $n^{\circ} 3.150$, inserindo-o entre parênteses após a

\footnotetext{
${ }^{44}$ Ob. cit., p. 11.

${ }^{45}$ Para exemplificar outras restrições impostas à emissão pelos bancos e sociedades, transcrevemos um artigo da Lei $\mathrm{n}^{\mathrm{o}} 1.083$, de 22 de agosto de 1.860: “Art. $2^{\circ}[\ldots] \S 5^{\circ}$. Em quanto o Governo não declarar constituida huma Companhia ou Sociedade Anonyma, não se poderá emittir, sob qualquer pretexto, titulo algum, cautela, promessa de acções, ou declaração de qualquer natureza, que possa certificar a qualidade de accionista; e ainda depois de constituida, suas acções não serão negociaveis, nem poderão ser cotadas, sem que esteja realisado hum quarto do seu valor."

${ }^{46}$ Sergio Iudícibus e Álvaro Augusto Ricardino Filho, ob. cit., p. 24.

47 “Art. 21. É permittido ás sociedades anonymas contrahir emprestimo por via de obrigações (debentures) ao portador."
} 
palavra obrigações, o que demonstra o entendimento à época de que debêntures e obrigações eram sinônimos.

Já no regime republicano, Waldemar Ferreira ${ }^{48}$ explica que as debêntures ou obrigações foram tratadas pelo Decreto $\mathrm{n}^{\mathrm{o}} 1.641$, de 17 de janeiro de 1.890, acentuando-se, inclusive, "a natureza privilegiada da debêntura, que, antes, podia ser quirografária, por ausência de preceito expresso em contrário", sendo tal ato normativo consolidado no Decreto $\mathrm{n}^{\mathrm{o}} 434$, de 4 de julho de 1.891 , nos artigos $41^{49}$ a 45 , cujos dispositivos foram transcritos do Decreto anterior.

O Decreto $\mathrm{n}^{\mathrm{o}}$ 169-A, de 19 de janeiro de 1.890, que tratou do regime jurídico das hipotecas e ônus reais e da aplicação da lei civil para hipotecas realizadas em favor de credores comerciantes, em seu artigo $5^{\circ}$, parágrafo $1^{\circ}$ e $2^{\circ}$, utiliza a expressão "debêntures ou obrigações ao portador para se referir aos títulos emitidos pelas sociedades anônimas ou comandita por ações, reconhecendo a sujeição do título de dívida àquela norma, especialmente às regras de inscrição das hipotecas convencionais para os instrumentos que possuíssem tal garantia. ${ }^{50}$

Ainda no Século XIX, como ensina Waldemar Ferreira ${ }^{51}$, o Decreto $n^{0} 370$, de 02 de maio de 1.890, ao regulamentar o Decreto 169-A conferiu privilégio especial às debêntures, assegurando sua preferência sobre o imóvel hipotecado quando concorressem com uma hipoteca constituída posteriormente à emissão do título.

A partir da indicação de Leopoldo Bulhões à Câmara dos Deputados e de substitutivo do Senado, relatado por Ruy Barbosa, promulga-se o Decreto ${ }^{\circ}$ 177-A, de 15 de setembro de 1.893, com o objetivo de regular especificamente a emissão de empréstimo em obrigações ao portador, ou debêntures, com novas regras e privilégios, como por exemplo, a preferência a quaisquer outros títulos de dívida que viessem a recair sobre os ativos ou bens da companhia emissora ${ }^{52}$.

\footnotetext{
${ }^{48}$ Ob. cit., p. $39 / 40$.

49 “Art. 41. E' permittido ás sociedades anonymas contrahir emprestimos em dinheiro, dentro ou fóra do paiz, emittindo para esse fim obrigações (debentures) ao portador."

${ }^{50}$ Waldemar Ferreira, ob. cit., p. 24.

${ }^{51}$ Ob. cit., p. 24.

52 Art. $1^{\circ}, \S 1^{\circ}$, do Decreto $\mathrm{n}^{\mathrm{o}} 177-\mathrm{A}$, de 15 de setembro de 1.893 .
} 
Ainda, naquela época, o governo publicou o Decreto $\mathrm{n}^{0} 2.519$, de 22 de maio de 1.897, para regulamentar o artigo $5^{\circ}$, do Decreto 177-A, permitindo à sociedade emissora firmar acordo com os debenturistas ou obrigacionistas sobre "o resgate ou pagamento das mesmas obrigações, estipulando quaisquer cláusulas, contanto que não sejam contrárias a direito" $" 53$.

Interessante destacar que o Decreto 2.519 foi o primeiro ato normativo a reconhecer e admitir a reunião dos portadores de obrigações para discutir as propostas de acordo da companhia, bem como a exigir a designação de um "fiscal" com o encargo de vigiar os direitos e interesses dos obrigacionistas, surgindo a partir daí a figura do agente fiduciário. Seguiram-no o Decreto $\mathrm{n}^{0}$ 22.431, de 06 de fevereiro de 1.933, que revogou o Decreto 2.519, com o propósito específico de regular a comunhão de interesses entre os portadores de "debênturas", porém teve a sua eficácia questionada à época, sendo, posteriormente, substituído pelo Decreto-Lei ${ }^{0} 781$, de 12 de outubro de 1.938, como nos recorda Waldemar Ferreira ${ }^{54}$.

Curioso notar que não consta revogação expressa do Decreto-Lei $n^{0} 781 / 1938$, conforme noticia o Congresso Nacional ${ }^{55}$. Pode-se afirmar, no entanto, que houve revogação parcial no tocante à emissão de debêntures por sociedades anônimas e sociedades em comandita por ações, já que novo regime jurídico sobreveio com a entrada em vigor da Lei $\mathrm{n}^{0}$ 6.404/76. Porém, o referido Decreto-Lei regula também a emissão de obrigações ou debêntures por sociedades autorizadas por lei especial, como é o caso das cooperativas.

Acredita-se que, nesse ponto, o decreto continua em vigor e permite a emissão de debêntures pelas cooperativas, como veremos mais adiante em capítulo próprio sobre o tema.

Em 26 de setembro de 1.940, entra em vigor o Decreto-Lei $\mathrm{n}^{\mathrm{o}} 2.627$, com novo regramento para as sociedades por ações, referindo-se apenas às ações e às partes beneficiárias, como valores mobiliários de sua emissão, sem tratar das debêntures, as quais continuaram reguladas pelo Decreto-Lei n. 781.

53 Art. $1^{\circ}$ do Decreto $\mathrm{n}^{\mathrm{o}} 2.519$, de 22 de maio de 1.897 .

54 Ob. cit., p. 41.

55 Disponível em: http://www2.camara.leg.br/legin/fed/declei/1930-1939/decreto-lei-781-12-outubro-1938350319-norma-pe.html. Acesso em: 27/08/2013. 
Assim, de 1893 a 1976, as debêntures foram reguladas por leis específicas e somente voltariam a ser tratadas no mesmo texto normativo das sociedades por ações a partir da promulgação da Lei n. 6.404, de 15 de dezembro de 1976 (LSA), cujo regramento perdura até os dias de hoje, com algumas modificações.

A LSA trata das debêntures em seu Capítulo V (artigos 52 a 74), com algumas outras disposições esparsas na referida lei, como por exemplo nos artigos 101 (referente à escrituração eletrônica do registro de propriedade das debêntures); 109, IV (direito essencial do acionista à preferência na subscrição de debêntures conversíveis em ações); 122, IV (competência privativa da assembleia geral para autorizar a emissão de debêntures); 163, III (opinião do Conselho Fiscal sobre a emissão de debêntures); 166, III (aumento de capital por meio de conversão de debêntures em ações); 171, $\$ 3^{\circ}$ (direito de preferência dos acionistas à subscrição de debêntures conversíveis); 172 (hipóteses excepcionais de exclusão do direito de preferência à subscrição de debêntures conversíveis em ações); 174, §3 (direito de oposição dos debenturistas à redução de capital, sujeitando-a à aprovação prévia em assembleia especial); 231 (direitos dos debenturistas em operações de incorporação, fusão ou cisão da companhia); 287, II, “d” (prazo prescricional da ação de reparação dos debenturistas em face do agente fiduciário); e 296, $\S 2^{\circ}$ (proteção aos direitos pecuniários dos debenturistas em razão da entrada em vigor da LSA - disposição transitória).

As disposições relativas às debêntures foram modificadas pelos seguintes atos normativos:

(i) Lei 9.457, de 05 de maio de 1997 - ajustou a redação da LSA em função das proibições contidas na Lei $\mathrm{n}^{\circ} 8.021$, de 12 de abril de $1.990^{56}$, que eliminou a possibilidade de emissão de títulos ao portador, em que pese o objetivo primordial da lei foi introduzir maior proteção aos minoritários;

\footnotetext{
${ }^{56}$ Vale registrar que a Lei no 8.021 , de 12 de abril de 1.990, sancionada pelo Presidente Fernado Collor, proibiu o pagamento ou resgate de qualquer título ou aplicação, a partir daquela data, a beneficiário não identificado. A referida lei alterou o texto do art. 20 da LSA, retirando-lhe as palavras "endossáveis" ou "ao portador" e, consequentemente, admitindo apenas a criação de ações nominativas. Não houve alteração expressa da LSA no tocante aos demais valores mobiliários, porém a lei vedou novas emissões de "títulos e a captação de depósitos ou aplicações ao portador ou nominativos-endossáveis” (art. $2^{\circ}$, II).
} 
(ii) Lei $\mathrm{n}^{\circ} 10.303$, de 31 de outubro de 2001 - alterou, entre outras coisas, a exigência de certificado para sua emissão, admitiu livre pactuação de referenciais para correção monetária, permitiu o pagamento do principal e acessório em bens, à escolha do debenturista, autorizou a emissão de debêntures simples pelo conselho de administração da companhia, alterou o local de inscrição da escritura de emissão (do registro de imóveis para o registro do comércio); e

(iii) Medida Provisória 517, de 30 de dezembro de 2010, convertida na Lei 12.431, de 24 de junho de 2011 - eliminou o limite máximo de emissão de debêntures e passou a admitir a autorização do conselho de administração para emissão de debêntures conversíveis em ações, dentro do limite do capital autorizado, dentre outras alterações que serão estudadas em capítulo próprio deste trabalho.

Além dos atos normativos acima citados, há um grande esforço de entidades como a BMF\&Bovespa e a ANBIMA para o aperfeiçoamento de regras que possibilitem o desenvolvimento do chamado "novo mercado de renda fixa" - alusão ao regime diferenciado ou segmento especial de listagem de companhias na própria Bovespa.

Dentre as iniciativas, no âmbito da autoregulação, a publicação do Código ANBIMA de Regulação e Melhores Práticas do Novo Mercado de Renda Fixa, com vigência a partir de 09 de março de 2012, passou a exigir a adoção de certos princípios e normas nas ofertas públicas de debêntures, visando "criar as condições necessárias para o surgimento no Brasil de um mercado de renda fixa capaz de financiar parcelas significativas dos investimentos que serão necessários para o desenvolvimento sustentado da economia” ${ }^{\text {57 }}$.

\footnotetext{
${ }^{57}$ Código ANBIMA de Regulação e Melhores Práticas do Novo Mercado de Renda Fixa, p. 1. Disponível em: http://portal.anbima.com.br/financas-corporativas/regulacao/novo-mercado-renda-fixa/. Acesso em: 29/03/2013.
} 


\section{NOTAS SOBRE DEBÊNTURES NO DIREITO COMPARADO}

O direito comercial, como direito histórico e evolutivo, sempre buscou inspiração no sistema de países desenvolvidos, onde a produção econômica, muito à frente de outros países, exige a necessária evolução do direito para suportar o avanço das práticas comerciais. O mesmo ocorre com as debêntures, cuja evolução ocorreu, e ainda ocorre, em países onde o volume de emissões de títulos de dívida, e os problemas delas decorrentes, justificaram o avanço das normas aplicáveis ao referido instituto.

A evolução dos títulos ou instrumentos financeiros ou de dívida, em que se encaixam as debêntures, desde a sua origem até os dias de hoje, é mais acentuada nos países de origem anglo-saxã, em especial na Inglaterra e nos Estados Unidos, razão pela qual iniciaremos o estudo das debêntures em tais ordenamentos. Por outro lado, é importante analisar o instituto também à luz dos sistemas romano-germânicos, tais como Itália, França e Portugal, visto que os mesmos influenciaram, e de certa forma ainda influenciam, o direito brasileiro.

\subsection{As debêntures no direito anglo-saxão (debentures ou bonds)}

Como mencionado anteriormente, as debêntures foram criadas pelos ingleses para o financiamento público das forças armadas daquele país e, posteriormente, serviram de importante instrumento para a expansão do comércio e das atividades das companhias colonizadoras.

O Student's Law Dictionary ${ }^{58}$ explica que as chamadas Soldiers Debentures foram ordenadas por lei, pela primeira vez, durante o período conhecido como Usurpation of Oliver Cromwell ${ }^{59}$, em 1653, sendo comumente utilizada no Condado de Exchequer como meio de retribuição e pagamento de remuneração aos súditos pelos serviços prestados ao Rei.

\footnotetext{
58 HODGES, James. Londres: E. and R. Nutt, and R. Gosling, 1740. Disponível em: http://find.galegroup.com/ecco. Acesso em 25/01/2013.

${ }_{59}$ Oliver Cromwell tomou o poder e destituiu o Parlamento - Rump Parliament - após a batalha de Worcester.
} 
O entrelaçamento dos interesses público e privado na origem das corporações, em especial das companhias colonizadoras inglesas, poderia explicar a mutação das debêntures de título de dívida emitido pelo poder público para título de dívida de emissão das companhias, em período de importantes transformações na estrutura socioeconômica da época, inclusive com o fim da perseguição ao empréstimo de dinheiro a juros. ${ }^{60}$

Os credores, por sua vez, passaram a ter títulos privados com melhor retorno para o seu investimento, porém com maior risco. As companhias exportadoras e importadoras (trading companies) foram as primeiras a utilizar o instrumento para financiar suas atividades na Inglaterra e nas colônias.

Blackstone, em seus comentários às leis inglesas, no livro dos direitos das coisas, ao analisar a alienação por meio de um instrumento ou título (deed), já mencionava a emissão de uma obrigação ou bond, por meio de um instrumento (deed), em que o proponente (obligor) se comprometia a pagar certa soma de dinheiro a um terceiro em uma determinada data futura. ${ }^{61}$

Paul Simonson explica que de acordo com o Companies Act de 1862, as debêntures poderiam ser emitidas de dois modos: (i) simples debentures; ou (ii) debentures stock. As duas modalidades se distinguiam mais pela forma que por seu conteúdo. Nas debêntures simples, o credor tem direito a certa dívida, separada no balanço da sociedade em nome do debenturista, a qual é paga pela companhia em determinados eventos, ou após o término de certo período definido na escritura de emissão. Já nas debentures stock, o debenturista tem direito a uma parcela, ou um pedaço, da dívida (com ou sem garantia), a qual é usualmente paga ao agente fiduciário nomeado na escritura de emissão em determinadas datas ou após o término do período de duração do título. Neste caso, os debenturistas não

\footnotetext{
${ }^{60}$ A usura foi considerada por muitos anos pecado capital e aqueles que praticavam o empréstimo de dinheiro, mediante a cobrança de juros, como negócio habitual, eram perseguidos e condenados pelos líderes da Igreja, não apenas por ser uma atividade imoral, mas também por ser considerada improdutiva. Por isso, aqueles que exerciam tal atividade recebiam, em contrapartida, apenas o principal emprestado, sem direito a receber qualquer valor adicional a título de juros. A atividade era tão mal vista pela sociedade, sob a influência da Igreja, que os seus praticantes acabavam condenados, execrados, pela opinião pública da época. Nesse sentido: "The practice of charging interest on loans was considered to be unsound in principle; it was condemned by the leaders of the Church not only as being imoral, but on the ground that money itself was unproductive and barren, so that the lender was entitled to no more than the sum advanced, and it was also condemned by public opinion." (JORDAN, Herbert W. Ob. cit., p. 5)

${ }^{61}$ CURRY, William. The Commentaries of Sir William Blackstone, Knt. on the Laws and Constitution of England. Londres: Elibron Classics, 2005, p. 223 (Reprodução original da edição publicada em 1796).
} 
firmam um contrato diretamente com a companhia, mas tem seus direitos assegurados por meio de seu representante (trustee). ${ }^{62}$

$\mathrm{Na}$ Inglaterra, como já afirmado, as debêntures passaram a ser reguladas por norma específica a partir do Mortgage Debentures $A c t^{63}$, de 1865 , sendo largamente utilizadas no início por sociedades cujas atividades estavam relacionadas às ferrovias, canais e mineração.

Posteriormente, as debêntures deixaram de ser reguladas por normas específicas e voltaram a ser reguladas pelos Companies Acts. Atualmente, o Companies Act de 2006 contém uma parte inteiramente dedicada às debêntures e as define por meio da identificação das espécies que podem ser emitidas pelas companhias, incluindo as chamadas debenture stock, bonds e qualquer valor mobiliário emitido que constitua ou não um gravame sobre os ativos da companhia ${ }^{64}$. O termo debênture, portanto, na Inglaterra, seria o gênero que contemplaria as seguintes espécies: (i) debenture stock; (ii) bonds; e (iii) quaisquer outras securities.

Há, portanto, na Inglaterra, a distinção entre debentures bonds, que são as debêntures simples, negociadas por um valor fixo e pré-determinado, e as debentures stocks, que são livremente negociadas em Bolsa, por qualquer valor acordado entre o vendedor e o comprador.

Curioso notar, ainda, que o termo securities é definido pelo Companies Act, na Seção referente ao Takeover Panel, com o significado de shares ou debentures, ou seja, apesar de possuírem regimes jurídicos distintos, as ações e as debêntures pertencem à mesma categoria, a dos valores mobiliários. E mais, as debêntures que possuírem direito de voto nas assembleias da companhia serão tratadas como ações ${ }^{65}$.

\footnotetext{
${ }^{62}$ Paul Simonson, ob. cit., pp. 6-7.

${ }^{63}$ Paul Simonson, ob. cit., p. 2.

${ }^{64}$ Seção 738, inserida na Parte 19, do Companies Act de 2006: “738 Meaning of 'debenture'. In the Companies Acts 'debenture' includes debenture stock, bonds and any other securities of a company, whether or not constituting a charge on the assets of the company."

${ }^{65}$ Companies Act de 2006. Seção 971. "Debentures issued by a company are treated as shares in the company if they carry voting rights".
} 
Já no direito norte-americano, os instrumentos de dívida apresentam três tipos principais: bonds, debentures, e notes. São valores mobiliários que têm a natureza de promissory notes com cláusulas mais elaboradas se comparadas com os empréstimos comuns obtidos junto às instituições financeiras. Normalmente, são utilizados como instrumentos financeiros de longo prazo. ${ }^{66}$

Os bonds são títulos de longo prazo, com vencimento no prazo de 30 anos ou mais a partir da emissão, com garantia da sociedade emissora (collateral). Em razão da garantia apresentada pelo emissor, são conhecidos como secured debts. São emitidos sempre com valor de face (par value) de US\$1,000, sendo que o comprador ou subscritor deve efetuar o pagamento do valor de face na data de emissão do valor mobiliário. O emissor assume a obrigação de devolver o valor de face pago na data de vencimento do título (the bond's maturity date), conforme explica Jeffrey Haas ${ }^{67}$. A emissão de bonds é realizada por meio de um contrato chamado the bond indenture (ou trust deed), como veremos mais adiante.

As debentures, por sua vez, são títulos emitidos também no longo prazo, porém sem garantia da sociedade emissora (unsecured promissory notes). A diferença, portanto, entre as debentures e os bonds, no direito norte-americano, reside na garantia do título ofertada pela sociedade emissora. Além desta relevante diferença, as debêntures são usualmente emitidas com período de duração inferior ao dos bonds (normalmente emitidos com prazo de 30 anos ou mais), em regra com prazo de vencimento de 10 a 20 anos a contar de sua emissão. O título é emitido por meio da debenture indenture, que se assemelha em muito à escritura de emissão dos bonds.

Já as notes são títulos de curto prazo, com período de duração entre 5 a 10 anos. Elas podem ser garantidas pela sociedade emissora, ou não. A emissão das notes é realizada por meio de um contrato chamado note agreement, o qual se assemelha à escritura de emissão dos bonds, com algumas distinções que veremos a seguir. No caso das notes, via de regra, não há a nomeação de um trustee e a relação se dá diretamente entre os note holders e a sociedade emissora.

\footnotetext{
${ }^{66}$ HAAS, Jeffrey J. Corporate Finance. St. Paul: West, 2004, pp. 212-213.

${ }^{67}$ Ob. cit., p. 213.
} 
Como visto acima, a emissão dos títulos de dívida é realizada sempre por meio de dois instrumentos: (i) the indenture; e (ii) the separate bonds. Bond indenture ou debenture indenture são contratos firmados entre o emissor e o indenture trustee (assemelhado ao agente fiduciário brasileiro), sendo o trustee, via de regra, uma instituição financeira que atua como representante dos titulares dos valores mobiliários de dívida (the debt securities), com a finalidade de proteger seus direitos.

A indenture (escritura de emissão) se divide em duas partes: a primeira, direcionada à sociedade emissora, contém todas as obrigações de fazer e de não fazer relacionadas à emissão, assegurando aos debenturistas as garantias necessárias, ou ao menos esperadas, para a subscrição do título; a segunda, por sua vez, estabelece os direitos dos bondholders no caso de descumprimento das obrigações atribuídas à sociedade emissora, bem como regula a relação entre o agente fiduciário (trustee) e os bondholders. As escrituras de emissão dos bonds e das debentures são firmadas pela sociedade emissora e pelo agente fiduciário (trustee). Já o note agreement, por não ter a nomeação de um trustee, é firmado pelo emissor e por todos os titulares das notes.

A redação das indentures, no que tange aos poderes, deveres e obrigações do agente fiduciário, deve seguir os padrões previstos no Trust Indenture Act (TIA) de 1939, alterado pelo Trust Indenture Reform Act (TIRA) de $1990 .^{68}$

O Trust Indenture Act foi promulgado logo após a entrada em vigor dos atos normativos (Securities Act de 1933 e Securities Exchange Act de 1934) que representaram o início do controle estatal federal sobre o mercado de valores mobiliários nos Estados Unidos, em razão da quebra do mercado acionário em 1929. A edição da norma teve por objetivo (i) dar mais transparência aos titulares dos instrumentos de dívida, não apenas no momento da emissão do título, mas durante toda a sua existência até a liquidação; (ii) criar mecanismo de organização dos debenturistas para proteção de seus interesses (a exemplo da comunhão de interesses do direito italiano); e (iii) assegurar que os debenturistas sejam representados por um agente desinteressado, sem conflito de interesses com o emissor, com elevado padrão de conduta, nos moldes das trust institutions. ${ }^{69}$

\footnotetext{
${ }^{68}$ COX, James D.; HAZEN, Thomas Lee. Corporations. $2^{\mathrm{a}}$ ed. New York: Aspen Publishers, 2003, pp. 516-517.

${ }^{69}$ Jeffrey Haas, ob. cit., pp. 218-219.
} 
O TIA define certos requisitos mínimos para uma instituição financeira atuar como agente fiduciário dos debenturistas e restringe a atuação do trustee em situações que possam caracterizar conflito de interesses. Além disso, a referida norma estabelece os deveres e as obrigações do trustee, tais como a emissão periódica de relatórios endereçados aos debenturistas, bem como atribui certos poderes ao agente fiduciário (promover ação em face da emissora, em nome dos debenturistas, em caso de descumprimento das disposições da escritura de emissão ou por falta de pagamento).

Interessante destacar, ainda, que o TIA contém regras ${ }^{70}$ para solucionar situações em que os interesses dos investidores poderiam ser afetados em razão de eventual relação prévia existente entre o emissor e o agente fiduciário. Abordaremos o conflito de interesses e as regras existentes sobre o tema quando tratarmos do agente fiduciário no capítulo referente à tutela dos debenturistas.

A doutrina norte-americana também classifica a relação entre o agente fiduciário e os debenturistas de diversas formas: (i) fiduciary (relação de fidúcia); (ii) principal-agent law (teoria fundada nas regras gerais aplicáveis às relações entre mandante e mandatário); e (iii) baseada em direito contratual, conforme definido na escritura de emissão do título. ${ }^{71}$

Destaca-se, ainda, que os bonds e as debentures são emitidos com base na capacidade atual ou futura de geração de caixa da sociedade emissora, muito mais do que contra seus ativos, segundo a doutrina norte-americana. O financiamento da companhia por meio de dívida é mais flexível que a capitalização com base em emissão de novas ações, pois não depende de aprovação dos sócios ou acionistas da sociedade, exceto com relação aos títulos conversíveis em ações.

\footnotetext{
${ }^{70}$ De acordo com Jeffrey Haas (Ob. cit., pp. 222-223), a Seção 310(b) do TIA estabelece nove situações em que o agente fiduciário será considerado em situação de conflito de interesses que poderá prejudicar os titulares de debentures, bonds ou notes. Cita como exemplo a hipótese em que o agente fiduciário detém um percentual de participação na sociedade emissora. Em caso de se verificar uma das hipóteses previstas no TIA, o agente fiduciário deverá se desvencilhar da situação de conflito em noventa dias ou renunciar à posição. Se não o fizer, deverá notificar os debt holders, os quais poderão destituí-lo e eleger novo trustee. Além disso, as regras de conflito de interesses foram modificadas pelo Trust Indenture Reform Act que, atualmente, proíbe o agente fiduciário de ser credor ou acionista da sociedade emissora, bem como proíbe que a relação com a sociedade emissora exista ao mesmo tempo em que houve o descumprimento da escritura ou falta de pagamento - situação de default. $\mathrm{O}$ agente fiduciário não precisará renunciar caso demonstre que isto trará prejuízos aos detentores do título e que o defatult poderá ser sanado em tempo razoável.

${ }^{71}$ Cox e Hazen, ob. cit., p. 518.
} 


\subsection{As debêntures no direito italiano (obbligazioni)}

A evolução histórica das sociedades medievais, em especial as italianas, apresentam os primeiros traços dos títulos de dívida criados pelos comerciantes ou mercadores para estruturar o financiamento, em série, visando captar dinheiro para os seus negócios, de modo a incentivar os financiadores, escapando da proibição da usura ${ }^{72}$ (um cânone essencial do sistema obrigacional longamente vigente na experiência jurídica pregressa).

Admitia-se o empréstimo por meio de mútuo, porém sem a cobrança de juros, retornando apenas o principal ao financiador, o que muitas vezes não gerava um incentivo para colocação do capital a risco. O mútuo, assim, era visto como um empréstimo gratuito e que obrigava o mutuário a retornar o valor principal ao mutuante, sem o pagamento de juros ou qualquer outro acréscimo.

Para fugir da ilicitude, era necessário qualificar o empréstimo oneroso com nomen iuris diverso do mútuo. Assim, para financiar a atividade mercantil da época, nas grandes praças da Itália do Século XI, surge uma figura contratual - que recebe diversas denominações, tais como: commenda, accomandita, accomandiglia, collegantia, societas maris ou hentrica -, em que o comerciante (tractator) recebia de um capitalista uma "subvenção" ou empréstimo com a obrigação de restitui-lo por meio da partilha do resultado da empresa (geralmente, três quartos para quem conferiu o capital e um quarto para o tractator), sem caracterizar um ilícito. ${ }^{73} \mathrm{O}$ tractator, por sua vez, não era obrigado a restituir o principal caso o negócio viesse a falir sem a sua culpa, diferentemente do mútuo em que persistia a necessidade de pagamento da obrigação principal.

\footnotetext{
${ }^{72}$ A usura surgiu a partir de interpretação de passagens do Antigo Testamento (P. ex.: Êxodo XXII, 25: "Se fizerem empréstimo a alguém do meu povo, a algum necessitado que viva entre vocês, não cobrem juros dele; não emprestem visando a lucro."; Deuteronômio XXIII, 19: "Não cobrem juros, por dinheiro, alimento, ou qualquer outra coisa que possa render juros.). Santarelli explica que se tratava de uma situação totalmente imoral aproveitar-se do desespero daquele que necessita de dinheiro para financiar a sua atividade, com vantagem econômica para o financiador (Mercanti e Società Tra Mercanti. $3^{a}$. ed. Turim: Giappichelli, 1998, pp. 153-154).

${ }^{73}$ Santarelli, ob. cit., p. 173.
} 
Nesse ponto, é interessante notar o entrelaçamento entre a posição de credor e, ao mesmo tempo, a de sócio, daquele que realizava o empréstimo. Santarelli, inclusive, chega a afirmar que houve uma transposição causal do financiamento da empresa, por meio da comenda, em uma sociedade, derrubando a proibição da usura, tendo em vista que o contexto sistemático da época não previa a tipicidade contratual. Afirma, ainda, que nesse contexto a sociedade constituída para exercer a função própria do mútuo poderia ser chamada de negócio indireto. $^{74}$

Com isso, o sujeito que passou a financiar a empresa recebia um título que lhe atribuía o direito de participar dos resultados daquele negócio, porém sem direito de ingerência na administração da sociedade e, consequentemente, sem responder pelas obrigações contraídas pelo comerciante junto a terceiros, limitando seu próprio risco.

Nota-se que as características desse negócio indireto ${ }^{75}$, que ocultava um mútuo oneroso, são vistas atualmente nas obrigações do direito italiano, especialmente no que tange à não participação do obrigacionista na administração da sociedade, com algumas exceções, e à não responsabilização por obrigações contraídas junto a terceiros.

Já a disciplina jurídica das obrigações no direito comercial italiano remonta ao início de sua codificação ${ }^{76}$. Os primeiros códigos foram os marítimos, tendo em vista a importância daquele comércio à época. O Livro IV do Código Marítimo de Ferdinando já tratava das obrigações marítimas, que nos parece ser a fonte dos títulos obrigacionais emitidos pelas sociedades italianas, com grande influência do direito romano em sua construção.

O Código Marítimo de Ferdinando já apresentava o conceito de obrigação, com base nas Institutas de Justiniano (Livro 3, Título 13), da seguinte forma: “L’Obbligazione è

\footnotetext{
${ }^{74}$ Santarelli, ob. cit., p. 187.

${ }^{75}$ A esse respeito, Tullio Ascarelli elaborou com maestria artigo dedicado ao estudo do negócio indireto. (In: Problemas das Sociedades Anônimas e Direito Comparado. $1^{\mathrm{a}}$ Reimp. São Paulo: Ed. Quorum, 2008, pp. 152250).

${ }_{76}$ As origens da codificação do direito comercial na Itália remontam à época pré-napoleônica, do período veneziano, com a vigência do Código Marítimo de 1781 do Reino de Nápoles e do Código Mercantil da República de Veneza. Na Itália pós-napoleônica, ainda dividida em reinos autônomos, Carlo Alberto di Savoia (il Magnanimo) promulgou em 1842 um novo Código Comercial para o Reino da Sardenha que, apesar de se basear no Código de Napoleão, adequou o ordenamento da época ao progresso econômico e industrial europeu.
} 
um vincolo di legge, per cui siamo necessariamente costretti di pagar qualche cosa secondo le nostre leggi."77

Curioso notar, ainda, que o Código de Ferdinando estabelecia que a obrigação marítima, surgida a partir de consenso entre as partes, poderia ser a compra e venda, a locação, a sociedade e o mandato. ${ }^{78}$ Mais uma vez, a obrigação aparece como fonte de criação da sociedade, assim como o era para escapar da ilicitude da usura, caracterizando um negócio jurídico consensual.

Se a constituição da sociedade e, por consequência, a criação dos títulos de participação societária eram vistos como fonte criadora de obrigações, de natureza consensual, a doutrina parece que seguiu a mesma linha de raciocínio e adotou o termo “obrigações” para a emissão de títulos de dívida. Neste caso, confundiu-se a fonte criadora e o produto da criação.

O primeiro código, após a unificação dos reinos italianos, que tratou das obrigações na forma de títulos emitidos pelas sociedades, de que se tem notícia, é o Codice di Commercio del Regno D'Italia, promulgado em 25 de junho de 1865, em Florença (Firenze), pelo Rei Vittorio Emanuele ${ }^{79}$. Tal Código tratou das disposições comuns às sociedades anônimas e às sociedades em comandita por ações, em seu artigo 135, estabelecendo que " $a$ sociedade não pode emitir obrigações ao portador, sem que o capital social tenha sido integralizado. O montante da obrigação e do título não podem exceder o valor do capital social integralizado" ${ }^{\prime 80}$.

Alguns anos após, há a promulgação de um novo código: o Codice di Commercio del 1882. Transporta-se grande parte das regras do Código Oitocentista de 1865 para o novo diploma comercial, evidenciando a qualidade do modelo adotado na primeira

\footnotetext{
${ }^{77}$ MOSCHETTI. Cesare Maria. Il Codice Marittimo del 1781 di Michele de Jorio per Il Regno di Napoli. Vol. II. Nápoles: Giannini Editore, 1979, p. 839.

${ }^{78}$ Cesare Moschetti, ob. cit., p. 887.

${ }^{79}$ Codice di Commercio del Regno D'Italia. Florença: Stamperia Reale, 1866. O Livro I, Título VII, tratou do regramento da sociedade e associação comercial e a Seção VII, do Título VII, que regulou as sociedades anônimas e as em comandita por ações, tratou da emissão de obrigações pelas sociedades.

80 "La società non può emettere obbligazioni od altri titoli al portatore, sinchè non sia versato l'intero capital sociale. Il montare delle obbligazioni e dei titoli non potrà mai eccedere quello dei capitale versato." (Codice di Commercio del Regno D'Italia. Florença: Stamperia Reale, 1866)
} 
codificação comercial italiana, o que pode ser observado nos debates travados por juristas do mais alto renome à época, como nos mostra Antonio Padoa Schioppa ${ }^{81}$.

Após a promulgação do Código de 1882, surgiram novas tentativas de reforma do diploma comercial. O Congresso da Sociedade Econômica, realizado em Turim, em 1893, aprovou, após intensos debates, com a participação ativa de Cesare Vivante, dez propostas de reforma em matéria societária, sendo que uma delas estabelecia a possibilidade de constituição de um consórcio pelos obrigacionistas, com representante próprio. Certamente, tal proposta foi a primeira tentativa de se positivar a comunhão dos debenturistas. ${ }^{82}$

Em 1895 e em 1905, foram criadas Comissões Ministeriais para revisão do Código Comercial Italiano, com a participação de Cesare Vivante e Marco Besso. Os trabalhos das duas comissões resultaram em um projeto de reforma que, pela primeira vez, permitia a criação de uma assembleia de obrigacionistas. ${ }^{83}$ Por outro lado, as inovações contidas no projeto liderado por Vivante levaram a Confederação Geral da Indústria italiana a apresentar um contraprojeto denominado Progetto D'Amelio, que rejeitava a ideia da tal assembleia.

Apesar da qualidade dos projetos para um novo Código Comercial, as modificações somente ocorreram por meio de leis especiais durante o período do fascismo. Em 1927, por exemplo, a R.D.L. $n^{\circ}$ 628, de 21 de abril, passou a admitir a emissão de obrigações, em casos excepcionais, acima do limite máximo (valor do capital social integralizado) estabelecido no Código Comercial, tendo em vista o interesse da economia nacional e mediante prévia autorização do Ministro competente. ${ }^{84}$

O Código de 1882 permaneceu em vigor até a reforma que resultou na unificação do direito privado em 1942, com a promulgação do Código Civil Italiano (“CCI'), o qual passou a regular tanto a matéria civil como a de natureza comercial, tratando da emissão de obrigações pelas sociedades anônimas em seu Livro Quinto (Del Lavoro), Capítulo V (Sociedades Anônimas), Seção VII (Das Obrigações).

\footnotetext{
81 Saggi di Storia Del Diritto Commerciale. Milão: LED, 2009, pp. 205-207.

${ }^{82}$ Schioppa, ob. cit., p. 228.

${ }^{83}$ Schioppa, ob. cit., p. 233.

${ }^{84}$ Schioppa, ob. cit., p. 245.
} 
A reforma do CCI em 2003 promoveu a autonomia estatutária como forma de incentivar o investimento nas sociedades empresárias, reformulando toda a disciplina do chamado "título de dívida" não participativo e apresentando um sistema categorizado da seguinte forma: a) obrigações de conteúdo essencialmente típico: ordinária, subordinada, variável e conversível em ação; b) título de dívida (instrumento financeiro) atípico de conteúdo essencialmente típico; e c) título de dívida absolutamente atípico. ${ }^{85}$

Outra novidade da reforma é a possibilidade de emissão de título de dívida pelas sociedades de responsabilidade limitada, como veremos em capítulo próprio, bem como por sociedades cooperativas (art. 2526, co. 1., do CCI). A reforma ainda inovou em matéria de competência para emissão de obrigações não conversíveis, conferindo poder decisório à administração da sociedade, salvo disposição diversa no estatuto ou em lei.

Com relação ao limite de emissão, ampliou-se o critério para duas vezes o valor do capital social, da reserva legal e da reserva disponível no resultado do último balanço, admitindo-se ainda que o capital tenha sido apenas subscrito, não se exigindo a sua integralização como na regra anteriormente vigente no CCI. A regra até então em vigor, antes da reforma de 2003, era aquela herdada do Código de Comércio de 1865, que previa o limite de emissão de uma vez o capital social subscrito e integralizado.

O limite, todavia, não se aplica às obrigações destinadas à circulação no mercado de capitais, tendo em vista a existência de normas que asseguram adequada vigilância do mercado e fácil acesso à informação pelos subscritores, além de serem avaliadas por agências de rating com base no patrimônio líquido e no nível de endividamento da sociedade emissora.

Como pudemos observar, a história das obrigações (debêntures) no direito italiano está ligada à evolução das normas de direito comercial e, em especial, do tratamento jurídico conferido às sociedades anônimas, evidentemente o instituto jurídico e econômico mais relevante do último Século.

${ }^{85}$ GAMBINO, Agostino e SANTOSUOSSO, Daniele U. Fondamenti di Diritto Commerciale (a cura di Agostino Gambino). Società di Capitali. Vol. II. $3^{\mathrm{a}}$ ed. Turim: G. Giappichelli, 2010, pp. 186-187. 


\subsection{As debêntures no direito francês (obligations)}

O direito francês tem uma abordagem diferenciada para as debêntures, tendo em vista a existência de uma disciplina geral dos valores mobiliários. As obligations são consideradas títulos de dívida negociáveis e espécie do gênero instruments financiers, que representam valeurs mobilières ${ }^{86}$, conforme art. L. 211-1 do Code des sociétés francês. Com isso, a teoria geral dos valores mobiliários cuida de grande parte da análise do regime jurídico das debêntures.

Para a doutrina francesa, os títulos de dívida pertencem à categoria dos títulos financeiros que, por sua vez, são espécie do gênero instrumentos financeiros. As obligations como se denominam as debêntures no direito francês -, caracterizam-se como um empréstimo realizado pelos obrigacionistas à sociedade que, em contrapartida, têm o direito de reembolso do capital emprestado, nos termos fixados na escritura de emissão, sendo o referido valor mobiliário regulado por um Decreto-lei de 30 de outubro de $1935 .^{87}$

A natureza jurídica das obrigações, em razão de suas regras comuns, é a de títulos negociáveis fungíveis, provenientes de uma mesma categoria e de uma mesma emissão, que se transmitem por simples lançamento de conta a conta em um sistema escritural - desmaterialização do título -, conferindo aos seus titulares os mesmos "direitos mobiliários". 88

Os direitos mobiliários incorporam-se no título e passam a ser conferidos ao seu titular, não como direito individual ou pessoal em face da sociedade, mas categorizados como direito coletivo que recai sobre os bens sociais. Por consequência, o seu exercício depende da vontade coletiva emanada do órgão que reúne e vincula os titulares das obrigações ou debêntures.

\footnotetext{
${ }^{86}$ Cf. (i) RIPERT, G.; ROBLOT, R., Traité de Droit Commercial. Les Sociétés Commerciales. $19^{\mathrm{a}}$ ed. Tomo 1. Vol. 2., sob a direção de GERMAIN, Michel e colaboração de MAGNIER; Véronique. Paris: L.G.D.J., 2009, p. 559; e (ii) MERLE, Philippe. Droit Commercial. Sociétés Commerciales. 11ª ed. Paris: Dalloz, 2007, p. 300.

${ }^{87}$ Merle, ob. cit., pp. 295-296.

${ }^{88}$ Merle, ob. cit., p. 300.
} 
As obrigações são, portanto, títulos negociáveis que evidenciam uma dívida de longo prazo da sociedade emissora, conferindo aos titulares que os subscreveram direitos mobiliários inerentes ao título emitido, possuindo os seguintes elementos em sua definição: os títulos, a negociabilidade, a emissão, a subscrição e os direitos conferidos aos titulares dos valores mobiliários. ${ }^{89}$

A doutrina francesa ainda destaca as vantagens do título obrigacional em relação ao empréstimo bancário. Merle afirma que a emissão de obrigações preserva a independência da sociedade em razão da multiplicidade de credores, mesmo agrupados em uma comunhão de interesses, diferenciando-se daquela dívida contraída junto a um único credor, profissional, que é a instituição financeira. ${ }^{90}$

As sociedades francesas passaram a recorrer à emissão de obrigações a partir da metade do Século XIX. A Crédit Foncier de France, sociedade de crédito francesa, foi uma das primeiras a lançar obrigações de dívida naquele país. A liberdade contratual permitia que as emissões de obrigações fossem realizadas com base na vontade do emissor, sem qualquer regramento no tocante à forma ou aos direitos inerentes aos subscritores do título. As obrigações podiam ser emitidas por meio de títulos ao portador ou nominativos. Para a doutrina, a principal característica do título obrigacional era a reunião de seus titulares em um grupamento, qualificado como uma sociedade civil, vinculando juridicamente os titulares em razão da unicidade do título. ${ }^{91}$

Após as primeiras emissões em França, o legislativo francês editou a lei de 30 de janeiro de 1907, visando a proteção dos investidores. Posteriormente, um Decreto-lei de 30 de outubro de 1935, relativo à proteção dos obrigacionistas, estabeleceu também um texto geral sobre as obrigações.

Atualmente, o regime jurídico de emissão das obligations pelas sociedades por ações está previsto no Código de Comércio Francês (art. L. 228-38 ${ }^{92}$ ), que nos remete às

\footnotetext{
${ }^{89}$ Cf. LE CANNU, Paul. Droit des sociétés. $2^{\mathrm{a}}$ ed. Paris: Montchrestien, pp. 653-654.

${ }^{90}$ Ob. cit., p. 383.

${ }^{91}$ Ripert e Roblot, ob. cit., p. 566.

92 "Comme il est dit à l'article L. 213-5 du code monétaire et financier: 'Art. L213-5 - Les obligations sont des titres négociables qui, dans une même émission, confèrent les mêmes droits de créance pour une même valeur nominale'."
} 
disposições do Código Monetário e Financeiro (por exemplo, art. L. 213-5 e seguintes) daquele país, dentre outras normas não codificadas. ${ }^{93}$

Além disso, o ordenamento jurídico francês apresenta mais dois regimes jurídicos de emissão de obrigações, conforme o tipo societário adotado pelo emissor, a saber: (i) regime de emissão pelos grupamentos de interesse econômico (Código Monetário e Financeiro, art. L. 213-7); e (ii) regime de emissão das associações (Código Monetário e Financeiro, art. L. 213-8, L. 231-2, L. 213-18-1, R. 213-21 et s., R. 231-2 et D. 213-17 et s.).

Os dois regimes acima apontados, distintos daquele das sociedades por ações, demonstram a possibilidade de emissão de debêntures por outros tipos societários. Trataremos, mais adiante, em capítulo específico, do regime instituído pela Ordonnance $\mathrm{n}^{\circ}$ 2004-274 de 25 de março de 2004, que passou a admitir a emissão de obrigações pela SARL (Société à responsabilité limitée $)^{94}$, outra inovação na legislação francesa que, talvez, possa auxiliar a reduzir o preconceito em relação à emissão de valores mobiliários por sociedades empresárias limitadas em nosso sistema atual.

\subsection{As debêntures no direito português (obrigações)}

Tem-se notícia de uma das primeiras emissões de obrigações em Portugal, no ano de 1.757, pela Fábrica das Sedas. Os títulos públicos de dívida, especialmente a partir do Decreto de 29 de outubro de 1.796 - que autorizou o empréstimo mediante a aceitação de dinheiro contra a entrega de apólices, com valor nominal de cem mil reis cada, no valor total

\footnotetext{
${ }^{93}$ Cf. informações disponíveis em: http://www.legifrance.gouv.fr. Acesso em: 20/04/2013.

94 "Article 12. L'article L. 223-11 du code de commerce est remplacé par les dispositions suivantes: «Art. L. 223-11. - Une société à responsabilité limitée, tenue en vertu de l'article L. 223-35 de désigner un commissaire aux comptes et dont les comptes des trois derniers exercices de douze mois ont été régulièrement approuvés par les associés, peut, sans faire appel public à l'épargne, émettre des obligations nominatives. "L'émission d'obligations est décidée par l'assemblée générale des associés conformément aux dispositions applicables aux assemblées générales d'actionnaires. Ces titres sont soumis aux dispositions applicables aux obligations émises par les sociétés par actions, à l'exclusion de celles prévues par les articles L. 228-39 à L. 228-43 et L. 228-51. "Lors de chaque émission d'obligations par une société remplissant les conditions de l'alinéa ler, la société doit mettre à la disposition des souscripteurs une notice relative aux conditions de l'émission et un document d'information selon les modalités fixées par décret en Conseil d'Etat. "A peine de nullité de la garantie, il est interdit à une société à responsabilité limitée de garantir une émission de valeurs mobilières, sauf si l'émission est faite par une société de développement régional ou s'il s'agit d'une émission d'obligations bénéficiant de la garantie subsidiaire de l'Etat.»"
} 
de 10 milhões de cruzados, a juro anual de 5\% -, também exerceram papel fundamental para que as obrigações viessem a lume naquele país. ${ }^{95}$

Menezes Cordeiro ensina que o regime jurídico das obrigações no direito português veio a ser disciplinado a partir da Lei sobre as Sociedades Anónimas, de 22 de junho de 1.867, em seção específica (VII). Posteriormente, com a edição do Código Comercial de 1.888, chamado Código Veiga Beirão, a emissão de obrigações passou a ser disciplinada na seção reservada às sociedades anônimas. Com a crise financeira de 1.891, conta-nos Menezes Cordeiro que o Estado passou a restringir a emissão de obrigações e, por meio de leis e decretos que se sucederam, condicionou a sua criação à prévia aprovação do Governo, conforme registrado no Decreto de 12 de julho de 1.894 - aplicável aos bancos -, na Lei de 3 de abril de 1.896 e no Decreto de 27 de agosto de 1.896 - de aplicação geral a todas as sociedades anônimas, independentemente da atividade exercida. Este último Decreto, ainda, pela primeira vez no ordenamento jurídico português, previu a figura da assembleia geral dos obrigacionistas. ${ }^{96}$

Engrácia Antunes ${ }^{97}$, por sua vez, em trabalho apresentado no âmbito do Concurso para Professor Associado da Universidade Católica Portuguesa, afirma que as obrigações emitidas por sociedades foram tratadas a partir da Lei de 3 de Abril de 1.896, sendo posteriormente alterada por sucessivos atos normativos ${ }^{98}$.

Atualmente, a matéria é regulada pelo Código das Sociedades Comerciais de 1.986, com destaque para a "progressiva mobiliarização das obrigações", que são vistas "como um instrumento financeiro, base de valores mobiliários e que apenas por tradição está ligado às sociedades anônimas" 99 , sinalizando, assim, que as obrigações são independentes e possuem regime jurídico próprio, não se vinculado necessariamente à disciplina das sociedades anônimas, até porque passíveis de serem emitidas por outros tipos societários.

\footnotetext{
${ }_{95}$ CORDEIRO, António Menezes. Manual de Direito das Sociedades. $2^{\text {a }}$ ed. Coimbra: Almedina, 2007, p. 715.

${ }^{96}$ Menezes Cordeiro, ob. cit., pp. 715-718.

97 ANTUNES, José A. Engrácia. Direito das Sociedades Comerciais. Perspectivas do seu ensino. Coimbra: Almedina, 2000, p. 47.

${ }^{98}$ Os atos normativos foram os seguintes: Regulamento de 27 de agosto de 1896, Decreto $\mathrm{n}^{\mathrm{o}} 34961$, de 2 de outubro de 1.945, Decreto-Lei n ${ }^{\circ} 353-\mathrm{M} \mathrm{e} \mathrm{n}^{\mathrm{o}} 353-\mathrm{P}$, de 29 de agosto de 1.977.

${ }^{99}$ Menezes Cordeiro, ob. cit., p. 719.
} 
Aquele regime jurídico também considera as obrigações como valores mobiliários, conforme definição contida no artigo 348. $/ 1$ e 1. \%/1, "b", do Código de Valores Mobiliários Português.

Assim, observa Paulo Olavo Cunha, a matéria é regulada tanto pelo Código das Sociedades Comerciais, "no qual se determinam os requisitos a que os empréstimos obrigacionistas devem obedecer e as modalidades que podem revestir", como pelo Código dos Valores Mobiliários, "onde se estabelece o regime dos valores mobiliários, de que constituem uma das principais espécies". 100

As modalidades das obrigações podem adotar diversas formas, inexistindo nessa seara o princípio da tipicidade que obrigaria ao emissor adotar uma forma preestabelecida para a colocação, pública ou privada, do título. A doutrina portuguesa entende que as modalidades dispostas no artigo $360 .^{\circ}$ do Código das Sociedades Comerciais são meramente exemplificativas, baseadas em direitos conferidos aos obrigacionistas, sem limitar o campo de criação de modelos diversos daqueles dispostos no regime codificado.

Menezes Cordeiro resume as cinco modalidades de obrigações no direito português da seguinte forma:

“a) Além de conferirem aos seus titulares o direito a um juro fixo, os habilitem a um juro suplementar ou a um prémio de reembolso, quer fixo quer dependente dos lucros realizados pela sociedade;

b) Apresentem juro e plano de reembolso, dependentes e variáveis em função dos lucros;

c) Sejam convertíveis em acções;

d) Confiram o direito a subscrever uma ou várias acções;

e) Apresentem prémios de emissão."101 (conforme o original)

Recorda-nos, ainda, o notável jurista português, que as obrigações conversíveis em ações foram introduzidas naquele país pelo Decreto-Lei ${ }^{0} 397$, de 22 de setembro de 1.971 - neste ponto, o direito brasileiro foi inovador e introduziu a modalidade conversível em ações em 1.965, por meio da Lei $n^{0} 4.728$ daquele ano, como nos recorda Edmur de Andrade Nunes Pereira Neto, em sua dissertação sobre o tema. ${ }^{102}$ Curioso registrar, ainda, que

\footnotetext{
${ }^{100}$ Direito das Sociedades Comerciais. $5^{\mathrm{a}}$ ed. Coimbra: Almedina, 2012, p. 825.

${ }^{101}$ Ob. cit., p. 727.

102 Ob. cit., p. 44.
} 
mesmo em Portugal, os estudos monográficos sobre o assunto surgiram nos idos de 1.999, conforme bem observa Menezes Cordeiro. ${ }^{103}$

${ }^{103}$ Menezes Cordeiro (Ob. cit., p. 720 e nota de rodapé 1808) destaca as obras de Fátima Gomes (Obrigações conversíveis em acções, de 1999), António Silva Dias (Financiamento de sociedades por emissão de obrigações, de 2002) e de Nuno Barbosa (Competência das assembleias de obrigacionistas, também de 2002). 


\section{CONCEITO E NATUREZA JURÍDICA}

Para se chegar ao conceito atualizado de debêntures, temos que analisar previamente a sua natureza jurídica, ainda que evolutiva e híbrida pelo advento de novas regras jurídicas. Todas as definições construídas pela doutrina de outrora são influenciadas pela evolução dos estudos acerca da natureza jurídica do instituto em análise. A definição clássica de debêntures, que toma como base a teoria do mútuo ${ }^{104}$, considera o título um documento que comprova a existência de um empréstimo, mais especificamente um mútuo firmado entre a companhia e o debenturista, partindo da relação de débito e crédito ${ }^{105}$ originada com a emissão da obrigação. ${ }^{106}$

Inglez de Souza, no Século XIX, já explicava que a debênture "representa o crédito resultante da emissão de um empréstimo, ou objetivamente o título negociável que o mutuário entrega ao mutuante como documento e prova do seu direito" ${ }^{107}$, revestindo, portanto, um contrato de mútuo. Já a teoria alemã, à época da obra escrita por Inglez de Souza, enxergava um contrato de venda na subscrição das debêntures, por entender que a emissão seria uma manifestação unilateral de vontade. ${ }^{108}$

\footnotetext{
${ }^{104}$ Como bem observado por Edmur de Andrade Nunes Pereira Neto (Ob. cit., p. 33), "a teoria do mútuo ainda prevalece na doutrina brasileira. A quase totalidade de nossos juristas enxerga na emissão de debêntures uma modalidade especial do mútuo, caracterizada pela divisão da quantia mutuada em frações, atribuídas a diversos titulares que se tornam credores ligados entre si pelo vínculo comum de uma só operação que dá nascimento às debêntures." E acrescenta ainda que a referida teoria tem larga aceitação na doutrina estrangeira, em especial na doutrina italiana e francesa.

105 "O crédito é, pois, economicamente, a negociação de uma obrigação futura; é a utilização dessa obrigação futura para a realização de negócios atuais. É, em suma, como diz Werner Sombart, o poder de compra conferido a quem não tem o dinheiro necessário para realizá-la. Ou, como já dizia Stuart Mill, é a permissão de usar o capital de outrem.” (BORGES, João Eunápio. Títulos de Crédito. $2^{\mathrm{a}}$ ed. Rio de Janeiro: Forense, 1971, p. 7.)

${ }^{106}$ Galgano diferencia o capitale di debito - aquele em que há o aporte de recursos por meio de um instrumento de dívida - do capitale di rischio - em que o financiamento da empresa ocorre por meio da emissão de ações. $\mathrm{O}$ obrigacionista não corre o risco da atividade empresarial, por não ser sócio, e tem direito ao reembolso de seu título com base no valor nominal nele inscrito; é um título de renda fixa, resgatável e com prazo determinado. $\mathrm{O}$ acionista, de outro modo, tem o seu investimento atrelado ao risco do negócio, posto que o valor de sua ação poderá oscilar e o rendimento do capital dependerá do resultado da companhia, sendo, por conseguinte, um título de renda variável, com limitações ao resgate e, na maioria dos casos, por prazo indeterminado.

${ }^{107}$ Ob. cit., p. 267.

${ }^{108}$ Inglez de Souza, ob. cit., p. 267.
} 
Francesco Giancola, ao comentar o art. 2.410 do Código Civil Italiano, afirma que a emissão de debêntures é uma forma de financiamento da sociedade, mediante a captação de recursos junto ao mercado, "a titolo di mutuo". ${ }^{109}$ (grifo do autor)

Para a teoria do mútuo, os debenturistas são credores da sociedade e o título incorpora apenas um direito de crédito, diferentemente da ação, que confere a qualidade de sócio, com outros direitos inerentes ao status socii. O obrigacionista realiza um empréstimo à sociedade no ato da subscrição do título, surgindo o direito de crédito representado no instrumento de dívida, com direito ao recebimento da prestação periódica que remunera o capital e a restituição deste com base no valor nominal inscrito no título. ${ }^{110}$

Portanto, as primeiras definições enxergavam na debênture uma relação bilateral decorrente de um contrato de mútuo, talvez por influência da teoria contratualista ${ }^{111}$. Com o advento dos estudos a respeito da teoria geral dos títulos de crédito, bem como em razão do disposto no art. 52 da LSA, que imputou ao titular das debêntures um direito de crédito em face da companhia, a doutrina passou a conceituar as debêntures também como um título de crédito.

Tavares Guerreiro e Egberto Teixeira, em célebre obra sobre as sociedades anônimas, colocaram as debêntures em uma categoria especial de mútuo ao considerarem a sua forma de emissão, em que o valor total do empréstimo é fracionado em partes iguais, na própria escritura, de modo a permitir que diversos interessados possam ser titulares de debêntures da mesma emissão. Distinguem-nas do mútuo comum em razão do modo de sua emissão, que exige aprovação em assembleia ou, atualmente, em reunião do conselho de administração, conforme as disposições da LSA, já que a contratação de empréstimo independe de autorização assemblear, via de regra, exceto nos casos em que há previsão estatutária nesse sentido. Ainda, reconhecem que as debêntures são "autênticos títulos de

\footnotetext{
${ }^{109}$ Commentario Delle Società. Tomo I. A cura di Giovanni Grippo. Coord. BERTACCHINI, Elisabetta et al. Turim: UTET, 2009, p. 685.

${ }^{110}$ Francesco Galgano (Tratattato di Diritto Commerciale e di Diritto Pubblico Dell'Economia. Vol. 29. Tomo I. $3^{\text {a }}$ ed. Padova: CEDAM, 2006, p. 677), defende que a obrigação tem a natureza de mútuo e cita a lição de Bonilini-Confortini (Codice civile ipertestuale, p. 4521), em que a obrigação é vista como um mutuo collettivo.

111 "Na história do direito cambiário brasileiro, até 1908, foi a concepção francesa que predominou, concepção que continuava e continuou agarrada à explicação contratualista." (MIRANDA , Pontes de. Tratado de Direito Cambiário. Letra de Câmbio. Vol I. São Paulo: Max Limonad, 1954, p. 15)
} 
crédito" por força de lei, tendo em vista que o art. 52 da LSA prevê um direito de crédito dos debenturistas em face da companhia. ${ }^{112}$

A doutrina italiana apresenta como noção de obrigação (ou debênture) um título de crédito que representa uma fração de igual valor nominal e com direitos iguais de uma única operação de financiamento a título de mútuo. ${ }^{113}$

Ascarelli explica que as debêntures revestem uma obrigação atribuída à sociedade emissora e que pode ter como causa um mútuo, sendo que o título pode ser distribuído independentemente da existência desse tipo de contrato, por meio da distribuição de debêntures aos próprios credores. Nesse caso, defende que a causalidade do título seria o pagamento de uma dívida e, por consequência, o recebimento da importância pela sociedade não significaria a celebração de um contrato de mútuo. O título não serviria, portanto, para a captação ou contratação de um empréstimo, mas se configuraria como instrumento de dação em pagamento de uma dívida, podendo, ainda, ser utilizado para a garantia de um débito próprio. ${ }^{114}$

Nessa linha, Luis de Angulo Rodríguez, ao discordar da teoria do mútuo, afirma que "a operación de emisión de obligaciones constituye un contrato sui generis, independiente y con peculiaridades proprias"115. Assim como Ascarelli, o jurista espanhol também reconhece que a emissão de debêntures pode se dar em razão de causas das mais diversas, não se limitando apenas à causa mutualística defendida por alguns doutrinadores.

Nas palavras de Miranda Valverde, “obrigações ao portador ou debêntures são termos que designam um título de crédito, que entra na categoria das obrigações por declaração unilateral de vontade" e "a denominação - obrigação ao portador ou debênture cabe somente ao título ou documento que contém a promessa de pagamento em dinheiro, com as declarações relativas aos direitos do portador e às obrigações do subscritor ou emissor." "116

\footnotetext{
${ }^{112}$ Das Sociedades Anônimas no Direito Brasileiro. Vol. 1. São Paulo: Bushatsky, 1979, p. 346.

${ }^{113}$ CAMPOBASSO, G.F. Diritto Commerciale. Diritto Delle Società. $6^{\mathrm{a}}$ ed. Turim: UTET Giuridica, 2007, p. 519.

${ }_{114}$ ASCARELLI, Tullio. Teoria Geral dos Títulos de Crédito. Campinas: Servanda, 2009, pp. 279-280.

${ }^{115}$ La Financiácion de Empresas Mediante Tipos Especiales de Obligaciones. Zaragoza: Cometa, 1968, pp. 1920.

${ }^{116}$ Ob. cit., p. 160.
} 
Como título de crédito, João Eunápio Borges ensina que as debêntures possuem os "atributos de autonomia e literalidade" e são consideradas títulos causais e incompletos, que não apresentam as características da independência e abstração, vinculandoas à escritura de emissão e ao contrato que se forma com a subscrição do título. ${ }^{117}$ Ascarelli, por sua vez, afirma que "a assunção do débito por obrigações constitui um negócio abstrato, em que não se pode, portanto, ver nem um mútuo, nem uma venda; a causa da obrigação (debênture) será diversa nos vários casos". 118

Por essa linha de raciocínio, as debêntures seriam títulos de crédito ${ }^{119}$ que revestiriam em sua base um contrato de mútuo, com divergência a respeito da causalidade ou abstração ${ }^{120}$ do título, como visto acima na doutrina brasileira e, também, apontado pelos italianos, como nos mostra Jaeger. ${ }^{121}$

As conceituações que imputaram às debêntures a natureza de mútuo ou título de crédito foram construídas em períodos anteriores à Lei $n^{\circ} 6.385$, de 07 de dezembro de 1976, e ao atual Código Civil (Lei $\mathrm{n}^{\circ}$ 10.406, de 10 de janeiro de 2002), com algumas exceções. ${ }^{122}$ Com isso, tem-se que o conceito e a natureza jurídica das debêntures carecem de atualização e aproximação à nova realidade do instituto, inserido legalmente na categoria dos valores mobiliários. A própria evolução da doutrina já tem colocado o instituto na categoria

\footnotetext{
${ }^{117}$ Ob. cit., p. 283.

118 Ob. cit., p. 281, nota de rodapé 76.

119 Ao conceituar a debênture como título de crédito, faz-se sob a ótica do debenturista, pois, a nosso ver, sob a ótica da sociedade emissora, as debêntures seriam títulos de dívida.

${ }^{120}$ Pontes de Miranda (Ob. cit., p. 12) esclarece que o título é abstrato "porque nele se abstrai da causa, não porque a vontade privada o tenha imposto, e sim porque a lei o quer. É abstrato por força de lei. Assim, além de direito autônomo, que adquire o possuidor, tem ele direito abstrato, com que a sua posição se fortalece, fazendoo livre do contágio de quaisquer causas das relações em que estiveram os possuidores precedentes". Ensina o mestre, ainda, que a abstração esteve na fundação das teorias alemãs, desde K. Einert.

121 "Le obbligazioni sono titoli di credito. È discusso se si tratti di titoli astratti o di titoli causali. Alcuni sostengono che il rapporto da cui sorgono le obbligazioni è único (da uma parte vi sarebbe la società e dall'atra il «grupo» degli obbligazionisti). Altri ritengono che esistono tanti contratti (e quindi tanti rapporti) quanti sono i titoli emessi." (JAEGER, Pier Giusto; DENOZZA, Francesco; TOFFOLETTO, Alberto. Appunti di Diritto Commerciale. Impresa e Società. $7^{\mathrm{a}}$ ed. Milão: Giuffrè, 2010, p. 263)

122 Ary Oswaldo Mattos Filho, ao examinar o conceito de valor mobiliário, explica que a doutrina insere o instituto historicamente no "tronco dos títulos de crédito" por influência do direito italiano, que os classificam em próprios ou impróprios, em que pese a distinção legal operada pela lei que criou a CVM e o "embaraço" criado pela conceituação da doutrina nacional, já que "o emprego da expressão valores mobiliários é utilizado pelos direitos francês, belga, inglês, norte-americano, enquanto toda a tradição brasileira é construída em função dos títulos de crédito" (O Conceito de Valor Mobiliário. Revista de Direito Mercantil, Industrial, Econômico e Financeiro. Ano XXIV. Nova Série. N. 59. São Paulo: Revista dos Tribunais, 1985, p. 34).
} 
de título abstrato de dívida, como mencionado por Tavares Borba ${ }^{123}$, ainda que tal classificação não seja por de todo completa.

A jurisprudência também não ficou para trás em matéria de evolução da natureza jurídica das debêntures. O STJ, por exemplo, recentemente, em voto do Ministro Luis Felipe Salomão, afirmou que as debêntures possuem certas peculiaridades que as diferenciam dos títulos de crédito, "tendo em vista que não assiste a tais valores mobiliários a autonomia, literalidade e cartularidade" ${ }^{124}$. Além disso, ao buscar o conceito do instituto na doutrina, o ilustre Ministro traz em seu voto citações de comercialistas ${ }^{125}$ que perfilham o entendimento de que as debêntures são valores mobiliários que conferem ao seu titular um direito de crédito em face da sociedade emissora, nas condições previstas na escritura de emissão. Portanto, modernamente, a jurisprudência caminha no sentido de diferençar as debêntures dos títulos de crédito, atribuindo-lhes o conceito de valores mobiliários que revestem um direito de crédito em face da sociedade emissora. ${ }^{126}$

Além disso, as debêntures têm vida própria e autônoma a partir da sua colocação no mercado, podendo assumir traços distintos entre as diversas séries de uma mesma emissão. Essa autonomicidade e serialidade do título faz com que as debêntures possam ter diversos tipos de relações jurídicas em sua base, e não apenas uma relação de crédito e débito, como veremos a seguir.

Em que pese as debêntures, via de regra, revelarem em sua base um contrato de mútuo $^{127}$, como um negócio jurídico bilateral, a doutrina, como se disse, reconhece a possibilidade de sua emissão ser motivada por outros negócios jurídicos. Alfredo Russel já ensinava, com base nas lições de Carvalho de Mendonça e Spencer Vampré, que "não é essencial que o produto do empréstimo entre efetivamente em dinheiro para a caixa da sociedade, mas que se possa destinar ao pagamento ou resgate de dívidas anteriores ou ao

\footnotetext{
123 Ob.cit., p. 20.

${ }^{124}$ Recurso Especial no 1.321 .243 - RJ (2012/0072888-9), Rel. Ministro Luis Felipe Salomão, $4^{\text {a }}$ Turma. Data do julgamento: 18/06/2013. Data da publicação: Dje 12/08/2013.

${ }^{125} \mathrm{O}$ voto cita as opiniões de Alfredo Lamy Filho e José Luiz Bulhões Pedreira, Modesto Carvalhosa, Fábio Ulhoa Coelho, Geraldo de Camargo Vidigal e Ives Gandra da Silva Martins.

${ }^{126}$ Recurso Especial n ${ }^{\circ}$ 1.321.243 - RJ (2012/0072888-9), Rel. Ministro Luis Felipe Salomão, $4^{\text {a }}$ Turma. Data do julgamento: 18/06/2013. Data da publicação: Dje 12/08/2013.

${ }_{127}$ Paulo Câmara esclarece que "o titular da obrigação é fundamentalmente um credor perante a entidade emitente e como relação jurídica subjacente na base deste valor mobiliário existe tipicamente um contrato de mútuo." (Manual de Direito dos Valores Mobiliários. Coimbra: Almedina, 2009, p. 141)
} 
pagamento de obras e serviços no interesse da sociedade, só não tendo valor jurídico a emissão para augmentar os benefícios dos sócios. Solvendo dúvida a respeito encontra-se um acórdão da $2^{\mathrm{a}}$ Câmara da Corte de Apelação o qual resolveu que é válida a emissão de debentures sem entrada em dinheiro correspondente quando essa emissão é feita para satisfazer serviços prestados e dívidas no interesse da sociedade". ${ }^{128}$

João Eunápio Borges, em sua clássica obra sobre títulos de crédito, registra que “embora resultante em geral de um empréstimo em dinheiro, Miranda Valverde considera inexata a afirmação dos que veem sempre e unicamente na base da emissão de debêntures um contrato de mútuo - inexatidão a que não fugiram as próprias leis que as disciplinam - uma vez que, por meio delas, o emissor pode praticar diferentes operações de crédito". ${ }^{29}$

Edmur de Andrade Nunes Pereira Neto salienta que "mesmo os mais fiéis seguidores da teoria do mútuo não resistiram a enxergar a existência de outros negócios jurídicos dando lugar à emissão de debêntures." ${ }^{\text {"130 }}$ Nelson Eizirik, em recente obra, comenta que "a criação da debênture é negócio jurídico unilateral, a sua emissão pode ser motivada por negócio distinto do mútuo, tal como os de permuta e dação em pagamento"131.

Há, também, a possibilidade de se emitir debêntures perpétuas que mais se aproximam de títulos de renda ou participação, cujo vencimento ocorre apenas em caso de inadimplemento do pagamento de juros ou dissolução da companhia, descaracterizando a obrigação de restituição da coisa emprestada em determinado prazo fixado pelas partes ou em lei. Sem falar, ainda, da hipótese de mantença das debêntures em tesouraria pela sociedade emissora, o que, certamente, levaria o título a perder a sua base mutualística, diante da inexistência de um direito de crédito, mesmo que temporariamente, em razão da superveniência dos efeitos da confusão entre emissor e subscritor.

Além disso, as debêntures conversíveis em ações podem gerar um direito de participação, e não apenas um direito de crédito, assim como admitir ao debenturista a participação nos lucros sociais. Ainda que o direito de participação esteja condicionado à sua conversibilidade, é patente a existência de uma outra causa que não a do mútuo. Em tal

\footnotetext{
${ }^{128}$ Sociedades Anonymas. $2^{\mathrm{a}}$ ed. Rio de Janeiro: Livraria Jacintho, 1937, pp. 516-517.

${ }^{129}$ Ob. cit., p. 281.

${ }^{130}$ Ob. cit., p. 35.

${ }^{131}$ A Lei das S/A Comentada. Vol. I. São Paulo: Quartier Latin, 2011, p. 320.
} 
hipótese, ainda que indiretamente, a causa poderia estar atrelada ao interesse da sociedade em alargar a sua base acionária, em data futura, por meio da conversão das debêntures em ações, o que poderia ocorrer, por exemplo, para assegurar vantagem aos titulares das debêntures de receber os juros previstos na escritura, enquanto a sociedade não pudesse declarar dividendos.

Portanto, a nosso ver, não há como categorizar a debênture como espécie de contrato de mútuo, como se fazia anteriormente. Enquadrá-la naquilo que se revela em sua base, sem considerar as suas características próprias, é inverter a lógica que nos leva a caracterizar uma espécie em determinada categoria jurídica.

Por outro lado, não se busca neste trabalho afastar por completo as debêntures dos títulos de crédito - já que é inegável a importância da doutrina dos títulos para a construção teórica atual, como veremos adiante -, mas sim de aproximá-las da categoria dos valores mobiliários, levando-se em conta a evolução do direito nesse campo. ${ }^{132}$ Discorrer-seá, assim, sobre o encadeamento lógico da doutrina em sua conceituação e classificação dos títulos de crédito, que, de antemão, fora inspirada nas doutrinas italiana e francesa.

De início, é imperioso reconhecer, como nos ensina Ascarelli ${ }^{133}$, que o instituto dos títulos de crédito é o que mais influenciou a formação da economia moderna, facilitando a mobilização das riquezas e assegurando a certeza do crédito e a segurança jurídica de sua satisfação. Tal feito do direito comercial resolveu os problemas da transmissão do crédito e da desvinculação das relações jurídicas. ${ }^{134}$ As debêntures se aproveitaram dessa construção

\footnotetext{
${ }^{132}$ Edgar Jelonche, ao examinar os valores mobiliários no Mercosul, explica que "las especies clásicas, como la cambial y los títulos de empréstito al portador, se conocian ya bastante cuando se inició la codificación napoleónica, la noción de título-valor todavia no existia; su gestación se daba en la doctrina germana, que no era paradigma de la legislación en ese entonces. El derecho francés desarrolló simultáneamente las categorias de los efectos de comercio y de los valores mobiliarios, que ha mantenido hasta hoy sin conformar una teoría que abarque a unos y otros." (Mercosur y Valores Mobiliarios. In: Simpósio sobre Direito dos Valores Mobiliários. Série Cadernos do Conselho da Justiça Federal. N. 16. Brasília: CJF, 1999, p. 33)

${ }_{133}^{133}$ Ob. cit., p. 33.

${ }^{134}$ Waldemar Ferreira recorda que os títulos de crédito - documento escrito que reconhece uma dívida com obrigação de pagamento a prazo - são comuns na prática jurídica e encontram suas raízes nos vales e clarezas, citando as Ordenanzas de la Ilustre Universidad y Casa de Contratación de la Villa de Bilbao, de 1459, como exemplo de norma que disciplinava os vales, desde o Século XV. Segue o notável jurista, em sua construção histórica, com a notícia de que o Código Civil Francês, apesar de propugnar pela livre manifestaçao de vontade no plano obrigacional, era contrário à obrigação sem causa ou fundada em falsa causa, tornando-a ineficaz. Privilegiava-se a causa, em que pese a forma adotada pelo escrito, sendo aquela "condição substancial, ainda mesmo que a declaração da vontade se concretize em escrito revestido das formalidades legais. A forma deste é relevante, mas insuficiente para por si só legitimar a obrigação." Por tal razão, reconhece Waldemar Ferreira, que o documento de confissão de dívida, mesmo considerado como título de crédito, era eminentemente causal e não possuía a abstração necessária para lhe assegurar a rápida circulação. (Instituições de Direito Comercial. Vol. 3. Tomo I. $4^{\text {a }}$ ed. São Paulo: Max Limonad, 1958, pp. 40-45).
} 
jurídica para justificar a sua circulação nos países de tradição romano-germânica, já que em sua origem, assim como até hoje, tal discussão é totalmente irrelevante nos países de common law, cuja tradição, desde sempre, foi considerá-las espécie da categoria securities (valores mobiliários).

Essencial foi a lição de Vivante, atribuindo aos títulos de crédito existência material, cuja exibição é necessária para o exercício do direito, incorporado no título, a partir de sua célebre definição: "é título de crédito o documento necessário para exercer o direito literal e autônomo nele mencionado". 135 e 136

Luigi Lordi, jurista napolitano, em obra anterior à unificação do direito privado italiano, classificava os títulos de crédito na categoria das obrigações comerciais, reconhecendo, porém, a liberdade de sua emissão em matéria civil. Para ele, as características relevantes do instituto eram as seguintes: "la funzione costitutiva del documento; la singolarità del trasferimento, che spesso trasferisce più di quanto potrebbe l'alienante". ${ }^{137}$ Muito à frente, todavia, a doutrina passou a reconhecer que "os títulos de crédito são documentos dispositivos, e não simplesmente constitutivos de direitos", cuja função genérica é a de "facilitar a circulaçao dos direitos ou da situação jurídica por eles materializada, ou seja, a sua negociabilidade". ${ }^{138}$

Waldemar Ferreira recorda que o Código de Comércio de França "cuidou todavia do que chamou de effets de commerce, sem os definir, tão pouco enumerar", cabendo aos tratadistas da época assim defini-lo: "todo título, todo escrito recebido correntemente em pagamento nas condições comerciais, no lugar e em vez da moeda, sem apresentar no entanto

\footnotetext{
${ }^{135}$ Traduzido do original: "Il titolo di credito è un documento necessario per esercitare il diritto letterale ed autonomo che vi è menzionato." (Trattato di Diritto Commerciale. Vol. III. 4a ed. Milão: Dottor Francesco Vallardi, 1914, pp. 163-164). Ninguém melhor do que o próprio Vivante (Ob. cit., p. 164) para explicar os elementos de sua definição: "Si dice che il dirittoè autonomo, perchè il possessore di buona fede esercita un diritto proprio, che non può essere ristretto o distributto dai rapporti corsi fra i precedenti possessori e il debitore. Si dice che il titolo è il documento necessario per esercitare il diritto, perchè fino a quando il titolo esiste, il creditore deve esibirlo per esercitare ogni diritto, sia principale sia acessorio, che esso porta con se. Questo è il concetto giuridico, preciso e limitato, che deve sostituirsi alla frase volgare, per cui s'insegna che il diritto è incorporato nel titolo. Quando il titolo sia stato distrutto o annullato cessa la necessità di quel vincolo fra il documento e il diritto, cessa quella cosidetta incorporazione e il diritto può esercitarsi anche senza di esso."

${ }^{136}$ Os títulos de crédito são disciplinados, atualmente, no Título VIII, do Livro I (Direito das Obrigações), da Parte Especial, do Código Civil vigente, e seu conceito está positivado da seguinte maneira: “o título de crédito, documento necessário ao exercício do direito literal e autônomo nele contido, somente produz efeito quando preencha os requisitos da lei" (art. 887, CC).

${ }^{137}$ Le Obbligazioni Commerciali. Nápoles: Nicola Jovene \& C. Editori, 1933, p. 221.

${ }^{138}$ COMPARATO, Fábio Konder. Direito Empresarial. Estudos e Pareceres. São Paulo: Saraiva, 1990, p. 462.
} 
os atributos de verdadeira moeda, é um efeito de comércio". ${ }^{139}$ As características comuns dos efeitos de comércio foram também arroladas pelo ilustre comercialista, com base no trabalho de P. Lescot \& R. Roblot, da seguinte forma:

\begin{abstract}
“a) são títulos negociáveis, isto é, emitidos à ordem ou ao portador, assegurandolhes essa negociabilidade sua circulação rápida;

b) devem conter a indicação de seu valor, pois nenhum título pode desempenhar o papel da moeda sem que mencione seu valor relativamente a esta moeda, isto é, a quantidade de espécies metálicas ou de notas de banco contra as quais seu possuidor pode trocá-los;

c) têm que referir sempre um crédito de soma de dinheiro, porque somente os escritos ministrando ao portador o direito de exigir diretamente do devedor, em vencimento determinado, certa soma, podem circular livremente;

d) o crédito há de ser a curto prazo, de sorte que o portador possa trocá-los imediatamente com numerário em qualquer banco que se disponha a descontá-los, isto é, de fazer um adiantamento de seu montante, antes de seu vencimento, mediante a dedução de certo juro ou parcela, que é o desconto." ${ }^{140}$
\end{abstract}

Muitos títulos se encaixam perfeitamente na categoria dos efeitos de comércio $^{141}$, tais como as letras de câmbio ${ }^{142}$ e as notas promissórias ${ }^{143}$. Todavia, as ações e as obrigações são títulos que preenchem algumas das características comuns, mas que não as satisfazem por completo, sendo excluídas, consequentemente, da referida categoria, como ensina Waldemar Ferreira. ${ }^{144}$

É, porém, na separação feita entre títulos em série e individuais, extraída da obra de Ascarelli ${ }^{145}$, que podemos chegar ao quadro classificatório que nos permite inserir as debêntures em categoria distinta da dos títulos de crédito stricto sensu.

\footnotetext{
${ }^{139}$ Ob. cit., p. 50.

${ }^{140}$ Ob. cit., p. 51.

141 "Como é de imaginar, mercê da influência do Código de Comércio de França na elaboração do código brasileiro, este também se serviu, [...], da expressão efeitos de comércio, em mais de um texto, com o mesmo significado, a despeito de ter-lhe dado sentido muito mais amplo de modo a abranger até as mercadorias e outras utilidades suscetíveis de negócio”. (Waldemar Ferreira, ob. cit., p. 51)

142 "Entende-se por letra de câmbio uma ordem dada, por escrito, a uma pessoa, para que pague a um beneficiário indicado, ou à ordem deste, uma determinada importância em dinheiro". (MARTINS, Fran. Títulos de Crédito. $15^{\mathrm{a}}$ ed. Rio de Janeiro: Forense, 2010, p. 27). A origem do instituto é desconhecida, porém a doutrina noticia sua existência a partir da Idade Média. Fran Martins (Ob. cit., p. 28) explica que "costuma a história desse título ser dividida em três períodos, o primeiro chamado de período italiano, que vai da Idade Média ao último quartel do século 17; o segundo, período francês, das Ordenanças de Comércio, de 1673, até meados do século 19; e o último, período alemão, de 1848 aos dias atuais".

143 "Entende-se por nota promissória a promessa de pagamento de certa soma em dinheiro, feita, por escrito, por uma pessoa, em favor de outra ou à sua ordem". (Fran Martins, ob. cit., p. 261).

${ }_{144}^{144}$ Ob. cit., p. 51.

145 Ascarelli produziu quatro artigos publicados na Itália, em 1932, na Rivista di Diritto Commerciale, de Milão. Os estudos foram elaborados "com o fim de indagar, através da disciplina positiva dos vários títulos de crédito, os seus princípios jurídicos básicos e gerais” (Ascarelli, ob. cit., p. 11), tendo sido traduzidos, posteriormente,
} 
Os títulos emitidos em série, ou em massa, são objeto de disciplina comum e conferem os mesmos direitos a seus titulares, dentro da mesma série. Classificam-se como títulos fungíveis e, normalmente, servem para pagamento em longo prazo, atribuindo, muitas vezes, em contrapartida, o direito à prestação periódica, além do reembolso do principal. Já nos títulos individuais, ou singulares, "a criação de cada título acompanha um negócio distinto, e o direito mencionado em um título pode divergir (no seu valor, vencimento, etc.) do direito mencionado (por exemplo, cambial)". ${ }^{146}$ Estes, por sua vez, são classificados como títulos infungíveis, utilizados para pagamento em curto prazo e que, por tal razão, não preveem o direito à prestação periódica.

Outra distinção marcante se faz em relação ao local de negociação dos títulos. Enquanto os títulos em série são formatados para negociação em mercados organizados (bolsas de valores ou mercados de balcão), os títulos individuais são negociados perante instituições financeiras ou particulares, não sendo admitidos naqueles mercados, o que restringe a sua circulação.

Por tais razões, conclui Ascarelli, que os títulos em série são "considerados como valores (valeurs mobilières na terminologia francesa, em oposição aos effets de commerce), objeto de aplicação de capital e especulação."147

Nessa mesma linha seguiu Comparato, ao examinar a natureza dos títulos da dívida agrária, para quem "os valores mobiliários possuem, como diferença específica em relação aos títulos de crédito stricto sensu, o fato de serem sempre emitidos em série, tendo os títulos de cada série características idênticas. Daí decorre que, dentro da mesma série, os valores mobiliários são economicamente fungíveis: pelo fato de terem a mesma cotação, eles podem ser substituídos, uns pelos outros, sem qualquer variação de ordem econômica." 148

Assevera, ainda, que "a característica da fungibilidade econômica dos valores mobiliários torna-os autênticas mercadorias, ou seja, coisas suscetíveis de negociação e cotação num mercado. E esta é outra diferença importante, relativamente aos títulos de crédito

para o português e reproduzidos, conjuntamente, na obra que veio a ser intitulada Teoria geral dos títulos de crédito.

${ }^{146}$ Ascarelli, ob. cit., p. 528.

${ }^{147}$ Ob. cit., p. 529.

148 Ob. cit., p. 463. 
stricto sensu." ${ }^{149}$ Em linha com a escola francesa, Comparato ilumina o caminho percorrido pela doutrina e nos faz enxergar com clareza a categoria à qual pertencem as debêntures: "dentro da categoria geral dos títulos de crédito distinguem-se duas espécies: os títulos de crédito stricto sensu ou effets de commerce, segundo a denominação tradicional francesa, e os valores mobiliários". 150

Nota-se, portanto, que a característica decisiva para concluir que as debêntures são valores mobiliários, e não títulos de crédito stricto sensu, é a sua serialidade, a sua emissão em conjuntos homogêneos ou em massa. Amadeu Ferreira, citando Paolo Spada, esclarece que, "enquanto nos títulos emitidos individualmente é adotada uma perspectiva micro-jurídica (relação titular-adquirente), nos valores mobiliários está presente uma perspectiva macro-jurídica (relação emitente/mercado-investidores).”

O direito português vincula a evolução da natureza das obrigações ou debêntures à cártula. Paulo Olavo Cunha explica que "classicamente - e sobretudo quando estes valores mobiliários eram necessariamente documentados em papel -, dizia-se simplesmente que as obrigações eram títulos de dívida”. Com a desmaterialização dos títulos, as obrigações se aproximaram ainda mais da definição de valores mobiliários, superando aquela clássica conceituação de título de crédito que tem na base um contrato de mútuo.

Florbela de Almeida Pires, em obra coordenada por Menezes Cordeiro, afirma que as obrigações “autonomizam-se dos títulos de crédito através do seu regime próprio, no contexto do direito dos valores mobiliários. As obrigações são um dos valores mobiliários de referência $[\ldots] . " 151$

Retornando ao direito brasileiro, Ary Oswaldo Mattos Filho ensina que a construção teórica dos títulos de crédito não é mais suficiente para explicar o fenômeno jurídico que resulta da criação de títulos ou valores mobiliários:

\footnotetext{
${ }^{149}$ Ob. cit., p. 464.

${ }^{150}$ Ob. cit., p. 463.

151 Código das Sociedades Comerciais Anotado. Coord.: CORDEIRO, António Menezes. 2 ${ }^{\mathrm{a}}$ ed. Coimbra: Almedina, 2012, p. 929.
} 


\begin{abstract}
“O aumento dos 'credores' da relação obrigacional oriunda do direito cartular retirou parcialmente a autonomia que originariamente se concebeu como característica fundamental dos títulos de crédito. A relação originária, nos títulos de massa, pode, em determinadas circustâncias, ser alterada sem consentimento do credor, através de uma decisão majoritária ocorrida em assembleia geral de acionistas ou de debenturistas. Ou seja, a relação cartular não é literal, e a relação obrigacional pode ser alterada sem a vontade do credor. Passa a inexistir a literalidade do título, e em algumas hipóteses, nem mesmo a cártula necessita existir para que o direito se materialize.

De outro lado os títulos emitidos por uma sociedade, quer aqueles de participação, quer os de empréstimo, bem como os subprodutos destes, resultam de um contrato; que será ou o contrato social, no caso das ações, ou a escritura de emissão, na hipótese de debêntures. Tal situação contraria a teoria dos títulos de crédito, segundo a qual o direito autônomo, oriundo da promessa cambial, é entendido como um ato unilateral do subscritor, e não uma obrigação oriunda de vínculo contratual entre o emitente e o tomador." 152
\end{abstract}

Newton de Lucca, por sua vez, é categórico em sua afirmação de que "o conceito de valores mobiliários não possui qualquer liame lógico com o de 'títulos de crédito'. ${ }^{153}$ Para ele, inexiste "uma relação de gênero e espécie entre os títulos de crédito e os valores mobiliários, pois o que faz determinado papel vir a ser considerado, eventualmente, um valor mobiliário é algo inteiramente diverso do que o leva a categorizá-lo como sendo um título de crédito". ${ }^{154}$ Não restam dúvidas, portanto, que as debêntures não se encaixam na disciplina dos títulos de crédito. Cumpre, agora, analisar o conceito de valores mobiliários tarefa das mais intrincadas -, para melhor compreender a categoria à qual pertencem as debêntures.

Em nosso direito positivado, a Lei $\mathrm{n}^{\circ} 4.728 / 65$ foi a primeira a se utilizar das expressões "valor mobiliário" e "título mobiliário", sem diferençá-las ou conceituá-las. Aproveitando-se da experiência norte-americana, a Lei ${ }^{\circ}$ 6.385/76 relacionou as espécies de valores mobiliários sujeitos à fiscalização da CVM, deixando, contudo, de fornecer os elementos para a sua conceituação.

Ary Oswaldo Mattos Filho foi um dos pioneiros a se debruçar sobre o conceito de valor mobiliário. Em notável artigo sobre o tema, anteriormente citado, relaciona os elementos caracterizadores de um valor mobiliário, a seguir sintetizados: (a) contribuição

\footnotetext{
152 Ob.cit., p. 35.

${ }^{153}$ As Bolsas de Valores e os Valores Mobiliários. In: Simpósio sobre Direito dos Valores Mobiliários. Série Cadernos do Conselho da Justiça Federal. N. 16. Brasília: CJF, 1999, p. 131.

${ }^{154}$ Newton de Lucca, ob. cit., p. 132.
} 
para o investimento: é a entrega de dinheiro ou bem suscetível de apreciação econômica; (b) empreendimento comum: é a gestão do empreendimento por terceiro, com ou sem participação do investidor, cujo "fundamento da comunhão é a existência de interesse econômico interligado juridicamente"; (c) expectativa de lucro: é a esperança de receber a mais valia - benefício econômico oriundo do contrato de investimento de risco - a partir da gestão do empreendimento por terceiro; (d) caracterização do empreendimento: é a substância do negócio jurídico e o seu fundamento econômico que o caracterizam como valor mobiliário, e não apenas o seu nome; (e) contrato de risco: "possibilidade de perda econômica" do investimento realizado atrelado ao risco do empreendimento comum; (f) controle do empreendimento: inexiste poder de decisão do investidor sobre o investimento ou empreendimento comum; (g) materialização do valor mobiliário: o investimento realizado pode ou não se corporificar em um documento que represente a relação jurídica, porém gera direitos e obrigações para as partes envolvidas; e (h) falta de especialização: espera-se que o gestor dos recursos tenha o conhecimento necessário para realizar os investimentos. $^{155}$

Conclui, por fim, com o seguinte conceito de valor mobiliário: “é o investimento oferecido ao público, sobre o qual o investidor não tem controle direto, cuja aplicação é feita em dinheiro, bens ou serviço, na expectativa de lucro, não sendo necessária a emissão do título para a materialização da relação obrigacional". ${ }^{156}$

Rita de Cássia Luz Teixeira Motta, em dissertação sobre o tema, assevera que “a concepção atual de valores mobiliários privilegia o caráter de oferta pública de investimento das operações assim consideradas, aliado ao caráter massificado da respectiva emissão, em detrimento da forma em que são ofertados ou da pessoa do agente emissor". ${ }^{157}$ Nota-se, portanto, mais uma vez, a presença da serialidade - a sua emissão em conjuntos homogêneos ou em massa -, como elemento caracterizador dos valores mobiliários e, consequentemente, das debêntures como espécie de tal categoria.

\footnotetext{
${ }^{155}$ Ob. cit., pp. 41/46.

${ }_{156}^{156}$ Ary Oswaldo Mattos Filho, ob. cit., p. 49.

${ }^{157}$ O Conceito de Valor Mobiliário no Direito Brasileiro. Dissertação de Mestrado apresentada à Faculdade de Direito da Universidade de São Paulo, 2002, p. 105.
} 
No âmbito legislativo, foi a Medida Provisória ${ }^{\circ}$ 1.637/98, editada mais de 20 anos após a criação da CVM, que introduziu o conceito de valores mobiliários em nosso ordenamento jurídico, a saber:

\begin{abstract}
“Art. $1^{\circ}$. Constituem valores mobiliários, sujeitos ao regime da Lei $n^{\circ} 6.385$, de 7 de dezembro de 1976, quando ofertados publicamente, os títulos ou contratos de investimento coletivo, que gerem direito de participação, de parceria ou de remuneração, inclusive resultante de prestação de serviços, cujos rendimentos advém do esforço do empreendedor ou de terceiros."
\end{abstract}

Tal conceito foi reproduzido pela Instrução CVM n 270/98, no parágrafo único do art. $1^{\circ}$, na esteira de atualização da Lei $\mathrm{n}^{\circ}$ 6.385/76, compatibilizando-a com o direito norte-americano. ${ }^{158}$ Além de conceituar valor mobiliário, a CVM, em diversos pareceres $^{159}$, um deles anterior à referida Medida Provisória, destaca as seguintes características essenciais:

(a) Necessidade de proteção dos investidores, mediante divulgação de informações aos detentores dos títulos ou valores mobiliários (princípio do full disclosure);

(b) Instrumentalidade - para assegurar o intervencionismo estatal e o controle do mercado;

(c) Serialidade - títulos negociados em massa, de fácil e ampla circulação;

(d) Circulabilidade - é a possibilidade de circulação do valor mobiliário;

(e) Transferibilidade - "é requisito intrínseco ao caráter dos valores mobiliários de títulos emitidos em massa e amplamente negociados". 160

\footnotetext{
158 "A caracterização de securities na jurisprudência norte-americana teve como principal ponto de partida a definição de investment contract, havendo a Suprema Corte apreciado a questão, pela primeira vez, em 1943, no julgamento do caso SEC v. C.M. Joiner Leasing Corporation. [...] Aponta-se como leading case da conceituação de investments contracts o famoso julgamento, ocorrido nos Estados Unidos, em 1946, do caso SEC v. W.J.Howey \& Co. [...] Conforme a Howey definition, a security compreende o investimento de dinheiro em um empreendimento comum, no qual a expectativa de lucros depende unicamente dos esforços de terceiros". (EIZIRIK, Nelson et. al. Mercado de Capitais. Regime Jurídico. $3^{\text {a }}$ ed. Rio de Janeiro: Renovar, 2011, pp. 3234).

${ }^{159}$ Pareceres CVM/SJU n ${ }^{\circ}$ 36/79 e CVM/PJU n 09/98, citados por Rita de Cássia Luz Teixeira Motta (Ob. cit., p. 107).

${ }^{160}$ Cf. Rita de Cássia Luz Teixeira Motta, ob. cit., pp. 108-110.
} 
Percebe-se que as debêntures apresentam todas as características intrínsecas ao conceito de valor mobiliário, sendo inegável sua compatibilidade com o referido instituto. Enquadram-se, dessa forma, na categoria dos valores mobiliários não somente por definição legal ${ }^{161}$, mas também em razão de sua natureza.

Diante de tudo o que foi dito acima, pode-se concluir que a debênture tem a natureza de valor mobiliário, representada por um título de dívida, emitido em série, que legitima o seu titular ao exercício dos direitos nele revelados ${ }^{162}$, e que tem por função o financiamento da empresa, dispersando os credores e permitindo a sua livre negociação em mercado organizado e especializado, podendo adotar, em razão de sua tipicidade, os seguintes modelos: simples, conversível em ações ou permanente.

Com relação ao conceito de debêntures, resgatando a definição dada por Paul Simonson, tem-se que qualquer instrumento por meio do qual se cria, se convenciona a criação de, ou que se reconhece uma dívida em favor de uma ou mais pessoas, naturais ou jurídicas, é uma debênture. ${ }^{163}$

Francisco Müssnich, em recente artigo publicado na obra em homenagem ao Professor Tavares Guerreiro, traz a seguinte definição de debêntures: "são valores mobiliários representativos de dívida que asseguram a seus detentores direito de crédito contra a companhia emissora, nas condições constantes da escritura de emissão." 164

\footnotetext{
${ }^{161}$ A par dos conceitos doutrinários sobre a sua natureza, a Lei $n^{\circ} 6.385 / 76$, que dispõe sobre o mercado de valores mobiliários, estabelece em seu artigo $2^{\circ}$ que as debêntures e as cédulas de debêntures são consideradas valores mobiliários por definição legal, sujeitando-se ao regime jurídico previsto naquela lei quando houver a emissão, distribuição, negociação ou intermediação no mercado de valores mobiliários.

${ }^{162}$ Para a doutrina portuguesa, "o título ou registro relativos aos títulos dão-nos a legitimidade para o exercício dos direitos: ela assiste a quem, pelo título ou pelo registro, couberem os direitos relativos ao valor mobiliário considerado (55.\%1). São direitos inerentes aos valores mobiliários, designadamente (55. $\% 3)$ : $a$ ) os dividendos, os juros e outros rendimentos; $b$ ) os direitos de voto; $c$ ) os direitos à subscrição ou aquisição de valores mobiliários do mesmo ou diferente tipo." (Menezes Cordeiro, ob. cit., p. 636).

${ }^{163}$ Tradução do original (Paul Simonson, ob. cit., p. 5): "Any instrument (other than a covering deed) which either creates or agrees to create a debt in favour of one person (including joint holders) or corporation, or acknowledges such debt, is a debenture." Edward Manson apresenta definição um pouco mais completa: "A debenture is an acknowledgment of indebtedness by a company - under seal, and being one of a series ranking pari passu - by which the company agrees to pay the lender or holder for the time being of the security the amount of the loan at some future date, with interest until payment, and charges with the payment thereof the company's undertaking and assets by way of floating security." (Ob. cit., pp. 38-39).

${ }^{164}$ As recentes alterações com respeito à competência para emissão de debêntures. In: Direito Empresarial e outros estudos em homenagem ao Professor José Alexandre Tavares Guerreiro. Coord.: CASTRO, Rodrigo R. Monteiro de; WARDE JÚNIOR, Walfrido Jorge; e GUERREIRO, Carolina Dias Tavares. São Paulo: Quartier Latin, 2013, p. 539.
} 
Verifica-se, assim, que o conceito e a natureza jurídica das debêntures têm sido objeto de atualização constante pela doutrina, tendo em vista a evolução histórica dos institutos que serviram, ou ainda servem, de parâmetro para a interpretação da base, do alicerce, e das características que fundam as debêntures. Novos regimes jurídicos, a exemplo da definição do instituto como valores mobiliários, também contribuíram para que o instituto deixasse de ser visto apenas como um mútuo ou um título de crédito, sob o olhar do credor ou da teoria contratualista, para ser examinado sob a ótica do direito societário, como um título primordialmente revelador de um instrumento de dívida emitido em série para financiamento da sociedade - inicialmente da anônima, que foi o primeiro tipo societário de natureza privada a emitir obrigações ou debêntures.

Nesse sentido, é a definição encontrada nas obras dos doutrinadores ingleses e norte-americanos, construída a partir da ótica do direito societário, que parte da análise das debêntures como um instrumento de dívida que representa frações ou unidades do débito consideradas parte de um todo unitário - é o fenômeno da serialidade. Diferentemente das conceituações francesas ou italianas, que foram inspiradas nos títulos de crédito e partem da visão do credor, isto é, do sujeito que passa a ser o titular de uma fração daquele valor mobiliário já emitido, os criadores do instituto constroem as definições a partir da sociedade, do devedor, ou seja, do sujeito que dá origem ao título de dívida - é a visão funcional do instituto.

Ainda, como visto acima, a emissão de debêntures pode ocorrer em razão de uma causa justificadora distinta daquela utilizada para conceituar o título como um mútuo ou título de crédito. Como exemplo, temos as debêntures emitidas em uma operação de reorganização societária, cuja origem ou causa de sua emissão não é o mútuo, e, nas conversíveis, até mesmo a aquisição de controle por meio de diluição dos demais acionistas quando da conversão das debêntures em ações.

Os próprios autores da LSA, Lamy Filho e Bulhões Pedreira, ao explicarem o tratamento inovador dado às debêntures na nova lei das sociedades por ações, de modo diverso daquele então vigente sob os Decretos-lei n ${ }^{\circ}$ s. 177-A/1.893 e 781/1.938, afirmam categoricamente que "o título manteve sua natureza de título de dívida"165.

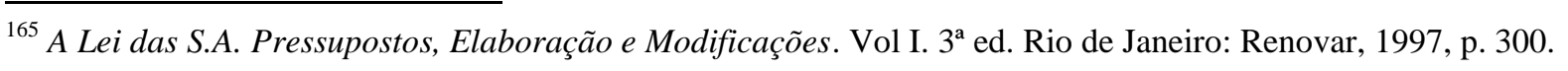


O Código de Sociedades francês, como visto anteriormente, categoriza os instrumentos financeiros em duas espécies: títulos financeiros ou contratos financeiros. Os títulos financeiros, por sua vez, compreendem os títulos de capital emitidos pelas sociedades por ações e os títulos de dívida. ${ }^{166}$ Portanto, o direito francês também reconhece que as obrigações são títulos de dívida que pertencem à categoria dos títulos financeiros, espécie do gênero instrumentos financeiros.

Ripert e Roblot conceituam as debêntures (obligations) da seguinte forma: “As obrigações são títulos negociáveis, emitidos por uma sociedade que necessita tomar emprestado importante soma de capital, geralmente a longo prazo, cuja dívida é fracionada em um grande número de cupons". ${ }^{167}$

Paulo Olavo Cunha define as debêntures (chamadas obrigações no direito português) da seguinte forma: “As obrigações são valores negociáveis que, numa mesma emissão, conferem um determinado direito de crédito ao seu titular e concedem direitos de crédito iguais para um idêntico valor nominal, correspondendo a um meio de financiamento da própria sociedade que exprime uma relação completamente diferente da relação de participação social."

\footnotetext{
${ }^{166}$ DEBOISSY, Florence; e WICKER, Guillaume. Code des Societies et Autres Groupements. $6^{\mathrm{a}}$ ed. Paris: LexisNexis, 2012, p. 845.

${ }^{167}$ Tradução livre e adaptada do seguinte texto: "Les obligations sont des titres négociables, émis par une société qui emprunte un capital important, généralement à long terme, et divise as dette en un grand nombre de coupures." (Ob. cit., p. 593).

${ }^{168}$ Ob. cit., p. 393. Interessante destacar que o referido jurista reconhece a conferência de direitos iguais para um idêntico valor nominal, o que nos leva a pensar, de modo inverso, sobre a possibilidade de direitos distintos para valores nominais diferentes, ou seja, sob o prisma do direito brasileiro, seria a igualdade de direitos dentro de uma série e a possibilidade de distinção entre as diversas séries. Tal raciocínio nos leva à reflexão sobre a desconstrução da teoria da massificação ou padronização do título debenturístico, já que o mesmo poderá diferenciar os direitos de cada série. É o que também podemos depreender da leitura inversa do parágrafo único do art. 53, da LSA ("As debêntures da mesma série terão igual valor nominal e conferirão a seus titulares os mesmos direitos"), ou seja, as debêntures de diferentes séries poderão conferir direitos específicos dentro de cada série. Parece-nos que esta é uma das características distintivas mais relevantes das debêntures em face dos demais valores mobiliários, aproximando-as das ações - que também podem ser emitidas com classes diferentes, conferindo direitos específicos aos seus titulares. As partes beneficiárias, por exemplo, não podem ser criadas com mais de uma classe ou série (art. $46, \S 4^{\circ}$, da LSA). Não há vedação ou previsão expressa para a emissão de bônus de subscrição em diferentes classes ou séries. Por força de interpretação da LSA, parece-nos ilógico permitir a criação de séries distintas de bônus de subscrição dentro de uma mesma emissão. Reforçando essa tese, o parágrafo único do art. 78 sujeitou os bônus de subscrição, supletivamente, ao regime jurídico aplicável às ações apenas no tocante aos certificados (Seção V), propriedade e circulação (Seção VI) e constituição de direitos reais e outros ônus (Seção VII), não remetendo expressamente às disposições da Seção III, do Capítulo III, que regem as espécies e classes de ações.
} 
É inegável, dessa feita, conceituar as debêntures como títulos ou valores mobiliários de dívida, emitidos em série, que têm por função o financiamento da sociedade para o desenvolvimento da empresa. 


\section{ESPÉCIES E GARANTIAS}

Título complexo, por natureza, que permite à companhia buscar recursos junto ao mercado para o financiamento de suas atividades, a debênture é um instrumento que pode ser moldado de acordo com as necessidades da sociedade emissora por meio de três espécies definidas em lei ${ }^{169}$, as quais se distinguem, basicamente, pelas causas que motivam a sua extinção, vez que pouco se diferenciam em seu modo de emissão.

No direito italiano, ainda, Luca Pisani ${ }^{170}$ destaca que as reformas ${ }^{171}$ realizadas na fattispecie obbligazionaria tiveram como objetivo dar mais atratividade aos títulos obrigacionais perante o público investidor, alargando os modelos especiais dos títulos. E é também a partir da flexibilização do título obrigacional aqui no Brasil ${ }^{172}$, que se nota o crescente aumento de emissões, não mais restritas às debêntures simples, mas pelo uso cada vez mais frequente de outras espécies, tais como os títulos perpétuos e os conversíveis em ações.

Inicialmente, as debêntures eram utilizadas como instrumentos puramente financeiros e, portanto, não admitiam a sua conversibilidade em ações. As debêntures simples, ou não conversíveis, eram típicos instrumentos de dívida, revestidos das características afeitas

\footnotetext{
${ }^{169}$ Debêntures simples, debêntures perpétuas e debêntures conversíveis em ações.

${ }^{170}$ Le obbligazioni. In "Il Nuovo Diritto Delle Società". Liber Amicorum Gian Franco Campobasso. Org.: ABBADESSA, P.; e PORTALE, G.B. Vol. 1. Turim: UTET Giuridica, 2007, p. 807. Texto original: "Come accennato in premessa, la riforma ha inteso conferire piena legittimità ad alcuni tipi speciali di obbligazioni, le cui caratteristiche mirano nella maggior parte dei casi ad incrementare l'appetibilitità di tali titoli agli occhi dei risparmiatori. Se infatti sinora le uniche ad essere previste e disciplinate dall'ordinamento erano le obbligazioni convertibili in azioni con procedimento diretto, il legslatore ha colto l'ocasione della riforma per estendere l'area dei tipi disciplinati - o forse sarebble meglio dire esplicitamente amessi, considerato che non viene dettata alcuna regola specifica - così ulteriormente confermando, e per taluni versi estendendo, l'elasticità della fattispecie obbligazionaria."

${ }^{171}$ Francesco Giancola (Ob. cit., p. 685), ao comentar o art. 2410 do Código Civil Italiano, destaca que "l'intervento normativo è stato dettato dall'esigenza e dalla volontà di favorire l'emissione di obbligazioni, come del resto confermato dalla lett. d) del $6^{\circ}$ co. dell'art 4, l. 3.10.2011, n. 366 che ha attribuito al Governo la delega per «modificare la disciplina relativa alla emissione di obbligazioni, attenuandone o rimuovendone $i$ limiti e consentendo all'autonomia statutaria di determinare l'organo competente e le relative procedure deliberative»."

${ }_{172}$ A Lei $\mathrm{n}^{\circ} 12.431$, de 24 de junho de 2.011, introduziu mudanças significativas no Capítulo V, Das Debêntures, da Lei 6.404/76, especialmente no que tange ao limite de emissão, com a supressão do art. 60 , retirando-o do ordenamento jurídico, fazendo com que as debêntures não estejam mais limitadas ao capital social da companhia. Tal mudança foi além daquelas verificadas na Itália que, neste caso, optou por elevar o limite para as debêntures simples, mantendo-o no art. 2412 do Código Civil Italiano.
} 
aos títulos de crédito, que evitavam a alteração da estrutura acionária e, consequentemente, permitiam o financiamento da atividade sem a diluição do controlador.

Além das simples e conversíveis, tem-se no Brasil uma espécie herdada do direito inglês que é denominada "debêntures perpétuas", identificada pela ausência de termo final, em que o vencimento está sujeito a determinadas condições previstas no título (por exemplo, a inadimplência da obrigação de pagar juros e a dissolução da companhia), sendo ainda pouco utilizada pelos emissores.

Portanto, em relação às espécies, as debêntures são classificadas da seguinte forma: simples, perpétuas ou conversíveis em ações. ${ }^{173}$

Há certa confusão, todavia, com relação ao uso da terminologia espécies, já que a nomenclatura da Seção II, do Capítulo V, da LSA, que trata das debêntures, foi muito infeliz ao empregar a palavra espécie para se referir, na realidade, às modalidades de garantia. A LSA trata das espécies em seções esparsas. As conversíveis em ações estão disciplinadas no art. 57. Já as perpétuas, estão previstas no art. 55, §4º da LSA.

No tocante às garantias, a LSA disciplinou a temática em seu art. 58, da seguinte forma:

Art. 58. A debênture poderá, conforme dispuser a escritura de emissão, ter garantia real ou garantia flutuante, não gozar de preferência ou ser subordinada aos demais credores da companhia.

As debêntures, portanto, podem ser emitidas como títulos quirografários, sem qualquer tipo de garantia, colocando o debenturista na mesma posição que um simples credor.

Por outro lado, as debêntures também podem ser emitidas com garantia real, vinculando determinados bens da sociedade emitente, que devem ser identificados na escritura de emissão, para assegurar o cumprimento das obrigações contidas no título. Os bens

\footnotetext{
${ }^{173}$ Para o estudo aprofundado da disciplina das debêntures conversíveis em ações, ver a obra de Edmur de Andrade Nunes Pereira Neto, citada neste trabalho.
} 
dados em garantia não precisam ser necessariamente da companhia. Bens de terceiros podem garantir a emissão de debêntures.

Dentre as garantias reais, temos a hipoteca, o penhor e a alienação fiduciária. As duas primeiras estão disciplinadas no Código Civil e a última tem o seu regime previsto em lei especial (Lei n ${ }^{\circ}$ 9.514, de 20 de novembro de 1.997). No caso de alienação fiduciária, a escritura de emissão, lavrada com efeitos de escritura pública, serviria de documento hábil para fins de registro na matrícula do imóvel objeto da operação, nos termos do art. $38^{174}$ da referida lei. O agente fiduciário, por sua vez, funcionaria como representante legal da organização dos debenturistas para fins de representação perante o cartório de registro de imóveis, bem como para a custódia dos bens dados em garantia, já que a LSA estabelece que tal função pode ser atribuída ao agente na escritura de emissão (art. 69).

A garantia flutuante é outra modalidade que estabelece um privilégio geral sobre os credores quirografários da sociedade emitente. Não há vinculação de bem ou ativo específico. Há, apenas, uma preferência em caso de eventual falência ou recuperação do emitente. Assim como as hipotecas, a garantia flutuante é organizada pela ordem de inscrição da escritura de emissão, ou seja, há uma ordem de preferência entre as emissões. Não há tal preferência, todavia, dentro da mesma emissão, concorrendo as séries em igualdade.

Outra modalidade, muito comum à época em que a LSA limitava a emissão ao valor do capital social, é a subordinada aos demais credores. Neste caso, em que as debêntures não possuem garantias, os debenturistas teriam preferência apenas em relação aos acionistas em caso de falência da sociedade emitente. Os credores quirografários, por sua vez, teriam preferência sobre os titulares de debêntures subordinadas. O revogado $\S 4^{\circ}$ do art. 60 estabelecia que o limite de emissão não se aplicava às subordinadas. Muitas companhias fizeram uso dessa exceção para escapar da limitação da LSA. Atualmente, com a revogação integral do art. 60 e de todos os seus parágrafos, no âmbito da reforma introduzida pela Lei ${ }^{\circ}$ 12.4431/2011, acredita-se que o movimento de emissão de debêntures subordinadas seja refreado, tendo em vista que é modalidade com baixo nível de proteção aos debenturistas.

\footnotetext{
174 “Art. 38. Os atos e contratos referidos nesta Lei ou resultantes da sua aplicação, mesmo aqueles que visem à constituição, transferência, modificação ou renúncia de direitos reais sobre imóveis, poderão ser celebrados por escritura pública ou por instrumento particular com efeitos de escritura pública."
} 
Além das garantias previstas na LSA, a doutrina entende que outras modalidades poderão ser inseridas na escritura de emissão, tendo em vista o princípio da autonomia privada. Tavares Borba cita, como exemplo, a garantia fidejussória, por meio de fiança prestada pelos sócios controladores ou através de fiança bancária. Todavia, a bancária pode não ser interessante para a companhia, em razão do custo financeiro para a sua obtenção. $^{175}$

Com relação à natureza da garantia, Carvalhosa ensina que "consistem em direito acessório, subordinadas que estão ao direito de crédito do debenturista. Pressupõem a validade e eficácia do crédito, para o seu exercício, pois constituem garantia do pagamento de uma dívida”. Cita, ainda, o Parecer CVM n 6/79 para justificar que o perecimento ou a satisfação do direito principal enseja a insubsistência da garantia, ou seja, havendo a extinção das debêntures, liberam-se as garantias. ${ }^{176}$

\footnotetext{
${ }^{175}$ Ob. cit., pp. 80-81.
}

${ }^{176}$ Ob. cit., p. 783. 


\section{COMPARAÇÃO ENTRE AS DEBÊNTURES E OUTROS VALORES MOBILIÁRIOS DE DÍVIDA}

Além das debêntures, outros valores mobiliários de dívida são colocados à disposição da sociedade para a sua capitalização ou financiamento. As partes beneficiárias e as notas comerciais (commercial papers), por exemplo, são instrumentos alternativos às debêntures para fins de captação de recursos financeiros por meio de títulos de dívida, cada uma com suas características próprias e distintivas entre si, as quais serão analisadas a seguir.

Os bônus de subscrição são considerados valores mobiliários de participação no capital social e, portanto, não seriam assemelhados às debêntures, enquanto títulos de dívida, apesar de terem a mesma finalidade - instrumento de financiamento da sociedade. ${ }^{177}$ Por esta razão, não analisaremos comparativamente as debêntures em face dos bônus de subscrição.

\subsection{Partes beneficiárias}

As partes beneficiárias ${ }^{178 \_179}$ são títulos negociáveis que podem ser emitidos pela companhia a qualquer tempo para fins de capitalização, sendo emitidas sem valor nominal e na condição atribuída por lei de título "estranho ao capital social”, ou seja, apenas e

\footnotetext{
${ }^{177} \mathrm{O}$ único entrelaçamento entre as duas espécies de valores mobiliários aqui mencionadas, verifica-se na possibilidade de se atribuírem aos debenturistas, como vantagem adicional, os bônus de subscrição. Ou seja, a sociedade poderia emitir os bônus de subscrição não para alienação a terceiros, mas para atribuição aos titulares de debêntures já emitidas, nos termos do caput do art. 77 da LSA.

${ }^{178}$ Segundo Tavares Guerreiro e Egberto Lacerda (Ob. cit., p. 333), é um "instituto originário do direito francês (parts de fondateur)" que pode ser utilizado para as mais variadas finalidades "desde a pura e simples captação de recursos financeiros até a disciplina de interesses insuscetíveis de composição através de outros mecanismos societários.".

179 "A origem histórica das partes de fundador ou partes beneficiárias está vinculada à construção do Canal de Suez. Foram elas, com efeito, pela primeira vez imaginadas e criadas no século passado, com o lançamento da Companhia do Canal de Suez, por Ferdinand de Lesseps, que a fundou em 1856, destina a cortar aquele istmo e posteriormente explorar o empreendimento marítimo. Autorizada pelo Khediva do Egito, aquela companhia concedeu 100 títulos ao grupo de capitalistas que confiavam no êxito do empreendimento, atribuindo-lhes uma percentagem nos lucros, sem envolver o capital social.” (Rubens Requião, ob. cit., p. 312). Cf. também Ripert e Roblot, ob. cit., p. 561.
} 
tão somente como títulos de dívida, apesar de conferirem a seus titulares o direito de participação nos lucros anuais.

A LSA (art. $46, \S 1^{\circ}$ ) estabelece que os titulares das partes beneficiárias terão "direito de crédito eventual contra a companhia, consistente na participação nos lucros anuais".

A diferença, portanto, entre as partes beneficiárias e as debêntures, no que tange à contrapartida da companhia, é que as debêntures tem a certeza de seu pagamento, tanto do rendimento ao longo do tempo, como do principal em seu vencimento, conforme disposto na escritura de emissão. Já as partes beneficiárias estão sujeitas à verificação de lucro ao término do exercício social, após as deduções dos prejuízos acumulados, da provisão para o imposto de renda e das participações estatutárias dos empregados e administradores, e tem preferência sobre os dividendos, quando pagos à conta do lucro líquido do exercício. ${ }^{180}$

A doutrina denomina o direito de crédito das partes beneficiárias de "eventual" 181 , tendo em vista que, inexistindo lucro suficiente para suportar as deduções anteriormente mencionadas, o titular das partes beneficiárias não auferirá o rendimento de seu título.

Outra diferença relevante entre os valores mobiliários aqui tratados é a vedação expressa de emissão de partes beneficiárias por sociedades anônimas de capital aberto, restando apenas a sua emissão às sociedades de capital fechado, que não tenham registro na Comissão de Valores Mobiliários. Tal vedação foi inserida na LSA a partir da reforma promovida pela Lei $\mathrm{n}^{\circ} 10.303 / 2001$, posto que a redação anterior admitia a emissão a título oneroso ou para atribuição gratuita a sociedades ou fundações beneficentes de seus empregados. Já as debêntures não possuem tal vedação legal e, por outro lado, são frequentemente emitidas por companhias abertas.

Os institutos se assemelham, todavia, no que se refere à proibição de sua emissão pelas instituições financeiras, conforme disposto no art. 35, I, da Lei $\mathrm{n}^{\circ} 4.595$, de 31 de dezembro de 1964. Distinguem-se, por outro lado, com relação à ressalva que a

\footnotetext{
${ }^{180}$ Tavares Guerreiro e Egberto Lacerda, ob. cit., p. 334.

${ }^{181}$ Nelson Eizirik, ob. cit., pp. 322-323.
} 
mencionada lei faz no parágrafo único do mesmo art. 35, admitindo a emissão de debêntures por instituições financeiras que não recebam depósitos do público, porém condicionando-a à prévia autorização do Banco Central do Brasil.

Outra distinção entre os institutos é a limitação de participação das partes beneficiárias no lucro da companhia, resultando em limite ao proveito econômico a ser auferido pelos titulares de tal valor mobiliário. Aqui não se trata de limite à emissão, como se verificava no regime jurídico das debêntures antes da alteração promovida pela Lei $\mathrm{n}^{\circ}$ 12.431/2.011, mas de limite ao crédito conferido pelas partes beneficiárias aos seus titulares. Tal limite é de um décimo dos lucros ( $\$ 2^{\circ}$ do art. 46 da LSA). As debêntures, por outro lado, não possuem tal limitação expressa em lei.

Rubens Requião afirma que as partes beneficiárias se distinguem das ações e das debêntures porque não seriam representativas de um título patrimonial ou financeiro, sendo consideradas meramente "títulos concedidos pela sociedade sem outro conteúdo senão o crédito eventual de participação no lucro líquido ${ }^{182}$ da sociedade anônima."183

Por fim, outro traço distintivo é a vedação expressa de criação de mais de uma classe ou série de partes beneficiárias (art. 46, $\S 4^{\circ}$, da LSA), enquanto que a emissão de debêntures pode ser dividida em séries, nos termos do art. 53 da LSA.

\subsection{Notas comerciais}

As notas comerciais, ou commercial papers, são também consideradas valores mobiliários de dívida, nos termos do art. $2^{\circ}$, VI, da Lei $n^{\circ} 6.385 / 76$. Todavia, a emissão se dá para financiamento das operações de curto prazo das sociedades, em contraposição às debêntures que, usualmente, são emitidas com duração de médio e longo prazo.

\footnotetext{
${ }^{182}$ A nosso ver, com a devida vênia, a expressão lucro líquido não é a mais adequada, posto que a participação das partes beneficiárias é deduzida antes de se apurar o lucro líquido conceituado na LSA (art. 191). Poderíamos denominá-lo de lucro intermediário (art. 190 da LSA), pois ele está após as deduções dos prejuízos acumulados e da provisão de imposto de renda (art. 189 da LSA), mas antes do lucro líquido.

183 Ob. cit., p. 316.
} 
Para o direito norte-americano, as notas são consideradas valores mobiliários (securities), via de regra, por evidenciarem uma promessa de pagamento do devedor por um investimento realizado pelo credor. Todavia, certas características das notas podem excluí-las do conceito de valores mobiliários. Para o Securities Act de 1.933, as notas emitidas com vencimento em até nove meses de sua emissão estão dispensadas de registro. A doutrina reconhece que, neste caso, a exceção teve por objetivo atingir o commercial paper, que é definido como uma nota promissória sem garantia emitida por grandes companhias para financiar suas operações de curto prazo, sendo distribuídas para investidores institucionais ou qualificados. $^{184}$

A Suprema Corte dos Estados Unidos, ao julgar o caso Reves v. Ernst \& Young (494 U.S. 56, 1.990) ${ }^{185}$, adotou um teste conhecido como "family resemblance test" para solucionar a divergência entre várias Cortes com relação à definição das notas como valores mobiliários. O teste parte da premissa de que todas as notas são securities, a menos que esteja em uma das categorias de instrumentos que não são considerados valores mobiliários, trazendo como exemplos de notas que não são securities aquelas emitidas nos empréstimos aos consumidores e as que tenham como garantia uma hipoteca (mortgage on a home) ou a cessão de contas a receber.

O teste, ainda, apresenta quatro fatores para que uma nota seja considerada um valor mobiliário, quais sejam: (i) motivação do vendedor e do comprador - emissão para fins não específicos; (ii) plano de distribuição - distribuição e negociação por uma extensa base de investidores não institucionais ou não qualificados (notas distribuídas a um grupo limitado de investidores qualificados, em negociações diretas, não são consideradas valores mobiliários); (iii) expectativa razoável de investimento público - caracterizar investimento, similar a um contrato de investimento coletivo; (iv) outros fatores que reduzem o risco -

\footnotetext{
${ }^{184}$ Palmiter, ob. cit., p. 47.

${ }^{185} \mathrm{O}$ caso tratou da seguinte problemática: se as notas emitidas pela the Farmer's Cooperative of Arkansas and Oklahoma seriam definidas como securities nos termos da definição apresentada pela Seção 3(a)10 do Securities Exchange Act de 1934. Após a Cooperativa requerer a autofalência, os titulares das notas ingressaram com a ação em face da Ernst \& Young sob a alegação de que a firma de auditoria supostamente não teria observado os princípios gerais de contabilidade em sua avaliação sobre um dos mais relevantes ativos da sociedade, violando as regras antifraude do Securities Exchange Act de 1934. A firma de auditoria recorreu sob a alegação de que as notas não seriam valores mobiliários e, por tal razão, não seriam aplicáveis as regras daquele ato normativo de 1934, levando o caso a julgamento pela Suprema Corte dos Estados Unidos, tendo como relator o Justice Marshall.
} 
possuir garantias e estar sujeita à regulação de autoridades financeiras podem diminuir o risco e levar a nota a não ser caracterizada como valor mobiliário. ${ }^{186}$

As notas são instrumentos flexíveis que admitem diversas configurações pelo emitente. É por isso que demandam a análise das características extrínsecas ao título para que sejam ou não conceituadas como valores mobiliários. Já as debêntures independem dos fatores externos (motivação, plano de distribuição, etc.) para serem caracterizadas como valores mobiliários.

No Brasil, além da inclusão das notas no rol dos valores mobiliário pela lei que instituiu o mercado, o Conselho Monetário Nacional (“CMN”) expediu a Resolução no 1.723 , de 27 de junho de 1.990, por meio da qual estabelece em seu primeiro artigo: "Considerar como valor mobiliário, para os efeitos da Lei $n^{\circ}$ 6.385, de 07.12.76, a nota promissória emitida por sociedade por ações, destinada à oferta pública."

Apesar da estranheza da definição, já que a mesma consta em lei anterior à Resolução, nota-se que o ato normativo do CMN, a partir da leitura de seu art. $2^{\circ}$, teve o intuito de excluir da definição de valor mobiliário as notas emitidas por instituições financeiras, nos moldes do que ocorreu nos Estados Unidos após a decisão do caso Reves.

Vejamos o que diz o artigo $2^{\circ}$ da Resolução 1.723: " $O$ disposto no artigo anterior não se aplica aos títulos emitidos por instituições financeiras, sociedades corretoras e distribuidoras de valores mobiliários e sociedades de arrendamento mercantil."

Aí está a razão da edição da referida Resolução. O artigo $1^{\circ}$ foi a cortina de fumaça necessária para retirar as notas promissórias emitidas por instituições financeiras e demais sociedades correlatas da definição de valores mobiliários e, por consequência, do âmbito de fiscalização da Comissão de Valores Mobiliários. Todavia, parece-nos que o ato normativo do $\mathrm{CMN}$ não poderia alterar a lei, retirando as notas emitidas por instituições financeiras de seu alcance.

${ }^{186}$ Palmiter, ob. cit., pp. 47-48. 
As notas comerciais (commercial papers) apresentam algumas características comuns às debêntures, pois (i) dependem da qualidade do emissor e de seu rating junto às agências de avaliação de risco; (ii) são títulos sem garantias reais ou fidejussórias; (iii) exigem registro na CVM, para distribuição pública. ${ }^{187}$

Por outro lado, as diferenças entre as debêntures subordinadas e as notas promissórias comerciais são as seguintes: (i) as notas são de prazo curtíssimo, enquanto as debêntures subordinadas, normalmente, são de prazo médio e longo ${ }^{188}$; (ii) as notas devem observar o valor mínimo de emissão ${ }^{189}$, enquanto as debêntures não estão sujeitas a um valor nominal unitário mínimo para a sua colocação no mercado; (iii) as notas serão consideradas créditos quirografários em caso de falência da sociedade emissora; já as debêntures subordinadas estão abaixo dos credores quirografários e têm preferência apenas sobre os acionistas em relação ao saldo remanescente dos ativos. ${ }^{190}$ e 191

\footnotetext{
187 SANTOS, Theophilo de Azeredo. Commercial Paper, Export Notes - Endossador Não-Responsável pelo Título de Crédito. Disponível em: http://daleth.cjf.jus.br/revista/seriecadernos/VOL16-7.htm. Acesso em: $18 / 04 / 2013$.

188 "Nos Estados Unidos, em 1997, a empresa Safra Republic Holding S.A. emitiu, em base fiduciária pelo Republic Bank of New York, em Luxemburgo, para financiar e manter empréstimo por debêntures subordinadas com vencimento em 15 de outubro de 2.997, vale dizer, título de 1.000 anos. Entre nós, o prazo médio do Commercial Paper está em 180 dias, ao passo que as debêntures têm sido lançadas com vencimento de 3 a 5 anos, a fim de melhor atender ao planejamento financeiro das empresas." (Azeredo Santos, ob. cit., s/n)

${ }^{189} \mathrm{O}$ art. $2^{\circ}$ da Instrução CVM n ${ }^{\circ} 155$, de 7 de agosto de 1.991, define as condições para emissão de notas pelas sociedades, dentre elas o valor nominal unitário mínimo: "I - ter por objeto notas promissórias cujo valor nominal unitário seja, no mínimo, de R \$500.000,00 (quinhentos mil reais);” e

${ }^{190} \mathrm{O}$ art. 83 da Lei ${ }^{\circ}{ }^{11.101 / 2.005}$ estabelece a ordem de classificação dos créditos em caso de falência da sociedade emissora.

${ }^{191}$ SANTOS, Theophilo de Azeredo. Commercial Paper, Export Notes - Endossador Não-Responsável pelo Título de Crédito. Disponível em: http://daleth.cjf.jus.br/revista/seriecadernos/VOL16-7.htm. Acesso em: $18 / 04 / 2013$.
} 


\section{FUNÇÃO DAS DEBÊNTURES}

As debêntures se prestam a diversos negócios jurídicos que visam capitalizar a sociedade. ${ }^{192}$ Como dito anteriormente, enquanto instituto de direito societário, revelam-se valores mobiliários de dívida, emitidos em série, que tem por função permitir às sociedades a obtenção de recursos junto ao público investidor para o desenvolvimento de suas atividades, com a dispersão dos credores.

Essa é, inclusive, a função essencial das debêntures, como nos mostra a unanimidade da doutrina. ${ }^{193}$ Tão essencial para o funcionamento da sociedade e o exercício da empresa que, em alguns países, como nos Estados Unidos, a emissão de bonds e debentures é admitida até mesmo sem a necessidade de expressa autorização no ato constitutivo da sociedade. $^{194}$

Waldecy Lucena ensina que a emissão de debêntures é uma das vias clássicas de busca de capitais, "tido em geral como um instrumento eficaz de captação, distribuído, como modalidade de valor mobiliário, no mercado de capitais", arrematando que as debêntures, por serem títulos abstratos, podem ter como causa "vários negócios jurídicos subjacentes, como sejam novação, transação, dação em pagamento, servindo para pagamento tanto de obrigações sociais anteriormente contraídas, como de obras e serviços de interesse da

\footnotetext{
${ }^{192}$ Para Carvalhosa (Ob. cit., p. 662), “a função das debêntures é a de capitalizar a sociedade. São, desse modo, títulos de crédito representativos da totalidade do débito contraído pela companhia, consoante escritura de emissão aprovada pela assembleia geral". O único equívoco, a nosso ver, nesse trecho extraído da obra de Carvalhosa, é a categorização das debêntures como títulos de crédito, como discorrido anteriormente ao tratarmos de seu conceito e natureza jurídica. Trata-se na verdade de instituto que se encaixa na categoria autônoma dos valores mobiliários.

193 Já para Nelson Eizirik (Ob. cit., p. 319), “a finalidade econômica da debênture consiste em possibilitar o financiamento da companhia emissora, mediante empréstimo contraído junto a restrito círculo de pessoas (quando se trata de emissão privada) ou mediante apelo à poupança popular (no caso de emissão publica colocada no mercado de capitais)." A nosso ver, o mais adequado seria utilizar a palavra "função" ao invés de "finalidade". As debêntures têm função econômica, posto que utilizadas primordialmente para o financiamento da sociedade. Porém, a finalidade da emissão pode ser das mais diversas, e não necessariamente sempre econômica. Como exemplo, temos a emissão de debêntures conversíveis no âmbito de uma reorganização societária ou aquisição de participação societária, por meio de negócio jurídico indireto, já que nessa hipótese a emissão tem uma finalidade imediata que é jurídico-societária, e não econômica, cujo objetivo é permitir que os titulares das debêntures conversíveis detenham, ao final da operação, participação acionária que cause a diluição da base acionária anterior à conversão.

194 "The power to issue bonds and obligations is not dependente, as are stock issues, upon express authorization in the articles of incorporation" (BALLANTINE, Henry Winthrop. Ballantine on Corporations. Chicago: Callaghan, 1946, p. 494). No mesmo sentido, Cox e Hazen, ob. cit., p. 516.
} 
sociedade, em cujas operações pode inclusive ocorrer, o que não é incomum, o não ingresso de recursos financeiros para o caixa da companhia."

De fato, a causa para o lançamento de debêntures pode ser das mais variadas. Nem por isso, mesmo não havendo ingresso de dinheiro no caixa da companhia, elas deixam de ter a sua função econômica, que sempre subsistirá. O uso das debêntures como meio de pagamento para outras obrigações contraídas anteriormente à sua emissão não descaracteriza a sua função econômica.

É a própria sociedade que dá início à marcha de financiamento por meio das debêntures. A sociedade cria, emite e coloca o valor mobiliário em circulação. No caso de uso das debêntures para pagamento de obrigações já contraídas, em que o valor mobiliário serve de papel moeda para quitação de uma dívida preexistente, ou para garantia de operação já contratada, tem-se aí uma operação de financiamento que se opera por meio de substituição de passivos. Por exemplo, a sociedade tem uma dívida contabilizada com o prestador de serviços "A" (credor) no valor de um milhão de reais. Ao invés de dispor de seu caixa, a sociedade resolve emitir debêntures que são entregues ao referido credor, substituindo a dívida pelo valor mobiliário lançado no passivo. O fornecedor, por sua vez, poderá alienar o valor mobiliário e receber dinheiro do adquirente, que assumirá a posição de debenturista, ou pode oferecer o título em garantia de uma operação financeira, aguardando o vencimento da debênture para sua liquidação. 


\section{CRIAÇÃo, EMISSÃO, COLOCAÇÃO E CIRCULAÇÃO: CONCEITOS E IMPLICAÇÕES LEGAIS}

O tema deste capítulo se deve à necessidade de se estabelecer precisamente a definição e as implicações legais dos termos utilizados para representar as etapas de surgimento, existência e de movimento em direção ao mercado das debêntures. "São fases do iter procedimental por que passam as debêntures"195. A delimitação precisa de cada etapa tem suas consequências jurídicas para os sujeitos que participam da relação debenturística. Abordaremos os temas em dois grupos. O primeiro, que trata do momento inicial de surgimento do título, analisará a criação e a emissão das debêntures. Já o segundo grupo, que representa o momento posterior à emissão, tratará da colocação e circulação dos referidos valores mobiliários, cujo movimento projeta o título para fora da sociedade, lançando-o nas mãos de terceiros que o subscrevem, dando vida autônoma às debêntures e imputando ao subscritor a posição de debenturista.

Iniciaremos a análise das definições acerca da criação e emissão das debêntures e, na sequência, abordaremos a colocação e a circulação do título.

\subsection{Criação e emissão}

Tavares Guerreiro e Egberto Teixeira, sempre inovadores, foram os primeiros a discorrer sobre a necessária distinção entre criação e emissão das debêntures. Apesar de pouco abordado pelo restante da doutrina, o tema é dos mais pertinentes para a evolução prática das debêntures e, por essa razão, merece ser renovado neste trabalho. ${ }^{196}$

Nesse sentido, vale a pena transcrever os ensinamentos dos referidos juristas a respeito da distinção ora em exame:

\footnotetext{
195 LUCENA, José Waldecy. Das Sociedades Anônimas. Comentários à Lei. Vol. 1. Rio de Janeiro: Ed. Renovar, 2009, p. 624.

${ }^{196}$ Ob. cit., p. 358.
} 


\begin{abstract}
"Cremos ser necessário distinguir entre criação e emissão de debêntures. Muito embora, na rubrica da Seção III do Capítulo V, a Lei n ${ }^{0} 6.404$ admita a identidade de um e outro instituto, nos dispositivos pertinentes não se encontra qualquer conceituação específica a respeito, que deve, portanto, ser extraída mediante interpretaçõa sistemática do texto legal. Sendo certo que a previsão estatutária não é condição suficiente para o nascimento das debêntures, parece-nos que a criação delas resulta da deliberação da Assembleia Geral que torna efetiva a intenção da companhia de proceder a essa modalidade de operação de crédito, discriminando suas características, nos termos do art. 59. A emissão das debêntures, porém, é ato subsequente à deliberação assemblear, materializado pela escritura de emissão, a que se refere o art. 61, e uma vez satisfeitos os requisitos previstos no art. 62, com a consequente instrumentação da dívida debenturística através dos certificados, que devem obedecer as prescrições formais do art. 64."197
\end{abstract}

Como visto acima, tem-se à primeira vista a falsa sensação de que o legislador pretendeu usar os termos criação e emissão como sinônimos. Essa impressão equivocada decorre da infeliz nomenclatura utilizada na Seção III, do Capítulo V, da LSA. Todavia, uma análise mais acurada dos arts. 59 a 62 nos mostra que criação e emissão são negócios jurídicos distintos, porém complementares.

A criação é negócio jurídico societário de competência privativa da assembleia geral, salvo nas companhias abertas em que o conselho de administração poderá deliberar sobre a criação de debêntures não conversíveis em ações. ${ }^{198}$ Criação não se confunde com emissão. A criação é o ato precedente que disciplina a emissão. O caput do art. 59 é que dá margem a essa confusão, ao referir que a assembleia deverá deliberar sobre a "emissão de debêntures". Trata-se de impropriedade do texto, a nosso ver. Na verdade, a deliberação da assembleia é de criação das debêntures e de aprovação das condições de emissão do título. É um projeto de emissão. Não é a própria emissão. Esta ocorrerá, como veremos a seguir, a partir da lavratura da escritura e do cumprimento de certos requisitos para sua regularidade.

Carvalhosa, nesse mesmo sentido, afirma que a criação e a emissão de debêntures não se confundem, sendo que "a primeira é consequente à deliberação da assembleia geral ou do conselho de administração ( $\left(1^{\circ}\right.$ deste art. 59). Já a emissão somente se configura em momento posterior, com a cabal formalização da escritura respectiva."199

\footnotetext{
${ }^{197}$ Ob. cit., p. 358.

198 A doutrina construída no regime anterior à LSA era pacífica no sentido de que a disposição estatutária que atribuisse competência a outro órgão da companhia, retirando a competência privativa da assembleia, seria inválida.

199 Ob. cit., p. 810.
} 
Para corroborar esse entendimento, devemo-nos atentar para a redação do $\S 4^{\circ}$ do art. 59 da LSA, onde se lê que a assembleia pode delegar ao conselho a deliberação "sobre as condições de que tratam os incisos VI a VIII do caput e sobre a oportunidade da emissão". Está mais do que claro aqui que a deliberação da assembleia é de criação, e não de emissão. Se não fosse assim, não faria sentido transferir por delegação a deliberação sobre a oportunidade da emissão ao conselho.

Tal distinção é importante pois, como ensina a doutrina, "a existência legal das debêntures depende da assinatura da escritura de emissão" ${ }^{200}$. Isto é, a deliberação de criação, por si só, não caracteriza a emissão das debêntures, sendo ela dependente da lavratura da escritura de emissão para ter vida e existir juridicamente. ${ }^{201}$

Dessa forma, a emissão das debêntures será levada a cabo pela companhia por meio da lavratura da escritura prevista no art. 61 da LSA, que deverá conter os direitos conferidos aos debenturistas, suas garantias e demais cláusulas ou condições. Mais um motivo para nos levar à opinião de que a deliberação da assembleia é de criação das debêntures, já que a escritura de emissão deverá conter uma série de disposições que não são obrigatórias e podem não estar mencionadas na deliberação de criação. Portanto, a emissão decorre do ato de criação das debêntures. Sem a criação, inexiste a possibilidade de lavratura da escritura de emissão.

Carvalhosa explica, com a clareza que lhe é peculiar, a fase de emissão das debêntures, da seguinte forma:

"Já a emissão corresponde à fase em que as debêntures, criadas de acordo com a lei,
os regulamentos administrativos e o estatuto, estão aptas a ser ofertadas aos
tomadores do mercado de capitais (emissão pública) ou desde logo colocadas junto
aos investidores institucionais ou junto aos próprios acionistas (emissão privada)."202

Divide-se a fase de emissão, por seu turno, em dois procedimentos distintos: o primeiro é o de elaboração e assinatura da escritura de emissão (existência legal do instrumento de criação das debêntures); e o segundo é o registrário, que visa dar cumprimento

\footnotetext{
${ }^{200}$ Tavares Borba, ob. cit., p. 99.

${ }^{201}$ Tavares Borba (Ob. cit., p. 99) ensina, ainda, que "a escritura de emissão, que poderá ser celebrada por instrumento público ou particular, é que dá vida às debêntures, criando-as e inserindo-as no mundo do direito." ${ }^{202}$ Ob. cit., p. 811.
} 
aos requisitos previstos no art. 62 da LSA e tem por objetivo produzir efeitos perante terceiros (potenciais subscritores do valor mobiliário, credores, etc.).

A feitura da escritura de emissão deve observar o disposto no artigo 61 da LSA, que estabelece: "a companhia fará constar da escritura de emissão os direitos conferidos pelas debêntures, suas garantias e demais cláusulas ou condições”.

Importante destacar, neste ponto, a possibilidade de emissão de debêntures no modelo completo e a emissão de debêntures padronizadas, que se valem de cláusulas ou condições padrões que devem ser inseridas nas escrituras de emissão e que permitem, a partir da padronização da escritura, a sua negociação em segmento especial da Bolsa de Valores ou do mercado de balcão. ${ }^{203}$

Não se deve falar em formalização do empréstimo debenturístico. Este não ocorre apenas com a lavratura da escritura de emissão. A doutrina predominante entende que a formalização ocorre a partir da subscrição do título e do pagamento à companhia do valor nele expresso. ${ }^{204}$

De acordo com Carvalhosa, ainda, "a subscrição significa o ato negocial de firmar o empréstimo pelos meios usuais do mercado, e que corresponde, para todos os efeitos jurídicos, à aceitação da oferta promovida com tal finalidade."205

Como veremos mais adiante, a fase posterior à emissão é a de colocação das debêntures, em que se verifica a subscrição e a integralização das mesmas, configurando-se aí a formalização do empréstimo debenturístico.

\footnotetext{
${ }^{203}$ A esse respeito, a Instrução CVM n n $^{\circ} 404$, de 13 de fevereiro de 2004, dispõe sobre o procedimento simplificado de registro e padrões de cláusulas e condições que devem ser adotados nas escrituras de emissão de debêntures destinadas a negociação em segmento especial de bolsas de valores ou entidades do mercado de balcão organizado.

${ }^{204}$ Tavares Guerreiro e Egberto Teixeira (Ob. cit., p. 362) comentam que "a escritura de emissão não se reveste do caráter de instrumento contratual, a refletir a bilateralidade inerente ao mútuo [eles são defensores dessa teoria], mas, ao contrário, exprimirá uma declaração unilateral de vontade, por parte da companhia emissora, contendo as cláusulas, garantias e condições oferecidas aos tomardores das debêntures. Temos para nós que a formalização do empréstimo mediante debêntures se concretiza com a efetiva prestação de numerário pelos debenturistas, que aderem às disposições da escritura. Daí entendermos acertada a lição de WALDEMAR FERREIRA, segundo a qual o contrato de empréstimo mediante debêntures (que sucede, no tempo, à celebração da escritura) outro não é senão o chamado contrato de adesão."

${ }^{205}$ Ob. cit., p. 811.
} 
Com isso, podemos delimitar a fase de emissão como sendo aquela que se inicia com a elaboração da escritura, passando por sua assinatura, e se encerra com a conclusão dos atos registrários previstos no artigo 62 da LSA.

A escritura de emissão foi introduzida no direito brasileiro a partir da Lei ${ }^{0}$ 6.404/76. Anteriormente, adotava-se a figura do manifesto. Inovou-se acertadamente, reconhecendo a doutrina suas vantagens para a emissão das debêntures. Superou-se, também, a dúvida sobre a sua natureza jurídica que, hoje, está pacificada no sentido de ser ela uma declaração unilateral de vontade. Esta também é a qualificação jurídica adotada pela CVM, conforme Parecer CVM/SJU/N. 037, de 13 de maio de 1983, como bem anotou Waldecy Lucena $^{206}$.

Leães observa que a escritura de emissão se inspirou no trust indenture ou deed of trust, proveniente do direito inglês e norte-americano, "que é um contrato formal celebrado entre a sociedade e o agente fiduciário como representante dos debenturistas" ${ }^{207}$. No Brasil, por sua vez, exige-se a participação do agente fiduciário na escritura de emissão apenas para a colocação pública dos títulos, nos termos do parágrafo $1^{\circ}$ do artigo 61 da LSA. Sendo as debêntures emitidas para colocação privada, a escritura contará apenas com a firma dos administradores da sociedade emissora.

Além dos requisitos obrigatórios previstos nos incisos do art. 59 da LSA, que foram objeto de deliberação pela assembleia ou conselho, a escritura de emissão deve conter os direitos conferidos aos debenturistas, as garantias e demais cláusulas ou condições. Interessante destacar ainda, neste ponto, que caberá à administração da companhia elaborar a escritura de emissão, fazendo constar as matérias fixadas pela assembleia ou conselho (art. 59), complementando-as, naquilo que lhe couber, para determinar, por exemplo, os critérios para escolha, nomeação e substituição do agente fiduciário, seus deveres e atribuições, além daqueles fixados em lei, "as regras sobre a convocação e deliberação das assembleias de debenturistas, bem como todas as demais obrigações a que a companhia emissora estará sujeita". 208

\footnotetext{
${ }^{206}$ Ob. cit., pp. 644-645.

${ }^{207}$ LEÃES, Luiz Gastão Paes de Barros. Comentários à Lei das Sociedades Anônimas. Vol. 2. São Paulo: Saraiva, 1980, pp. 54-55.

${ }^{208}$ Nelson Eizirik, ob. cit., pp. 387-388.
} 
A LSA não é clara a respeito do órgão da administração incumbido de elaborar e firmar a escritura de emissão. O caput do art. 61 refere-se à companhia. Todavia, por meio de interpretação lógico-sistemática, podemos concluir que a escritura deve ser assinada por um de seus diretores, nos termos do estatuto ou, sendo este silente, da deliberação colegiada que autorizar a sua emissão. Extrai-se este entendimento do art. 144 da LSA, que disciplina a "presentação" (e não a representação, como já alertava Pontes de Miranda) da companhia, ao estabelecer que "no silêncio do estatuto e inexistindo deliberação do Conselho de Administração (art. 142, II e parágrafo único), competirão a qualquer diretor a representação da companhia e a prática dos atos necessários ao seu funcionamento regular”. Parece-nos razoável, também, que a escritura deva ser elaborada pela diretoria e aprovada pelo conselho de administração. Silente o estatuto a esse respeito, aplica-se a regra geral contida no artigo 144 da LSA, competindo a qualquer diretor da sociedade a prática dos atos necessários à elaboração e lavratura da escritura de emissão.

Superada a fase de elaboração e assinatura da escritura de emissão, passa-se à etapa de registro e publicidade, prevista no artigo 62 da LSA, que exige as seguintes providências:

(i) arquivamento da ata da assembleia geral, ou do conselho de administração, que deliberou sobre a emissão no registro do comércio (leia-se, na Junta Comercial do Estado onde se localiza a sede da sociedade);

(ii) publicação da ata referida no item anterior nos jornais utilizados pela sociedade para as publicações legais;

(iii) inscrição da escritura de emissão no registro do comércio (leia-se, na Junta Comercial do Estado onde se localiza a sede da sociedade); e

(iv) constituição das garantias reais, se for o caso, com a inscrição da escritura de emissão no cartório de registro de imóveis, por exemplo. 
A redação original do art. 62 exigia a inscrição obrigatória de toda e qualquer escritura de emissão de debêntures no Registro de Imóveis. A Lei n ${ }^{0}$ 10.303/2.001, acertadamente, modificou a redação do inciso II do referido artigo e passou a exigir a inscrição no Registro de Imóveis apenas quando houver a constituição de garantia real ou quando constar na escritura cláusula de inalienabilidade ou de não oneração de bem imóvel. ${ }^{209}$

Nelson Eizirik explica que o fundamento da obrigatoriedade de registro público da escritura de emissão das debêntures se deve à "necessidade de se conferir autenticidade, segurança e eficácia" ${ }^{210}$, bem como para que terceiros que se relacionem com a sociedade emissora tenham conhecimento da existência do empréstimo debenturístico.

A distinção feita anteriormente, entre as etapas de criação e emissão das debêntures, dentre outras coisas, é de suma importância para se definir o regime da invalidade e da ineficácia dos atos praticados pelos órgãos da companhia ou por seus administradores.

Carvalhosa leciona que "a eficácia da deliberação assemblear ou do conselho de administração será apenas interna enquanto não cumpridos os requisitos de publicidade, os registrários e os autorizativos (art. 62) "211. O referido mestre afirma, ainda, que a validade e eficácia da deliberação que cria as debêntures está sujeita à observância das disposições legais e estatutárias. E qual a consequência do não cumprimento dos requisitos legais ou estatutários para emissão das debêntures?

Neste ponto, é interessante destacar que, no regime jurídico anterior do Decreto $\mathrm{n}^{\circ}$ 177-A, havia previsão expressa de nulidade da emissão - o que não ocorre atualmente na LSA -, em diversos ponto da norma, conforme a seguir reproduzido: (i) no tocante a inexistência de deliberação assemblear e ausência de aprovação das condições mínimas obrigatórias, o $\S 7^{\circ}$ do art. $1^{\circ}$ assim estabelecia: “A inobservância de qualquer destes preceitos $\left(\S \S 5^{\circ}\right.$ e $6^{\circ}$ ) envolve nulidade, em proveito dos obrigacionistas."; (ii) em razão da inobservância dos requisitos e das formalidades legais para emissão, o $\S 5^{\circ}$ do art. $2^{\circ}$ dispunha que "em caso de inobservância das formalidades estatuídas neste artigo até o $\S 3^{\circ}$,

\footnotetext{
${ }^{209}$ Nelson Eizirik, ob. cit., pp. 392-393.

${ }^{210}$ Ob. cit., p. 393.

211 Ob. cit., p. 804.
} 
inclusivamente, o tribunal poderá, conforme as circunstâncias, pronunciar a nulidade da emissão em benefício dos obrigacionistas.",212

A LSA nesse ponto foi silente, prevendo apenas o prazo prescricional para a ação dos debenturistas em face do agente fiduciário, por atos culposos ou dolosos, no caso de violação da lei ou da escritura de emissão (art. 287, II, “e”).

Todavia, o vetusto Decreto ${ }^{\circ}$ 177-A pode auxiliar no sentido de revelar como deve ser a abordagem em matéria de invalidades no tocante às debêntures. Deve-se separar a análise em dois momentos distintos: o da deliberação colegiada de criação das debêntures e o da lavratura da escritura de emissão.

Em se tratando do ato de criação das debêntures, que decorre de deliberação colegiada (ou da assembleia, ou do conselho), parece-nos razoável se aplicar o regime das invalidades das assembleias de sociedades anônimas, profundamente analisado por Erasmo Valladão Azevedo e Novaes França ${ }^{213}$, quando estivermos diante de vícios da assembleia, das deliberações ou do voto.

Todavia, a aplicação supletiva desse regime de invalidades deve valer tãosomente no âmbito de eficácia interna da sociedade emissora, entre os sócios e a sociedade e entre esta e os seus administradores, não podendo afetar os debenturistas que, de boa-fé, adquiriram os títulos.

Waldemar Ferreira defende que a nulidade somente pode ser decretada em benefício dos debenturistas, sendo, desse modo, "sempre válidas as debênturas e eficaz o empréstimo" 214 em relação aos titulares das debêntures. A sociedade não pode alegá-la em seu proveito, já que é ilícito se aproveitar de sua própria culpa.

Diferentemente, se houve completa inobservância das prescrições legais, inexiste empréstimo e, muito menos, debêntures. Logo, os subscritores ou adquirentes devem adotar todas as cautelas necessárias para se assegurarem da existência legal do título.

\footnotetext{
${ }^{212}$ Waldemar Ferreira (Ob. cit., p. 230) ensina que a inobservância de quaisquer prescrições legais "envolve a nulidade do empréstimo e, consequentemente, da emissão das debênturas."

${ }^{213}$ Cf. Invalidade das Deliberações de Assembleia das S.A. São Paulo: Malheiros, 1999.

${ }^{214}$ Instituições de Direito Comercial. Vol. 3. Tomo I. São Paulo: Max Limonad, 1958, p. 347.
} 
Waldemar Ferreira alerta: "não sejam negligentes no verificar se o empréstimo legalmente se lançou e os títulos legalmente se emitiram ou se somente se praticaram irregularidades que sejam saneáveis." 215

Já com relação ao tratamento dos vícios ou irregularidades verificadas na elaboração e lavratura da escritura de emissão, ou nos registros posteriores exigidos em lei, parece-nos que a abordagem deva ser feita casuísticamente, conforme veremos a seguir.

No tocante à conformação da escritura de emissão, os vícios podem ser de duas ordens: vícios sanáveis ou insanáveis. No primeiro caso, estamos diante das hipóteses de anulabilidade ou nulidade relativa, em que o ato anulável produz seus efeitos até a sentença que a decreta, podendo ser ratificado. ${ }^{216}$ Por exemplo, o estatuto social de uma determinada companhia dispõe que o conselho de administração tem que autorizar a diretoria a assinar a escritura de emissão, especificando os diretores que deverão fazê-lo. Imagine que tal deliberação não tenha sido tomada e a escritura tenha sido assinada mesmo assim. Trata-se de anulabilidade, uma vez que a companhia poderá sanar o vício mediante ratificação pelo conselho de administração. É o que diz o art. 176 do CC: "quando a anulabilidade do ato resultar da falta de autorização de terceiro, será validado se este a der posteriormente.”

Os vícios que decorrem da ausência de elementos substanciais ou essenciais do negócio, por sua vez, não produzem efeitos e não são passíveis de convalidação. Temos como exemplo a ausência da data de vencimento na escritura de emissão da debênture ${ }^{217}$ - salvo nas debêntures perpétuas ou permanentes (art. $55, \S 4^{\circ}$, da LSA) -, o que impede a sua liquidação e, consequentemente, prejudica o direito essencial do debenturista de receber a restituição do capital entregue à companhia. Neste caso, sendo o negócio declarado nulo, a companhia terá que restituir o valor subscrito devidamente corrigido e, ainda, estará sujeita ao ressarcimento de eventuais perdas e danos sofridos pelos debenturistas, podendo, em regresso, acionar os administradores que deram causa à emissão.

Por outro lado, se a irregularidade estiver relacionada à ausência de providências de registro ou publicidade, a própria LSA resolve o problema ao admitir que o

\footnotetext{
${ }^{215}$ Ob. cit., p. 347.

${ }^{216}$ O Código Civil trata das hipóteses de anulabilidade do negócio jurídico a partir do art. 171.

${ }^{217}$ Conforme exigido pelo caput do art. 55 da LSA.
} 
agente fiduciário ou qualquer debenturista possa "promover os registros requeridos neste artigo e sanar as lacunas e irregularidades proventura existentes nos registros promovidos pelos administradores da companhia" (art. 62, § $2^{\circ}$, da LSA). Portanto, a ausência dos registros requeridos pelo art. 62 não levam à nulidade ou anulabilidade, mas apenas à ineficácia. Respondem os administradores pelas perdas e danos causados à companhia ou a terceiros em razão da ausência do registro, inscrição ou publicação.

Como a escritura é elaborada, lavrada e levada a registro pela administração da companhia, com anuência do agente fiduciário, quando for o caso, pode-se concluir que os vícios existentes no texto da carta de emissão e as responsabilidades deles decorrentes devam ser imputados àqueles que a elaboraram, mediante responsabilização dos administradores e do agente fiduciário, aplicando-se, respectivamente, a disciplina contida nos arts. 158 e 159 e no art. $68, \S 4^{\circ}$, todos da LSA. ${ }^{218}$

E ainda, especificamente no tocante às cláusulas da escritura que restrinjam os deveres, atribuições e responsabilidade do agente fiduciário, previstos no art. 68 da LSA, a própria lei traz a solução para o problema, reputando-as não escritas.

\subsection{Colocação e circulação}

Colocação e circulação se revelam, também, etapas marcantes do iter procedimental das debêntures.

Carvalhosa, ao citar De Chiara, ensina que "colocação, para os efeitos do $\S 3^{\circ}$ da norma ora em estudo, significa ingresso dos recursos do mútuo no caixa da companhia

\footnotetext{
${ }^{218}$ Interessante notar que a ação de responsabilidade do administrador será promovida pela companhia se os prejuízos forem causados ao seu patrimônio. Caso os prejuízos tenham sido causados apenas aos debenturistas, parece-nos lógico que a ação cabível é aquela prevista no $\$ 7^{\circ}$ do art. 159 da LSA, ou seja, os debenturistas terão ação direta em face do administrador que praticou o ato com culpa ou dolo, violando a lei, o estatuto ou a deliberação colegiada de criação das debêntures. A ação cabe aos debenturistas que, em comunhão, serão representados pelo agente fiduciário, nos termos do $\$ 3^{\circ}$ do art. 68 da LSA. Caberá ação de responsabilidade também em face do agente fiduciário, pois é ele o responsável por verificar a legalidade da escritura de emissão antes de sua aceitação e nomeação, respondendo perante os debenturistas pelos prejuízos causados em razão de sua conduta culposa, nos termos do art. $68, \S 4^{\circ}$, da LSA.
} 
emissora" ${ }^{219}$, delimitando a etapa ou fase de colocação entre a data de início da oferta do título até o término da subscrição primária, com o ingresso de recursos no caixa da sociedade emissora. $^{220}$

Pinheiro Guimarães, em obra coordenada pelos autores da LSA, leciona o seguinte:

\begin{abstract}
"Subscrição é o ato de aquisição das debêntures, formalizado por meio da assinatura do respectivo boletim de subscrição. A subscrição pode ser feita para pagamento do preço de subscrição à vista ou a prazo. O pagamento do preço de subscrição é denominado integralização. Na subscrição para integralização à vista o preço de subscrição é pago no ato da subscrição, enquanto na subscrição para pagamento a prazo o preço de subscrição é pago de acordo com o que estiver estipulado na escritura de emissão e no boletim de subscrição.",221
\end{abstract}

Parece-nos que a colocação estará perfeita e acabada com a integralização das debêntures, ou seja, com a entrada efetiva no caixa da companhia do valor nominal dos títulos subscritos, que é de fácil verificação na colocação de debêntures cujo pagamento ocorre à vista. E no caso de integralização parcelada? Carvalhosa esclarece que, enquanto não forem totalmente integralizadas, as debêntures devem ficar indisponíveis, "evitando assim uma circulação que, embora nominativa, criaria enorme confusão quanto ao pagamento dos benefícios atribuídos aos títulos debenturísticos da respectiva série”222. Essa indisponibilidade, ainda que temporária, seria assegurada pelas entidades que prestam os serviços de registro, custódia, negociação e liquidação de ativos e títulos (p.ex., CETIP ou BMF\&Bovespa - Bovespa Fix), que serão tratadas mais adiante nesta dissertação.

Todavia, tal entendimento não se aplicaria à integralização em bens, cuja verificação dependeria da avaliação, nos termos do art. $8^{\circ}$ da LSA, bem como da efetiva

\footnotetext{
${ }^{219}$ Ob. cit., p. 812.

220 "A colocação poderá dar-se como cumprimento de underwriting firme ou residual, que se entende por subscrição primária, ou, então, pelos tomadores do mercado não envolvidos contratualmente no processo de distribuição, o que será também considerado subscrição primária. Tanto num caso como noutro, não serão colocadas as debêntures enquanto não houver efetivo ingresso do seu produto na companhia. A interpretação do vocábulo na lei é, portanto, restrita, não se podendo entender como tal a simples transferência das debêntures escriturais para o nome dos underwriters, visando a distribuição. Assim é que aquelas debêntures que não forem colocadas, ou seja, pagas à companhia emissora, poderão ser canceladas." (Carvalhosa, ob. cit., p. 812). Pinheiro Guimarães afirma, diferentemente, que "a colocação é o ato de oferecer as debêntures à subscrição" (Debêntures. In: Direito das Companhias. Coord(s).: LAMY FILHO, Alfredo; PEDREIRA, José Luiz Bulhões. $1^{a}$ ed. Rio de Janeiro: Forense, 2009., p. 613), não prevendo a integralização na definição do ato de colocação.

${ }^{221}$ Ob. cit., p. 612.

${ }^{222}$ Ob. cit., p. 814.
} 
transferência, com o registro ou a tradição do bem, a depender de sua natureza. Da mesma forma, não se pode aplicar tal raciocínio ao lançamento de debêntures para pagamento de serviços já realizados ou para dação em pagamento, tendo em vista que em tais casos inexistiria o ingresso de recursos no caixa da sociedade emitente.

A doutrina francesa aborda essa problemática da não colocação das obligations, indagando a respeito da validade do título enquanto estiver nas mãos da sociedade sob dois aspectos. Visto como um empréstimo, o título emitido pelo devedor, enquanto não subscrito pelo credor, não teria existência legal. Ao contrário, considerando a emissão como a criação de títulos destinados à circulação, deve se levar em conta que a sociedade emissora poderá a qualquer momento colocar os títulos no mercado, dando-lhes vida. Pressupõe-se, assim, que os títulos têm existência legal a partir da emissão, mas que a sua validade estaria condicionada à colocação efetiva nas mãos de terceiros. ${ }^{223}$

Ripert e Roblot anotam que a jurisprudência da Corte de Cassação francesa admitia a validade das obrigações criadas pela sociedade e não colocadas em circulação, porém a referida prática passou a ser formalmente condenada a partir da Lei $n^{\circ} 66-537$, de 24 de julho de 1966. O texto normativo em vigor exige que as sociedades francesas cancelem os títulos adquiridos ou não colocados, retirando-os de circulação e inadmitindo a sua recolocação. ${ }^{224}$

Outra questão interessante é abordada pela doutrina italiana: é admissível o penhor de obbligazione não colocada? Trata-se de caso em que a sociedade delibera a emissão do título obrigacional que, ao invés de ser colocado publicamente, é entregue ao credor como garantia de uma outra dívida já existente. Convenciona-se no instrumento de dívida firmado que as obrigações serão alienadas pelo credor, caso a dívida não seja paga, ou, alternativamente, serão resgatadas pela sociedade emissora de acordo com os prazos previstos na escritura de emissão. ${ }^{225}$

\footnotetext{
223 "Les obligations restées entre les mains de la societè ont-elles une valeur juridique? Si on analyse l'emprunt obligataire comme un prêt, il est certain que ce titre, créé par le débiteur alors quu'il n'y a pas de créancier, n'a pas d'existence juridique. Mais si on considère, au contraire, l'émission d'obligations comme une création de titres appelés à circuler, il faut admettre que la société que possède ses propres obligations peut toujours leur donner la vie par la remise à un tiers." (Ob. cit., p. 599) ${ }^{224}$ Ob. cit., p. 599.

${ }^{225}$ LUONI, Sergio. Obbligazioni, Strumenti finanziari, Titoli di Debito Nelle Società di Capitali. Diritto commerciale diretto da Gastone Cottino. Bolonha: Zanichelli, 2010, p. 42.
} 
Parte da doutrina italiana entende que não se trata, precisamente, de um verdadeiro penhor, tendo em vista inexistir a efetiva integralização do título, com a entrega de certa quantia, em bens ou dinheiro, pelo subscritor à sociedade emissora. Esta corrente reconhece um mútuo na base do título.

Sergio Luoni, por sua vez, defende que o título pode ter causa diversa daquela do mútuo, sendo possível a emissão de obrigações, sem o pagamento do preço de emissão, a título de novação ${ }^{226}$ - os títulos seriam entregues ao credor para quitação de dívida préexistente -, de datio in solutum, de promesa acessória ou como documento declaratório de dívida já existente ${ }^{227}$.

Em relação à circulação das debêntures, Rachel Sztajn ensina que a liquidez "é um dos mais importantes instrumentos regulatórios" que influenciam e estimulam os interessados a participar do mercado de valores mobiliários, "seja pela capitalização direta das companhias com a aquisição de ações, seja concedendo empréstimos mediante a aquisição de debêntures". 228

A referida doutrinadora apresenta as definições de circulação e liquidez da seguinte forma:

\begin{abstract}
"Circulação significa movimentação contínua. Indica fluxo, deslocamento, e representa o resultado ou a ação de alguma coisa passar de mão em mão como, por exemplo, a transferência de bens, mercadorias, ou valores entre pessoas: a troca. Em economia, o sentido da palavra circulação indica a transferência ou trânsito de moeda corrente ou títulos em mercados. Circulação é processo em que da troca se permite apurar a rapidez com que os bens mudam de titular ou se convertem em moeda.",229

"Liquidez, em linguagem corrente, é empregada para indicar, em relação ao sujeito, a existência de disponibilidade de dinheiro de contado e, por vezes, outros ativos ou valores (duplicatas, notas promissórias, letras de câmbio) que fácil e imediatamente sejam conversíveis em dinheiro, de que são exemplos comuns títulos e ações. Portanto, liquidez significa ou indica disponibilidade sobre dinheiro, moeda de contado, ou a titularidade sobre bens aptos a serem convertidos em moeda corrente, dinheiro 'vivo', como dizem alguns, facilmente e sem grandes perdas de valor.",30
\end{abstract}

\footnotetext{
${ }^{226}$ Para o direito brasileiro, ocorre novação quando o devedor contrai com o credor nova dívida para extinguir e substituir a anterior (art. 360, I, do Código Civil).

${ }^{227}$ Ob. cit., p. 43.

${ }^{228}$ Conceito de Liquidez na Disciplina do Mercado de Valores Mobiliários. Revista de Direito Mercantil, Industrial, Econômico e Financeiro. Ano XLI. Nova Série. No 126. São Paulo: Malheiros, 2002, pp. 7 e 10.

${ }^{229}$ Ob. cit., p. 10.

${ }^{230}$ Ob. cit., p. 11.
} 
Nesse sentido, a circulação das debêntures depende intrinsecamente da liquidez de um mercado de renda fixa brasileiro. Não basta a colocação primária para estímulo ao mercado de debêntures, pois o interessado não terá como se desfazer de sua posição antes do prazo de vencimento do título. O estímulo à subscrição de debêntures se dá também com a existência de um mercado secundário líquido que permita ao debenturista alienar o título e receber o produto aplicado, sem perdas, antes de seu vencimento ou resgate. Rachel Sztajn ensina que "como a liquidez do mercado secundário é central na decisão de adquirir valores mobiliários, sobretudo novas emissões negociadas em mercado primário, a redução ou desaparecimento da liquidez é causa de afastamento de investidores, seja naquele mercado, seja quanto a um determinado valor mobiliário nele negociado. Portanto, haver ou não liquidez influi sobre decisões de investimento em valores mobiliários."231

Analisaremos à frente, em capítulo específico, os sistemas de registro, custódia, negociação e liquidação das debêntures, bem como a proposta de estímulo à negociação no mercado secundário, por meio da criação de um segmento chamado Novo Mercado de Renda Fixa, que, certamente, visa aumentar a liquidez, tornando-o mais atrativo para a canalização de investimentos.

${ }^{231}$ Ob. cit., p. 19. 


\section{EXTINÇÃO DAS DEBÊNTURES}

À primeira vista, a extinção das debêntures apresenta regime próprio previsto no art. 74 da LSA. A nomenclatura da Seção em que está inserido o referido artigo induz a essa conclusão. Todavia, tal raciocínio é equivocado. Na verdade, o dispositivo mencionado cria deveres legais atribuídos à companhia emissora de realizar as anotações necessárias e de manter arquivados os documentos referentes à extinção das debêntures. Trata-se de procedimento ou iter que deve ser observado após a verificação da extinção. Logo, tem-se que tal dispositivo não revela as causas ou hipóteses pelas quais as debêntures se extinguem.

Nelson Eizirik ensina que as debêntures são extintas por meio "da liquidação, pela companhia emissora, do débito debenturístico mediante o pagamento do seu valor ao titular dos títulos". 232

A primeira, e mais comum, forma de extinção do referido valor mobiliário é o pagamento $^{233}$. Tavares Borba defende, em razão da natureza de "título de dívida e resgate", que o pagamento "representa uma imposição legal inafastável, cujo descumprimento acarreta, para o debenturista, o direito de executar a sociedade, ou de até mesmo requerer a sua falência". 234

A LSA estabelece os seguintes critérios temporais aplicáveis a essa forma de extinção: (i) liquidação integral na data de vencimento prevista na escritura de emissão ou, nas permanentes, nas hipóteses previstas no $\$ 4^{\circ}$ do art. 55 da LSA; e (ii) resgate total antecipado.

Como veremos mais adiante, a amortização parcial e o resgate parcial não ensejam o pagamento integral do título, a menos que ocorram sucessivamente até se chegar à sua liquidação. Isto é, apenas a amortização ou resgate parcial realizados sucessivamente é

\footnotetext{
${ }^{232}$ Ob. cit., p. 452.

${ }^{233}$ Silvio Rodrigues ensina que o pagamento é o fim da obrigação, que decorre de seu cumprimento, "por meio do qual se alcança o objeto por ela perseguido e se põe termo à relação juridica entre o devedor e o credor, liberando-se este último." (Curso de Direito Civil. Parte Geral das Obrigações. Vol. 2. 24a ed. São Paulo: Saraiva, 1996, pp. 115-116)

${ }^{234}$ Ob. cit., p. 58.
} 
que levariam à extinção das debêntures. Caso contrário, antecipam apenas parcialmente o valor a pagar no vencimento, reduzindo-o.

Nuno Barbosa ensina que, para o direito português, "a causa natural de extinção do empréstimo é o seu cumprimento", que pode se dar em um único momento para a totalidade das obrigações (amortização total) ou em diversas oportunidades predefinidas no título (amortização parcial). E vai além, concluindo que "a amortização parcial não tem como efeito a extinção de todas as obrigações - amortização por sorteio - nem necessariamente de qualquer delas - amortização por dedução ao valor nominal."235

A data do vencimento, por sua vez, é requisito ou elemento essencial do negócio jurídico revelado na escritura de emissão ${ }^{236}$, conforme se depreende da leitura do art. 55 da LSA, somente excepcionado na emissão de debêntures permanentes, perpétuas ou openended, as quais não possuem vencimento certo e determinado. Tal requisito, inclusive, existia à época do Decreto ${ }^{\circ} 177-A$ de 1.893 e foi mantido pela LSA.

Para Carvalhosa, "vencimento é a ocorrência da data fixada em contrato ou declaração unilateral de vontade que se determinou para a extinção da obrigação."237

Tavares Borba leciona que "o vencimento permite a execução, marca o início da fluência de juros de mora e deflagra o termo inicial do prazo de prescrição." ${ }^{238}$ Além disso, o vencimento "representa uma imposição legal inafastável"239, que não pode ser objeto de qualquer condicionante que configure um obstáculo ao recebimento do valor devido ao debenturista. ${ }^{240}$

\footnotetext{
${ }^{235}$ Competência das Assembleias de Obrigacionistas. Coimbra: Almedina, 2002, p. 90.

${ }^{236}$ Nelson Eizirik, ob. cit., p. 338. Nessa mesma linha, entendendo que o vencimento é requisito essencial da debênture: Tavares Borba (Ob. cit., p. 58).

${ }^{237}$ Ob. cit., p. 731.

${ }^{238}$ Tavares Borba, ob. cit., p. 59.

${ }^{239}$ Tavares Borba, ob. cit., p. 59.

${ }^{240}$ Tavares Borba (Ob. cit., pp. 59-60) explica, ainda, que algumas emissões realizadas pelas sociedades controladas por instituições financeiras, especialmente as de leasing, condicionam o pagamento ao não desenquadramento do controlador aos limites impostos pelas normas do Conselho Monetário Nacional e do Banco Central do Brasil. Na opinião do referido comercialista, tais cláusulas seriam ilegais e deveriam ser consideradas não escritas.
} 
As debêntures permanentes, por sua vez, extinguem-se nos casos de inadimplemento da obrigação do emissor de pagar juros, de dissolução da companhia ou de outras condições previstas na escritura de emissão, nos termos do $\S 4^{\circ}$ do mencionado artigo.

O resgate total antecipado assemelha-se ao pagamento integral do título, que ocorre na data de seu vencimento, exigindo-se previsão expressa na escritura para que a companhia possa exercer essa faculdade.

Além do vencimento uniforme de uma mesma série, a escritura de emissão poderá prever as hipóteses de amortização ou resgate parcial, como dito acima. A amortização é a extinção da obrigação principal por meio do pagamento em parcelas ou prestações, ao invés de liquidá-la de uma só vez no vencimento, sendo que o resgate é a retirada dos títulos de circulação.

A companhia pode lançar mão da faculdade de resgate ou amortização de uma determinada série por diversos motivos, tais como: (i) mostrar-se excessivamente onerosa, com taxas de juros elevadas; (ii) outras formas de captação de recursos forem mais vantajosas para a rolagem da dívida de longo prazo da companhia; (iii) redução do nível de endividamento da companhia; e (iv) excesso de recursos em caixa e inexistência de projetos para a sua aplicação.

Waldemar Ferreira ensina que "amortizar é, efetivamente, matar ou pagar a dívida, progressivamente. ${ }^{241}$ Leães $^{242}$ esclarece que a amortização, prevista na escritura de emissão, acarreta a redução progressiva e parcial do montante total do débito. Atingindo-se o montante total da obrigação principal, o título é extinto. A sociedade é obrigada a anotar nos registros próprios e retirá-lo de circulação.

Tavares Borba explica que "amortizar significa fazer cessar paulatinamente a obrigação, enquanto resgatar significa retirar títulos (debêntures) de circulação" ${ }^{243}$.

\footnotetext{
${ }^{241}$ Ob. cit., p. 94.

242 Ob. cit., p. 22.

${ }^{243}$ Debêntures. Revista de Direito Mercantil, Industrial, Econômico e Financeiro. Ano XVI. Nova Série. Vol. 26. São Paulo: RT, 1977, p. 140.
} 
Há importantes distinções entre amortização e resgate. Os dois institutos têm regras próprias e produzem efeitos diferenciados. Por exemplo, o plano de amortização deve constar da escritura de emissão e, por conseguinte, obriga a sociedade a cumpri-lo independente de sua vontade, diferentemente do que ocorre no resgate, que também deve ser previsto na escritura, mas que, porém, estabelece um direito potestativo que pode ser exercido, facultativamente, pela sociedade emissora. ${ }^{244}$

A escritura poderá fixar a amortização parcial de cada série, realizando-se rateio quando as debêntures forem da mesma série $\left(\xi^{\circ} \text { do art. } 55 \text { da LSA }\right)^{245}$. O rateio não era previsto na LSA. A sua inserção no $\S 1^{\circ}$ do art. 55 da LSA se deu em razão da modificação promovida pela Lei $\mathrm{n}^{\mathrm{o}} 12.431 / 2.011$, que analisaremos em detalhes mais adiante, distinguindo as regras aplicáveis à amortização e ao resgate parcial, que outrora estavam inadequadamente regulados, conjuntamente, na redação do $\$ 1^{\circ}$ do art. 55 da LSA.

A amortização das debêntures da mesma série deve ser realizada mediante rateio, já o resgate parcial da mesma série deve ser feito por um dos dois modos previstos na LSA, mediante: (i) sorteio; ou (ii) compra, no mercado organizado de valores mobiliários, com a condição de que as debêntures estejam cotadas por preço inferior ao seu valor nominal. Como visto, tem-se aí uma nítida distinção entre amortização e resgate parciais da mesma série.

Ademais, os institutos da amortização e do resgate diferem-se no tocante ao seu exercício. No resgate, há um direito atribuído à companhia de exercer, a qualquer tempo, a faculdade prevista na escritura de retirar, total ou parcialmente, as debêntures do mercado. Já na amortização fala-se em uma obrigação da companhia, sob pena de inadimplemento, de realizar o pagamento parcial de modo a amortizar o valor do título, nos termos da escritura. ${ }^{246}$

\footnotetext{
${ }^{244}$ Para Tavares Borba (Ob. cit., p. 141), "a lei (art. 55) refere-se a estipular amortização e a reservar-se o direito de resgate antecipado, o que dá a entender que, segundo o legislador, a amortização, quando adotada, seria uma obrigação da sociedade, enquanto o resgate configuraria para esta uma mera faculdade.”

245 "Se a escritura estipula a amortização parcial da série mediante pagamento de quantidade ou porcentagem das debêntures em circulação, as debêntures a serem pagas em cada prestação de amortização devem ser determinadas mediante sorteio, salvo quando estiverem cotadas no mercado por preço inferior ao valor nominal, caso em que a companhia pode comprar e cancelar a quantidade das debêntures a serem pagas (art. $\left.55, \S 1^{\circ}\right)$ ". (Pinheiro Guimarães, ob. cit., p. 591).

246 "Na prática, fala-se em amortização e resgate programados como obrigação da emissora, e em amortização e resgate facultativos como decisão espontânea da sociedade segundo seu interesse." (Tavares Borba, Das Debêntures, p. 63)
} 
Como veremos mais adiante, a alteração introduzida pela Lei $n^{0} 12.431 / 2011$ no $\S 1^{\circ}$ do art. 55 da LSA acabou com a celeuma a respeito da possibilidade de vencimentos anuais distintos da mesma série. Atualmente, o referido $\S 1^{\circ}$ trata apenas da amortização da mesma série mediante rateio. Portanto, nesse ponto, o legislador acertou ao corrigir a interpretação equivocada de que as debêntures poderiam ter vencimentos anuais distintos, posto que as debêntures da mesma série devem ser idênticas para que haja mais atratividade e facilidade de circulação no mercado secundário. Imaginem-se debêntures da mesma série com vencimentos distintos. Seria impensável negociá-las em mercado organizado.

Cabe ressaltar, ainda, que a companhia tem a faculdade de criar fundo de amortização, que deve estar previsto na escritura de emissão, conforme previsão do art. $55^{247}$ da LSA.

Parte da doutrina entende que os recursos a serem destinados ao fundo devem ser provenientes de "lucros apurados em balanço, em consonância com o rendimento a que as debêntures fazem jus" ${ }^{\text {248. }}$. Carvalhosa ressalta que a função da criação do fundo de amortização "é a de criar disponibilidade vinculada, de forma a minimizar o impacto de caixa quando do pagamento das amortizações." ${ }^{249}$ Esclarece o comercialista, ainda, que a constituição do fundo deve ocorrer com observância das regras relativas à criação de reservas estatutárias (art. 194 da LSA), devendo: (i) indicar, de modo preciso e completo, a sua finalidade; (ii) fixar os critérios para determinar a parcela anual dos lucros líquidos que serão destinados à sua constituição; e (iii) estabelecer o limite máximo da reserva. ${ }^{250}$

Todavia, inexiste previsão expressa a respeito da obrigatoriedade de se observarem as regras aplicáveis à criação de reservas estatutárias. Pinheiro Guimarães defende que o fundo pode ser constituído mediante "depósito periódico dos recursos a serem utilizados na amortização". ${ }^{251}$ Filiamo-nos a essa corrente, ainda que minoritária, pois

\footnotetext{
247 “Art. 55. A época do vencimento da debênture deverá constar da escritura de emissão e do certificado, podendo a companhia estipular amortizações parciais de cada série, criar fundos de amortizacão e reservar-se o direito de resgate antecipado, parcial ou total, dos títulos da mesma série." (grifo nosso)

${ }^{248}$ Carvalhosa, ob. cit., p. 737.

${ }^{249}$ Ob. cit., p. 737.

${ }^{250}$ Esse entendimento a respeito da observância das regras aplicáveis à criação de reservas estatutárias para a constituição do fundo de amortização é corroborado por Tavares Borba (Ob. cit., p. 66) e Waldecy Lucena (Ob. cit., p. 561), em que pese inexistir previsão expressa que limite a criação de tal fundo com base em parcela do lucro líquido verificado em balanço.

${ }^{251}$ Ob. cit., p. 592.
} 
entendemos que os procedimentos de constituição e funcionamento do fundo de amortização devem ser estabelecidos livremente na escritura de emissão, em homenagem ao princípio da liberdade contratual, tendo em vista a inexistência de norma expressa a esse respeito.

Ainda, aliando teoria e prática, Pinheiro Guimarães destaca os aspectos essenciais que devem constar na escritura de emissão que cria o fundo de amortização, a saber:

“[...] instituição financeira na qual será mantido o fundo de amortização, as restrições de movimentação a que os recursos depositados no fundo de amortização ficarão sujeitos, a periodicidade e o montante das contribuições para o fundo a serem feitas pela companhia emissora, o montante total a ser depositado no fundo e o prazo para constituição deste montante. A escritura de emissão deverá prever, ainda, o direito de livre acesso do agente fiduciário às informações referentes ao fundo de amortização."252

Os aspectos sugeridos pelo ilustre comercialista parecem fazer mais sentido pois referem-se à segregação dos recursos para constituição do fundo de amortização. Trata-se de destinação de valor constante no caixa da companhia para conta específica que seria destinada à futura amortização das debêntures, tornando o fundo líquido e disponível no curto prazo. O fundo, neste caso, estaria contabilizado no ativo da companhia, contrariamente àquela posição defendida por Carvalhosa em que se contabilizaria em conta do patrimônio líquido (reserva estatutária), prejudicando a disponibilidade imediata se a companhia não tiver recursos suficientemente disponíveis em caixa.

Leães, baseando-se na doutrina norte-americana ${ }^{253}$, ensina que a criação de um fundo próprio destinado à amortização das debêntures é conhecido como sinking fund, destacando quatro tipos de fundos que se diferenciam pelo critério utilizado para sua formação:

“[...] a) noncumulative sinking fund, constituído com a distração de um montante fixo dos lucros de balanço, para amortização anual de um determinado volume de títulos; b) cumulative sinking fund, constituído com a distração de um percentual anual dos lucros de balanço; c) per unit of output, constituída das empresas que exploram alguma coisa ou atividade de

\footnotetext{
${ }^{252}$ Ob. cit., p. 592.

${ }^{253}$ Leães cita as obras The Financial Policy of Corporations, de Dewing (4a ed. New York, 1953, p. 260) e Ballantines on Corporations, de Henry Winthrop Ballantine (Chicago, 1946, p. 498).
} 
duração limitada, tal como a utlização de uma patente de invenção que, com o tempo, cai em domínio público, ou a extração de mina, que se exaure; e $d$ ) fundo de valor decrescente (variable annual amounts), acompanhando a redução gradual do empréstimo debenturístico."254

Ballantine, citado por Leães, revela que os chamados sinking funds são formados a partir de pagamentos realizados ao sinking fund agent e condicionados ao net earnings (net profits). Interessante destacar, ainda, que alguns Estados americanos reconhecem certos direitos aos titulares dos títulos de dívida (bondholders), tais como o direito de fiscalizar e o direito de voto, a partir do não pagamento de juros ou do descumprimento pela companhia de obrigações de não fazer (negative covenants) fixadas na escritura de emissão. ${ }^{255}$

Após analisarmos a amortização e resgate do título, temos que, além do pagamento, o valor mobiliário ora em estudo pode ser extinto por meio de conferência para integralização de nova emissão de debêntures da mesma companhia, configurando a extinção do título em razão da dação em pagamento (para o detentor do título original, que recebe novas debêntures em troca da entrega das anteriores a título de integralização) e pela ocorrência de confusão (a companhia, ao receber as debêntures já emitidas para integralização da nova emissão, poderá extingui-las), salvo, nesta última hipótese, em razão da opção da companhia de mantê-las em tesouraria, situação que será analisada mais adiante, quando tratarmos dos negócios jurídicos operados com o uso de debêntures.

Com relação ao meio de pagamento, as debêntures podem ser extintas mediante a entrega, pela sociedade emissora aos debenturistas, de dinheiro ou bens. A doutrina afirma que a liquidação deve ser realizada, a princípio, em dinheiro, reconhecendo aí uma hipótese de dação em pagamento sujeita à concordância dos credores. Trata-se de obrigação alternativa da sociedade emissora, cuja escolha recai sobre o credor (ver art. 54, $\S 2^{\circ}$, da LSA).

\footnotetext{
${ }^{254}$ Leães, ob. cit., p. 23.

255 Ob. cit., p. 498.
} 
Por fim, outra questão interessante, ainda em matéria de extinção das debêntures, é saber se a extinção do título também dá causa à extinção da organização de obrigacionistas - unidade que se forma e se organiza a partir da comunhão ou convergência de interesses visando um mesmo fim. Analisaremos em detalhes essa problemática quando ingressarmos mais à frente no capítulo relativo à tutela dos debenturistas. 


\section{BIBLIOGRAFIA}

\section{Doutrina Nacional}

ADAMEK, Marcelo Vieira Von. Responsabilidade dos Administradores de S/A e as Ações Correlatas. São Paulo: Saraiva, 2009.

Temas de Direito Societário e Empresarial Contemporâneos. Liber Amicorum Prof. Dr. Erasmo Valladão Azevedo e Novaes França. São Paulo: Malheiros, 2011.

AMARAL, Francisco. Direito Civil. Introdução. $7^{\text {a }}$ ed. Rio de Janeiro: Renovar, 2008.

AMARAL, Hermano de Villemor. Das Sociedades Limitadas. 2a ed. Rio de Janeiro: F. Briguiet \& Cia., 1938.

AMARAL, José Romeu Garcia do. Quorum na Nova Sociedade Limitada. In: Sociedade Limitada Contemporânea. Coleção IDSA. Coord(s): AZEVEDO, Luís André N. de Moura; CASTRO, Rodrigo R. Monteiro de. São Paulo: Quartier Latin, 2013.

ARAGÃO, Leandro Santos de; CASTRO, Rodrigo R. Monteiro de. Direito Societário. Desafios Atuais. São Paulo: Quartier Latin, 2009.

ASCARELLI, Tullio. Principios y Problemas de las Sociedades Anonimas. México: Imprenta Universitaria, 1951.

Problemas das Sociedades Anônimas e Direito Comparado. $1^{\mathrm{a}}$ reimpresão. São Paulo: Quorum, 2008.

Teoria Geral dos Títulos de Crédito. Campinas: Servanda, 2009.

Iniciação ao Estudo do Direito Mercantil. Sorocaba: Minelli, 2007.

Panorama do Direito Comercial. São Paulo: Saraiva, 1947.

ASCENSÃO, José Oliveira. Direito Civil. Teoria Geral. Relações e Situações Jurídicas. Vol. 3. $2^{\mathrm{a}}$ ed. São Paulo: Saraiva, 2010.

AZEVEDO, Antonio Junqueira. Novos Estudos e Pareceres de Direito Privado. $1^{\mathrm{a}}$ ed. $2^{\mathrm{a}}$ tiragem. São Paulo: Saraiva, 2010.

AZEVEDO, Luís André N. de Moura; CASTRO, Rodrigo R. Monteiro de (Coords.). Sociedade Limitada Contemporânea. Coleção IDSA. São Paulo: Quartier Latin, 2013. 
CASTRO, Rodrigo R. Monteiro de. Poder de Controle e Outros Temas de Direito Societário e Mercado de Capitais. São Paulo: Quartier Latin, 2010.

BORBA, José Edwaldo Tavares. Das Debêntures. Rio de Janeiro: Renovar, 2005.

Direito Societário. 10ª ed. Rio de Janeiro: Renovar, 2007.

Debêntures. Revista de Direito Mercantil, Industrial, Econômico e Financeiro. Ano XVI. Nova Série. Vol. 26. São Paulo: RT, 1977.

BORGES, João Eunápio. Títulos de Crédito. $2^{\mathrm{a}}$ ed. Rio de Janeiro: Forense, 1971.

BULGARELLI, Waldirio. Sociedades, Empresa e Estabelecimento. São Paulo: Atlas, 1980. . Manual das Sociedades Anônimas. $4^{\mathrm{a}}$ ed. São Paulo: Atlas, 1987.

CALDEIRA, Jorge. A Nação Mercantilista. São Paulo: Ed. 34, 1999.

CAMARGO, André Antunes Soares de. Transações entre Partes Relacionadas. Um desafio Regulatório Complexo e Multidisciplinar. São Paulo: Almedina, 2013.

CARVAlHOSA, Modesto. Comentários à Lei de Sociedades Anônimas. $1^{\circ}$ Vol. $6^{\mathrm{a}}$ ed. São Paulo: Saraiva, 2011.

. EIZIRIK, Nelson. Estudos de Direito Empresarial. São Paulo: Saraiva, 2010.

As Poison Pills Estatutárias na Prática Brasileira - Alguns Aspectos de sua Legalidade. In: Direito Societário. Desafios Atuais. Coord.: CASTRO, Rodrigo R. Monteiro; ARAGÃO, Leandro Santos de. São Paulo: Quartier Latin, 2009.

CASTRO, Marina Grimaldi. Debêntures: forma de captação de recursos no mercado de capitais brasileiro. Belo Horizonte: Del Rey, 2010.

CASTRO, Rodrigo R. Monteiro de. Controle Gerencial. Coleção IDSA. Vol 2. São Paulo: Quartier Latin, 2010.

. ARAGÃO, Leandro Santos de. Direito Societário. Desafios Atuais. São Paulo: Quartier Latin, 2009.

. AZEVEDO, Luís André N. de Moura. Poder de Controle e Outros Temas de Direito Societário e Mercado de Capitais. São Paulo: Quartier Latin, 2010.

. AZEVEDO, Luís André N. de Moura. Sociedade Limitada Contemporânea. Coleção IDSA. São Paulo: Quartier Latin, 2013. 
WARDE JÚNIOR, Walfrido Jorge; GUERREIRO, Carolina Dias Tavares. Direito Empresarial e Outros Estudos de Direito em Homenagem ao Professor José Alexandre Tavares Guerreiro. São Paulo: Quartier Latin, 2013.

COMPARATO, Fábio Konder. Ensaios e Pareceres de Direito Empresarial. Rio de Janeiro: Forense, 1978.

. Direito Empresarial. Estudos e Pareceres. $1^{\text {a }}$ ed. São Paulo: Saraiva, 1990.

Poder de Controle nas Sociedades Anônimas. 5ª ed. Rio de Janeiro: Forense, 2008.

COSTA, Philomeno J. da. As Partes Beneficiárias. São Paulo: Saraiva, 1965.

. Aspectos da Sociedade por Ações. Vol. 72. Separata da Revista da Faculdade de Direito, 1977.

EIZIRIK, Nelson. A Lei das S/A Comentada. Vol I. São Paulo: Quartier Latin, 2011.

2010 .

CARVAlHOSA, Modesto. Estudos de Direito Empresarial. São Paulo: Saraiva,

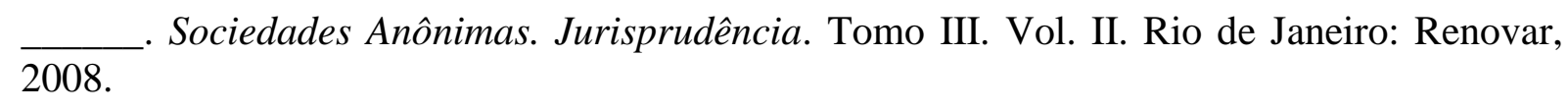

. GAAL, Ariádna B.; PARENTE, Flávia; HENRIQUES, Marcus de Freitas. Mercado de Capitais. Regime Jurídico. $2^{\mathrm{a}} \mathrm{ed}$. Rio de Janeiro: Renovar, 2008.

. Sociedades Anônimas. Jurisprudência. Rio de Janeiro: Renovar, 1996.

FERREIRA, Aurélio Buarque de Holanda. Novo Aurélio Século XXI; o dicionário da língua portuguesa. $3^{\text {a }}$ ed. Rio de Janeiro: Nova Fronteira, 1999.

FERREIRA, Waldemar Martins. Tratado das Debênturas. $1^{\circ}$ Vol. Rio de Janeiro: Ed. Freitas Bastos, 1944. 1958.

Instituições de Direito Comercial. Vol. 3. Tomo I. $4^{\text {a }}$ ed. São Paulo: Max Limonad,

FRANCO, Vera Helena de Mello. Direito Empresarial I: o empresário e seus auxiliares, o estabelecimento empresarial, as sociedades. $3^{\mathrm{a}}$ ed. São Paulo: RT, 2009.

FRANÇA, Erasmo Valladão Azevedo e Novaes. Conflito de Interesses nas Assembleias de S.A. São Paulo: Malheiros, 1993.

Malheiros, 2009. 
Temas de Direito Societário e Empresarial Contemporâneos. São Paulo: Malheiros, 2011.

. Direito Societário Contemporâneo I. São Paulo: Quartier Latin, 2009.

Invalidade das Deliberações de Assembleia das S.A. São Paulo: Malheiros, 1999.

Da Assembléia-Geral de Credores. In: Comentários à Lei de Recuperação de Empresas e Falência. Coord.: SOUZA JÚNIOR, Francisco Satiro; PITOMBO, Antonio Sérgio A. de Moraes. $2^{a}$ ed. São Paulo: RT, 2007.

GOMES, Laurentino. 1808. $4^{\mathrm{a}}$ reimpressão. São Paulo: Planeta, 2007.

GONÇALVES NETO, Alfredo de Assis. Manual das Companhias ou Sociedades Anônimas. $2^{\mathrm{a}}$ ed. reformulada da obra Lições de Direito Societário II - Sociedade Anônima. São Paulo: RT, 2010.

GUIMARÃES, Francisco José Pinheiro. Debêntures. In: Direito das Companhias. Coord(s). LAMY FILHO, Alfredo; PEDREIRA, José Luiz Bulhões. $1^{a}$ ed. Rio de Janeiro: Forense, 2009.

GUERREIRO, Carolina Dias Tavares; WARDE JÚNIOR, Walfrido Jorge; CASTRO, Rodrigo R. Monteiro de. Direito Empresarial e Outros Estudos de Direito em Homenagem ao Professor José Alexandre Tavares Guerreiro. São Paulo: Quartier Latin, 2013.

GUERREIRO, José Alexandre Tavares; TEIXEIRA, Egberto Lacerda. Das Sociedades Anônimas no Direito Brasileiro. Vol. 1. São Paulo: Bushatsky, 1979.

Interpretação de Preferências na Lei de S/A. In: Temas de Direito Societário e Empresarial Contemporâneos. Liber Amicorum Prof. Dr. Erasmo Valladão Azevedo e Novaes França. Coord.: ADAMEK, Marcelo Vieira Von. São Paulo: Malheiros, 2011.

LACERDA, J.C. Sampaio. Curso de Direito Comercial Marítimo e Aeronáutico. $6^{\mathrm{a}}$ ed. Rio de Janeiro: Livraria Freitas Bastos, 1963.

LAMY FILHO, Alfredo; PEDREIRA, José Luiz Bulhões. Direito das Companhias. Vol. I. Rio de Janeiro: Ed. Forense, 2009.

A Lei das S.A. Pressupostos, Elaboração e Modificações. Vol. I. $3^{\text {a }}$ ed. Rio de Janeiro: Renovar, 1997.

Exposições. Pareceres. Rio de Janeiro: Renovar, 2007.

LEÃES, Luiz Gastão Paes de Barros. Comentários à Lei das Sociedades Anônimas. São Paulo: Saraiva, 1980. 
Estudos e Pareceres sobre Sociedades Anônimas. São Paulo: RT, 1989.

Pareceres. São Paulo: Singular, 2004.

LIMA, Otto de Souza. Negócio Fiduciário. São Paulo: RT, 1962.

LUCCA, Newton de. As Bolsas de Valores e os Valores Mobiliários. In: Simpósio sobre Direito dos Valores Mobiliários. Série Cadernos do Conselho da Justiça Federal. N. 16. Brasília: CJF, 1999, p. 131.

LUCENA, José Waldecy Lucena. Das Sociedades Anônimas. Comentários à Lei. Vol. I. Rio de Janeiro: Renovar, 2009.

MARGONI, Anna Beatriz Alves; SILVEIRA, Susana Amaral. A Administração das Sociedades Anônimas. In: Direito Societário Contemporâneo I. Coord.: FRANÇA, Erasmo Valladão Azevedo e Novaes. São Paulo: Quartier Latin, 2009.

MARTINS, Fran. Títulos de Crédito. 15ª ed. Rio de Janeiro: Forense, 2010.

Comentário à Lei das Sociedades Anonimas. 4ª ed. Rio de Janeiro: Forense, 2010.

MAXIMILIANO, Carlos. Hermenêutica e Aplicação do Direito. $18^{\mathrm{a}}$ ed. Rio de Janeiro: Ed. Forense, 2000.

MELlO, Celso Antônio Bandeira de. Curso de Direito Administrativo. 12a ed. São Paulo: Malheiros, 2000.

MENDONÇA, José Xavier Carvalho de. Tratado de Direito Comercial Brasileiro. Vol. IV. Livro II. $4^{\mathrm{a}}$ ed. Rio de Janeiro: Freitas Bastos, 1946.

MESSINA, Paulo de Lorenzo; FORGIONI, Paula A. A Posição dos Tribunais Perante as Sociedades Por Ações (1986-1997). Relatório de Pesquisa $n^{\circ}$ 9/1999. São Paulo: EAESP/FGV/NPP - Núcleo de Pesquisas e Publicações, 1999.

MIRANDA, Pontes de. Tratado de Direito Privado. Parte Especial. Tomos L e LI. $3^{\text {a }}$ ed. Rio de Janeiro: Borsoi, 1972.

. Tratado de Direito Privado. Parte Especial. Tomo XXXIII. $2^{\mathrm{a}}$ ed. Rio de Janeiro: Borsoi, 1961. 1954.

Tratado de Direito Cambiário. Letra de Câmbio. Vol I. São Paulo: Max Limonad, 
MOTTA, Rita de Cássia Luz Teixeira. O Conceito de Valor Mobiliário no Direito Brasileiro. Dissertação de Mestrado apresentada à Faculdade de Direito da Universidade de São Paulo, 2002.

MUNHOZ, Eduardo Secchi. Aquisição de Controle na Sociedade Anônima. São Paulo: Saraiva, 2013.

MUNIZ, Ian; BRANCO, Adriano Castello. Aspectos Fiscais e Societários. São Paulo: Quartier Latin, 2007.

MÜSSNICH, Francisco Antunes Maciel. As recentes alterações com respeito à competência para emissão de debêntures. In: Direito Empresarial e outros estudos em homenagem ao Professor José Alexandre Tavares Guerreiro. São Paulo: Quartier Latin, 2013.

OIOLI, Erik Frederico. Oferta Pública de Aquisição do Controle de Companhias Abertas. Coleção IDSA. Vol. 1. São Paulo: Quartier Latin, 2010.

VEIGA, Marcelo Godke. As Sociedades Limitadas e o Mercado de Capitais. In: Sociedade Limitada Contemporânea. Coleção IDSA. Coord(s): AZEVEDO, Luís André N. de Moura; CASTRO, Rodrigo R. Monteiro de. São Paulo: Quartier Latin, 2013.

OLIVEIRA, J. Lamartine Corrêa de. A Dupla Crise da Pessoa Jurídica. São Paulo: Saraiva, 1979.

PARGENDLER, Mariana. Evolução do Direito Societário. Lições do Brasil. São Paulo: Saraiva, 2013.

PAULA, Luiz de. Debêntures (Obrigações). São Paulo: Contasa, 1971.

PEDREIRA, José Luiz Bulhões; LAMY FILHO, Alfredo. Direito das Companhias. Vol. I. Rio de Janeiro: Ed. Forense, 2009.

A Lei das S.A. Pressupostos, Elaboração e Modificações. Vol. I. $3^{\text {a }}$ ed. Rio de Janeiro: Renovar, 1997.

Exposições. Pareceres. Rio de Janeiro: Renovar, 2007.

PENTEADO, Mauro Rodrigues. Títulos de Crédito. Teoria Geral e Títulos Atípicos em Face do Novo Código Civil. São Paulo: Walmar, 2004.

PITOMBO, Antônio Sérgio A. de Moraes; SOUZA JÚNIOR, Francisco Satiro de. Comentários à Lei de Recuperação de Empresas e Falência. 2a ed. São Paulo: RT, 2007. 
PITTA, André Grünspun. A Possibilidade de Emissão de Debêntures por Sociedade Limitada Regida Supletivamente pela Lei das Sociedades por Ações. In: Sociedade Limitada Contemporânea. Coleção IDSA. Coord(s): AZEVEDO, Luís André N. de Moura; CASTRO, Rodrigo R. Monteiro de. São Paulo: Quartier Latin, 2013.

PRADO JÚNIOR, Caio. História Econômica do Brasil. $7^{\text {a }}$ edição. São Paulo: Brasiliense, 1962.

REQUIÃO, Rubens. Comentários à Lei das Sociedades Anônimas. Vol 1. São Paulo: Saraiva, 1978.

. Curso de Direito Comercial. Vol. 1. São Paulo: Saraiva, 1995.

ROCCO, Alfredo. Princípios de Direito Comercial. Campinas: LZN, 2003.

RODRIGUES, Silvio. Curso de Direito Civil. Parte Geral das Obrigações. Vol 2. $24^{\mathrm{a}}$ ed. São Paulo: Saraiva, 1996.

Direito Civil. Parte Geral. Vol. 1. 34ª ed. São Paulo: Saraiva, 2003.

Direito Civil Aplicado. $1^{\text {o }}$ Vol. $2^{\text {a }}$ ed. São Paulo: Saraiva, 1988.

RODRIGUES, Sofia Nascimento. A Proteção dos Investidores em Valores Mobiliários. Coimbra: Almedina, 2001.

RUSSELL, Alfredo. Sociedades Anonymas. 2a ed. Rio de Janeiro: Livraria Jacintho, 1937.

SALOMÃO, Calixto. O Novo Direito Societário. $3^{\mathrm{a}}$ ed. São Paulo: Malheiros, 2006.

Recuperação de Empresas e Interesse Social. In: Comentários à Lei de Recuperação de Empresas e Falência. Coord.: SOUZA JÚNIOR, Francisco Satiro de; PITOMBO, Antônio Sérgio A. de Moraes. $2^{a}$ ed. São Paulo: RT, 2007.

SOUZA, Carlos Aurélio Mota; LOMÔNACO, José Antônio. Debêntures. Atualidade e Disciplina Segundo a Lei das Sociedades Anônimas. $1^{a}$ ed. Bauru: Jalovi, 1990.

SOUZA JÚNIOR, Francisco Satiro de; PITOMBO, Antônio Sérgio A. de Moraes. Comentários à Lei de Recuperação de Empresas e Falência. 2a ed. São Paulo: RT, 2007.

SOUZA, H. Inglez. Títulos ao Portador no Direito Brazileiro. Rio de Janeiro: Livraria de Francisco Alves, 1898.

SPINELLI, Luis Felipe. Conflito de Interesses na Administração da Sociedade Anônima. São Paulo: Malheiros, 2012. 
SHIGUEMATSU, Plinio José Lopes. Mecanismos de Proteção e Estratégias de Defesa em Tomadas Hostis de Controle. In: Direito Societário. Desafios Atuais. Coord.: CASTRO, Rodrigo R. Monteiro; ARAGÃ̃, Leandro Santos de. São Paulo: Quartier Latin, 2009.

SZTAJN, Rachel. Da Recuperação Judicial. In: Comentários à Lei de Recuperação de Empresas e Falência. Coord.: SOUZA JÚNIOR, Francisco Satiro de; PITOMBO, Antônio Sérgio A. de Moraes. 2a ed. São Paulo: RT, 2007.

FRANCO, Vera Helena de Mello. Direito Empresarial II. Sociedade Anônima. Mercado de Valores Mobiliários. 2a ed. São Paulo: RT, 2009.

TEIXEIRA, Egberto Lacerda. Das Sociedades por Quotas de Responsabilidade Limitada. São Paulo: Max Limonad, 1956.

GUERREIRO, José Alexandre Tavares. Das Sociedades Anônimas no Direito Brasileiro. Vol. 1. São Paulo: Bushatsky, 1979.

TOLEDO, Paulo Fernando Campos Salles de. Poison Pill: Modismo ou Solução? In: Direito Societário. Desafios Atuais. Coord.: CASTRO, Rodrigo R. Monteiro; ARAGÃO, Leandro Santos de. São Paulo: Quartier Latin, 2009.

VALVERDE, Trajano de Miranda. Sociedade por Ações. Vol. II. $3^{a}$ ed. Rio de Janeiro: Forense, 1959.

VAZ, Ernesto Luís Silva; NASCIMENTO, João Pedro Barroso do. Poderes da administração na oferta hostil de aquisição de controle no direito comparado (medidas defensivas e poison pills). In: Direito Societário Contemporâneo I. Coord.: FRANÇA, Erasmo Valladão Azevedo e Novaes. São Paulo: Quartier Latin, 2009.

VEIGA, Alexandre Brandão da. Transmissão de Valores Mobiliários. Coimbra: Almedina, 2010 .

VEIGA, Marcelo Godke; OIOLI, Erik Frederico. As Sociedades Limitadas e o Mercado de Capitais. In: Sociedade Limitada Contemporânea. Coleção IDSA. Coord(s): AZEVEDO, Luís André N. de Moura; CASTRO, Rodrigo R. Monteiro de. São Paulo: Quartier Latin, 2013.

VERÇOSA, Haroldo Malheiros Duclerc. Curso de Direito Comercial. Vol. 2. São Paulo: Malheiros, 2006.

Curso de Direito Comercial. Vol. 3. São Paulo: Malheiros, 2007.

WARDE JÚNIOR, Walfrido Jorge; CASTRO, Rodrigo R. Monteiro de; e GUERREIRO, Carolina Dias Tavares. Direito Empresarial e Outros Estudos de Direito em Homenagem ao Professor José Alexandre Tavares Guerreiro. São Paulo: Quartier Latin, 2013. 
ZANINI, Carlos Klein. A Poison Pill Brasileira: Desvirtuamento, Antijuridicidade e Ineficiência. In: Temas de Direito Societário e Empresarial Contemporâneos. Liber Amicorum Prof. Dr. Erasmo Valladão Azevedo e Novaes França. Coord.: ADAMEK, Marcelo Vieira Von. São Paulo: Malheiros, 2011.

\section{Doutrina Estrangeira}

ABBADESSA, P.; PORTALE, G. B. Il Nuovo Diritto Delle Società. Liber Amicorum Gian Franco Campobasso. Vol. 1. Turim: UTET, 2007.

ABREU, Jorge Manuel Coutinho de. Da Empresarialidade. As Empresas no Direito. Coimbra: Almedina, 1999.

ANGELICI, Carlo. Attivitá e Organizzazione. Studi di Diritto Delle Società. Turim: G. Giappichelli, 2007. Milani, 2006.

La Riforma delle Società di Capitali. $2^{\mathrm{a}}$ ed. Pádua: Casa Editrice Dott. Antonio

ANTUNES, José A. Engrácia. Direito das Sociedades Comerciais. Perspectivas do seu ensino. Coimbra: Almedina, 2000.

ARRILLAGA, Jose Ignacio de. Emision de Obligaciones y Proteccion de los Obligacionistas. Madrid: Revista de Derecho Privado, 1952.

ASCENSÃO, José de Oliveira. Direito Civil. Teoria Geral. Relações e Situações Jurídicas. Vol. 3. $2^{\text {a }}$ ed. São Paulo: Saraiva, 2010.

AUTUORI, Luca. Organizzazione degli obbligazionisti. In: Commentario alla Riforma Delle Società. Obbligazioni. Bilancio. Org.: MARCHETTI, Piergaetano et. al. Milão: Egea Giuffrè, 2006.

BAINBRIDGE, Stephen M. Mergers and Acquisitions. Nova Iorque: Foundation Press, 2003.

BALLANTINE, Henry Winthrop. Ballantine on Corporations. Chicago: Callaghan, 1946.

BARBOSA, Nuno. Competência das Assembleias de Obrigacionistas. Coimbra: Almedina, 2002.

BERGEL, Jean-Louis. Teoria Geral do Direito. São Paulo: Martins Fontes, 2006. 
BERLE, Adolf A.; MEANS, Gardiner C. The Modern Corporation \& Private Property. New Jersey: Transaction Publishers, 2009.

BERTACHINI, Elisabetta et. al. Commentário delle Società. A cura di Giovanni Grippo. Tomo I. Turim: UTET, 2009.

BESSONE, Mario. Imprese e Società. Lineamenti di Diritto Commerciale. Roma: Laterza, 2001.

BIANCHI, Antonio. Manuale dele Società di Capitali. Società di Persone, imprese e mercati. Annotato con la Giurisprudenza e Focus Fiscale. Lavis: CEDAM, 2012.

BLAIR, Margaret. Ownership and Control: Rethinking Corporate Governance for the Twenty-First Century. In: Theories of Corporate Governance. Org.: CLARKE, Thomas. Londres: Routledge, 2007.

BORGIA, Rossella Cavallo. Azioni e Obbligazioni di Società. Pádua: CEDAM, 1988.

BOWN, Stephen R. Merchant Kings. When Companies Ruled the World, 1600-1900. Nova Iorque: Thomas Dunne, 2009.

BUONOCORE, Vincenzo. Manuale di Diritto Commerciale. 10ª ed. Turim: G. Giappichelli, 2011.

. Trattato di Diritto Commerciale. L'Impresa. Seção I. Tomo 2.I. Turim: G. Giappicheli, 2002.

CALERO, Fernando Sánchez; GUILARTE, Juan Sánchez-Calero. Instituciones de Derecho Mercantil. Vol. I. 30ª ed. Navarra: Thomson-Aranzadi, 2007.

CÂMARA, Paulo. Manual de Direito dos Valores Mobiliários. Coimbra: Almedina, 2009.

CAMPOBASSO, G.F. Diritto Commerciale. Diritto Delle Società. $6^{\text {a }}$ ed. Turim: UTET Giuridica, 2007.

CAWSTON, George; KEANE, A. H. The Early Chartered Companies (A.D. 1296-1858). Honolulu: University Press of the Pacific, 2004.

CLARK, Robert Charles. Corporate Law. Boston: Little Brown, 1986.

CLARKE, Thomas. Theories of Corporate Governance. Londres: Routledge, 2007. 
COFFEE JR., John C.; SELIGMAN, Joel; SALE, Hillary A. Securities Regulation. Cases and Materials. $10^{\mathrm{a}}$ ed. Nova Iorque: Foundation Press, 2007.

CORDEIRO, António Menezes. Código das Sociedades Comerciais Anotado. $2^{\mathrm{a}}$ ed. Coimbra: Almedina, 2012. . Manual de Direito das Sociedades. $2^{\mathrm{a}}$ ed. Coimbra: Almedina, 2007. Banca, Bolsa e Crédito. Estudos de Direito Comercial e de Direito da Economia. V. I. Coimbra: Almedina, 1990. . Direito das Sociedades VI. $3^{\mathrm{a}}$ ed. Coimbra: Almedina, 2011. . Direito Comercial. $3^{\mathrm{a}}$ ed. Coimbra: Almedina, 2012.

CORSINI, Alessandro et. al. Le Società a Responsabilità Limitata. Commentario pratico. Verona: Euroconference, 2013.

COX, James D.; HAZEN, Thomas Lee. Corporations. $2^{\mathrm{a}}$ ed. New York: Aspen Publishers, 2003.

COZIAN, Maurice; VIANDIER, Alain; DEBOISSY, Florence. Droit des Sociétés. $18^{\mathrm{a}}$ ed. Paris: Litec, 2005.

CUNHA, Paulo Olavo. Direito das Sociedades Comerciais. $5^{\mathrm{a}}$ ed. Coimbra: Almedina, 2012.

CURRY, William. The Commentaries of Sir William Blackstone, Knt. on the Laws and Constitution of England. Londres: Elibron Classics, 2005. Reprodução original da edição publicada em 1796.

DEBOISSY, Florence; e WICKER, Guillaume. Code des Societies et Autres Groupements. $6^{\mathrm{a}}$ ed. Paris: LexisNexis, 2012.

2005.

COZIAN, Maurice; e VIANDIER, Alain. Droit des Sociétés. 18ª ed. Paris: Litec,

DEWING, Arthur Stone. The Financial Policy of Corporations. $4^{\mathrm{a}}$ ed. Nova Iorque, 1953.

DIAZ-CAÑABATE, Joaquín Garrigues. Negocios fiduciarios en el Derecho Mercantil. Madri: Civitas, 1978. 1982.

Problemas Atuais das Sociedades Anônimas. Porto Alegre: Sergio Antonio Fabris,

DUARTE, Rui Pinto. O Ensino do Direito das Sociedades. Lisboa: Coimbra, 2008. 
ENTERRIA, Javier Garcia de. Le Obbligazioni Convertibili in Azioni. Milão: Giuffrè, 1989.

FERRARA JR., Francesco; CORSI, Francesco. Gli Imprenditori e Le Società. Milão: Giuffrè, 2011.

FERREIRA, Amadeu José. Valores Mobiliários Escriturais. Um novo modo de representação e circulação de direitos. Coimbra: Almedina, 1997.

FERRI, Giuseppe. Manuale di Diritto Commerciale. 30ª ed. Turim: UTET, 2010. Le Società. $2^{\mathrm{a}}$ ed. Turim: UTET, 1985.

GALGANO, Francesco. Diritto Commerciale. Le Società. 17ª ed. Bolonha: Zanichelli, 2009. GENGHINI, Riccardo. Trattato di Diritto Commerciale e di Diritto Pubblico Dell'Economia. Vol. 29. Tomo I. $3^{\text {a }}$ ed. Pádua: CEDAM, 2006.

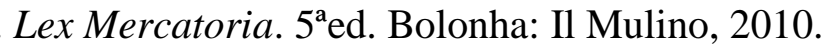

GAMBINO, Agostino; SANTOSUOSSO, Daniele U. Fondamenti di Diritto Commerciale (a cura di Agostino Gambino). Società di Capitali. Vol II. $3^{\text {a }}$ ed. Turim: G. Giappichelli, 2010.

GARNER, Bryan A. Black's Law Dictionary. 8ª ed. St. Paul: West, 2004.

GAUGHAN, Patrick A. Mergers and Acquisitions and Corporate Restructuring. $4^{\mathrm{a}}$ ed. New Jersey: John Wiley \& Sons, 2007.

GIANCOLA, Francesco. Commentário dele Società, a cura di Giovanni Grippo. Turim: UTET, 2009.

GIANNELLI, Andrea. Delle Obbligazioni. In: Commentario alla riforma delle società. Obbligazioni e Bilancio. A cura di Mario Notari e Luigi A. Bianchi. Coord.: MARCHETTI, Piergatano et. al. $1^{\text {a }}$ ed. Milão: Egea - Giuffrè, 2006.

GILSON, Ronald J.; BLACK, Bernard S. The Law and Finance of Corporate Acquisitions. $2^{\mathrm{a}}$ ed. Westbury: The Foundation Press, 1995.

GRIFFITHS, Sir Percival. A Licence to Trade. A History of the English Chartered Companies. Londres: Ernest Benn, 1974.

GUYON, Yves. Droit des Affaires. Tomo 1. 12 ed. Paris: Economica, 2003.

HAAS, Jeffrey J. Corporate Finance. St. Paul: West, 2004. 
HANSMANN, Henry. The Ownership of Enterprise. Londres: Harvard University Press, 1996.

. KRAAKMAN, Reinier R. et. al. The Anatomy of Corporate Law. A Comparative and Functional Approach. Oxford: Oxford University Press, 2004.

JAEGER, Pier Giusto; DENOZZA, Francesco; TOFFOLETTO, Alberto. Appunti di Diritto Commerciale. Impresa e Società. $7^{\mathrm{a}}$ ed. Milão: Giuffrè, 2010.

JORDAN, Herbert W. Debentures and other charges. Londres: Jordan \& Sons, 1914. Reprodução do original da Biblioteca da Harvard Law School.

KRAAKMAN, Reinier R. et. al. The Anatomy of Corporate Law. A Comparative and Functional Approach. Oxford: Oxford University Press, 2004.

LARENZ, Karl. Metodologia da Ciência do Direito. $2^{\mathrm{a}}$ ed. Lisboa: Fundação Calouste Gulbenkian, 1983.

LATTIN, Norman D. The Law of Corporations. $2^{\mathrm{a}}$ ed. Nova Iorque: Foundation Press, 1971.

LE CANNU, Paul. Droit des Societès. 2a ed. Paris: Montchrestien, 2003.

LEVIN, Jack S. Structuring Venture Capital, Private Equity, and Entrepreneurial Transactions. Frederick: Aspen Publishers, 2007.

LORDI, Luigi. Le Obbligaqzioni Commerciali. Napoli: Nicola Jovene, 1933.

LUONI, Sergio. Obbligazioni, Strumenti finanzieri, Titoli de Debito Nelle Società di Capitali. Diritto Commerciale direto da Gastone Cottino. Bolonha: Zanichelli, 2010.

MAJO, Adolfo di. Codice Civile. 32a ed. Milão: Giuffrè, 2012.

MANSON, Edward. The debentures and debenture stock of trading and other companies: with forms, including forms of proceedings to enforce securities. Legal Treatises, 1800-1926. $2^{a}$ ed. Londres: Butterworth Law Publishers, 1910. Reprodução do original da Biblioteca da Harvard Law School.

MARCHETTI, Piergaetano et. al. Commentario alla riforma delle società. Obbligazioni e Bilancio. A cura di Mario Notari e Luigi A. Bianchi. $1^{\text {a }}$ ed. Milão: Egea - Giuffrè, 2006.

MARKHAM, Jerry W.; GABILONDO, José M.; HAZEN; Thomas Lee. Corporate Finance. Debt, Equity, and Derivative Markets and their Intermediaries. $3^{\mathrm{a}}$ ed. St. Paul: West, 2008. 
MERLE, Philippe. Droit Commercial. Sociétés Commerciales. 11ª ed. Paris: Dalloz, 2007.

MORERA, Umberto et. al. Il Diritto delle Società. $4^{\mathrm{a}}$ ed. Mulino: Società editrice, 2012.

MOSCHETTI, Cesare Maria. Il Codice Marittimo del 1781 di Michele de Jorio per Il Regno di Napoli. Vol II. Nápoles: Giannini Editore, 1979.

PALMITER, Alan R. Securities Regulation. $3^{\mathrm{a}}$ ed. New York: Aspen Publishers, 2005.

PARKER, Philip M. Debentures Webster's Timeline History. 1600 - 2004. San Diego: ICON Group International, 2009.

PATRIARCA, Sergio. I titoli di debito della S.R.L. tra opportunità e problemi interpretativi. Quaderni di Banca, Borsa e Titoli di Credito. N. 23. Milão: Giuffré, 2005.

PIRES, Florisbela de Almeida. Código das Sociedades Comerciais Anotado. Coord.: CORDEIRO, António Menezes. 2a ed. Coimbra: Almedina, 2012.

PISANI, Luca. Le obbligazioni. In "Il Nuovo Diritto Delle Società". Liber Amicorum Gian Franco Campobasso. Organizadores: ABBADESSA, P.; e PORTALE, G.B. Vol. 1. Turim: UTET Giuridica, 2007.

RICH, E. E. Minutes of Hudson Bay Company. Vol. V. Londres: Hudson's Bay Record Society, 1942.

RIPERT, G.; ROBLOT, R., Traité de Droit Commercial. Les Sociétés Commerciales. 19a ed. Tomo 1. Vol. 2, sob a direção de GERMAIN, Michel e colaboração de MAGNIER, Véronique. Paris: L.G.D.J., 2009.

RODRIGUEZ, Luís Ângulo. La Financiácion de Empresas Mediante Tipos Especiales de Obligaciones. Zaragoza: Cometa, 1968.

ROPPO, Enzo. O Contrato. Coimbra: Almedina, 2009.

ROMANO, Roberta. Foundations of Corporate Law. Nova Iorque: Foundation Press, 1993.

SANTARELLI, Umberto. Mercanti e Società Tra Mercanti. $3^{\text {a }}$ ed. Turim: Giappichelli Editore, 1998.

SCHIOPPA, Antonio Padoa. Saggi di Storia Del Diritto Commerciale. Milão: LED, 2009. 
SIMONSON, Paul Frederick. A treatise on the law relating to debentures and debentures stock: issued by trading and public companies and by local authorities: with forms and precedents. Londres: E. Wilson, 1899. Reprodução do original da Biblioteca da Harvard Law School.

TRABUCCHI, Alberto. Instituzioni di Diritto Civile. 45ª ed. Pádua: Antonio Milani, 2012.

VIANDIER, Alain; COZIAN, Maurice; e DEBOISSY, Florence. Droit des Sociétés. 18 ed. Paris: Litec, 2005.

VIETTI, Michele. Nuova Società per un Nuovo Mercato. La Riforma delle Società Commerciali. Roma: Salerno, 2003.

VIVANTE, Cesare. Trattato di Diritto Commerciale. Vol. III. $4^{\mathrm{a}}$ ed. Milão: Francesco Vallardi, 1914.

WEBER, Max. The History of Commercial Partnerships in the Middle Ages. The first Complete English Edition of Weber's Prelude to The Protestant Ethic and the Spirit of Capitalism and Economy and Society. Oxford: Rowman \& Littlefield, 2003.

WICKER, Guillaume; DEBOISSY, Florence. Code des Societies et Autres Groupements. $6^{\mathrm{a}}$ ed. Paris: LexisNexis, 2012.

YOMHA, Carlos Gabriel. Obligaciones Convertibles en Acciones. Buenos Aires: Depalme, 1983.

\section{Obras e artigos em meio eletrônico}

AYUSO, Silvia et. al. Maximizing Stakeholders' Interests: An Empirical Analysis of the Stakeholder Approach to Corporate Governance. Working Paper N ${ }^{\circ}$ 670. IESE Business School, 2007. Disponível em: http://ssrn.com/abstract=982325. Acesso em: 31/08/2013.

BAINBRIDGE, Stephen M. In Defense of the Shareholder Wealth Maximization Norm. Washington \& Lee Law Review. Vol. 50, 1993, p. 1423. Disponível em: http://ssrn.com/abstract=303780. Acesso em: 09/08/2013.

BOOTH, Richard A. The Duty to Creditors Reconsidered - Filling a Much Needed Gap in Corporation Law. Legal Studies Research Paper No 2006-42. Universidade de Maryland, 2006. Disponível em: http://ssrn.com/abstract=886772. Acesso em: 31/08/2013.

Codice di Commercio del Regno D'Italia. Florença: Stamperia Reale, 1866. 
FELLONI, Giuseppe. Compere di San Giorgio. Disponível em: http://www.lacasadisangiorgio.it/main.php?do=node\&tag=4_4. Acesso em: 28/08/2013.

La casa delle Compere e dei Banchi di San Giorgio. Debito Pubblico. Disponível em: http://www.lacasadisangiorgio.it/main.php?do=node\&tag=4_4. Acesso em: 28/08/2013.

HANSMANN, Henry; KRAAKMAN, Reinier. The End of History For Corporate Law. Working Paper $\mathrm{N}^{\mathrm{o}}$ 235. Yale Law School, 2000, pp. 2-3. Disponível em: http://ssrn.com/abstract=204528. Acesso em: 09/08/2013.

HODGES, James. Londres: E. and R. Nutt, and R. Gosling, 1740. Disponível em: http://find.galegroup.com/ecco. Acesso em 25/01/2013.

LIPSON, Jonathan C. The Expressive Function of Directors' Duties to Creditors. Stanford Journal of Law, Business and Finance. Vol. 12. № 2. Stanford University, 2007. Disponível em: http://ssrn.com/abstract=988798. Acesso em 31/08/2013.

MALUF, Luiz Rafael de Vargas. Renda Fixa Ganha "Novo Mercado". In: Revista Capital Aberto. Ano 8. $\mathrm{N}^{\mathrm{o}}$ 93. Maio, 2011. Disponível em: http://www.capitalaberto.com.br/ler_artigo.php?pag=2\&sec=121\&i=3950. Acesso em: 03/08/2013.

Other Constituencies Statutes: Potential for Confusion. Revista The Business Lawyer. Vol. 45. $\mathrm{N}^{\mathrm{o}}$ 4. American Bar Association, 1990. Disponível em: http://www.jstor.org/stable/40687148. Acesso em: 09/08/2013.

PIMENTEL, Renê Coppe; PERES, Edna Ferreira; LIMA, Gerlando Augusto Sampaio Franco de. O mercado de Debêntures e o Financiamento Produtivo no Brasil: uma Análise de Cointegração e Causalidade. Revista de Contabilidade e Organizações, da Faculdade de Economia, Administração e Contabilidade da Universidade de São Paulo. Vol. 5. N. 11, Ano 2011. Disponível em: www.rco.usp.br/index.php/rco/article/download/155/190. Acesso em: 21/08/2013.

SANTOS, Theophilo de Azeredo. Commercial Paper, Export Notes - Endossador NãoResponsável pelo Título de Crédito. Disponível em: http://daleth.cjf.jus.br/revista/seriecadernos/VOL16-7.htm. Acesso em: 18/04/2013.

SAPPIDEEN, Razeen. Fiduciary Obligations to Corporate Creditors. Journal of Business Law, 2009, pp. 365-397. Disponível em: http://ssrn.com/abstract=1464572. Acesso em: $31 / 08 / 2013$.

SCHÖN, Wolfgang et al. Debt and Equity: What's the difference? A Comparative View. Max Planck Institute for Intellectual Property, Competition \& Tax Law. Research Paper $\mathrm{n}^{\circ}$ 09-09. Disponível em: http://ssrn.com/abstract=1457649. Acesso em: 18 junho 2012. 
SEPE, Simone M. Directors' Duty to Creditors and the Debt Contract. Journal of Business \& Technology Law. Vol. 1. $\mathrm{N}^{\mathrm{o}}$ 2, 2007. Disponível em: http://ssrn.com/abstract=1086139. Acesso em: 31/08/2013.

STEEL, Anthony. The Negotiation of Wardrobe Debentures. In: The Fourteenth Century in the English Historical Review. Vol. 44. No 175. Oxford University Press, 1929. Artigo disponível em: http://www.jstor.org/stable/553042. Acesso em 25/01/2013.

Teses, dissertações, artigos e matérias jornalísticas

BESSEMBINDER, Hendrik; MAXWELL, William. Markets: Transparency and the Corporate Bond Market. The Journal of Economic Perspectives. Vol. 22. $\mathrm{N}^{\mathrm{o}}$ 2. American Economic Association, 2008.

BORGES, Luiz Ferreira Xavier. Securitização como parte da Segregação de Risco. Revista do BNDES. V. 6. N. 12. Rio de Janeiro: BNDES, 1999.

CARO, Luciana Del. Títulos aditivados: entidades criam o Novo Mercado de Renda Fixa, a mais recente cartada a favor da divida privada. Revista Capital Aberto. Edição nº 93, 2011.

Estudos especiais: SND - Sistema Nacional de Debêntures. Rio de Janeiro: ANDIMA, 1998.

IUDÍCIBUS, Sergio; RICARDINO FILHO, Álvaro Augusto. A Primeira Lei das Sociedades Anônimas no Brasil. Lei $n^{o} 1.083$ - 22 de agosto de 1860. Revista de Contabilidade e Finanças. № 29. Universidade de São Paulo, 2002.

JELONCHE, Edgar. Mercosur y Valores Mobiliarios. In: Simpósio sobre Direito dos Valores Mobiliários. Série Cadernos do Conselho da Justiça Federal. N. 16. Brasília: CJF, 1999.

LANDES, David S.; MOKYR, Joel; BAUMOL, William. The Invention of Enterprise. Princeton: Princeton University Press, 2010.

LIMA, Marcelle Fonseca; ROCHA, João Luiz Coelho da. Os Valores Mobiliários como Título de Crédito. Revista de Direito Mercantil, Industrial, Econômico e Financeiro. Ano XXXIX. Nova Série. No 119. São Paulo: Malheiros, 2000.

LORIA, Eli. Companhia aberta: objeto social e operações de risco. Tese de Doutorado apresentada à Faculdade de Direito da Universidade de São Paulo, 2012.

MATTOS FILHO, Ary Osvaldo. O Conceito de Valor Mobiliário. Revista de Direito Mercantil, Industrial, Econômico e Financeiro. Ano XXIV. Nova Série. N ${ }^{\circ}$ 59. São Paulo: RT, 1985. 
MENDES, Octavio. Da Posição Jurídica do Debenturista em Face da Falência. Dissertação de Mestrado apresentada à Faculdade de Direito da Universidade de São Paulo, 1919.

PEREIRA NETO, Edmur de Andrade Nunes. Aspectos Jurídicos da Emissão de Debêntures Conversíveis em Ações. Dissertação de Mestrado apresentada à Faculdade de Direito da Universidade de São Paulo, 1986.

PINTO JÚNIOR, Mario Engler. Debêntures. Direitos dos Debenturistas - Comunhão e Assembleia - Agente Fiduciário. Revista dos Tribunais. Ano 72. Vol. 567. São Paulo: RT, 1983.

SALLES, Marcos Paulo de A. Uma Contribuição à Análise das Debêntures. Dissertação de Mestrado apresentada à Faculdade de Direito da Universidade de São Paulo, 1986.

SZTAJN, Rachel. Conceito de Liquidez na Disciplina do Mercado de Valores Mobiliários. Revista de Direito Mercantil, Industrial, Econômico e Financeiro. Ano XLI. Nova Série. No 126. São Paulo: Malheiros, 2002.

WALD, Arnold. Da aquisição, por instituições financeiras, de debêntures emitidas por empresas de arrendamento mercantil que sejam suas controladas. Interpretação da Lei 6.099/74 e da regulamentação do Conselho Monetário Nacional sobre a matéria. Não configuração de ilicitude administrativa ou penal". Revista de Direito Bancário e do Mercado de Capitais. Ano 12. No 43. São Paulo: RT, 2009. 